Prepared in cooperation with the California State Water Resources Control Board A product of the California Groundwater Ambient Monitoring and Assessment (GAMA) Program

\title{
Status and Understanding of Groundwater Quality in the North San Francisco Bay Shallow Aquifer Study Unit, 2012: California GAMA Priority Basin Project
}

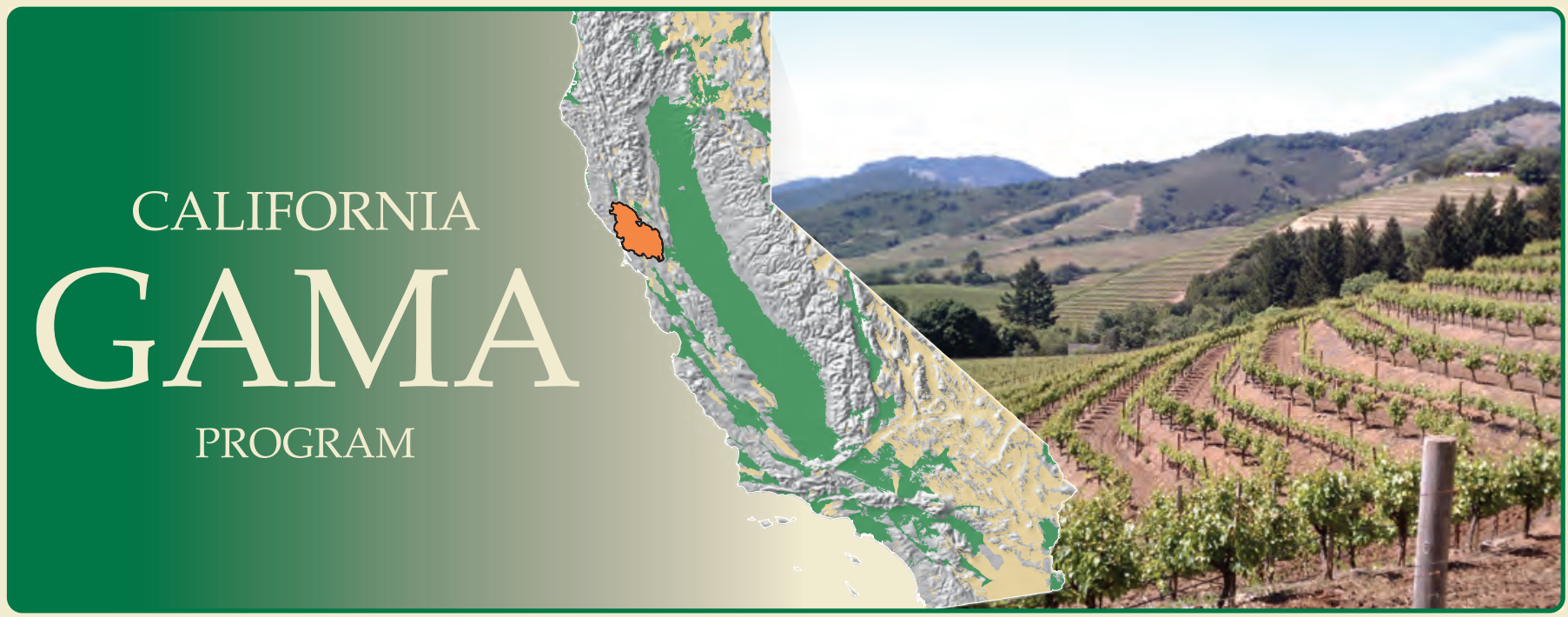

Scientific Investigations Report 2017-5051

Version 1.1, February 2018 


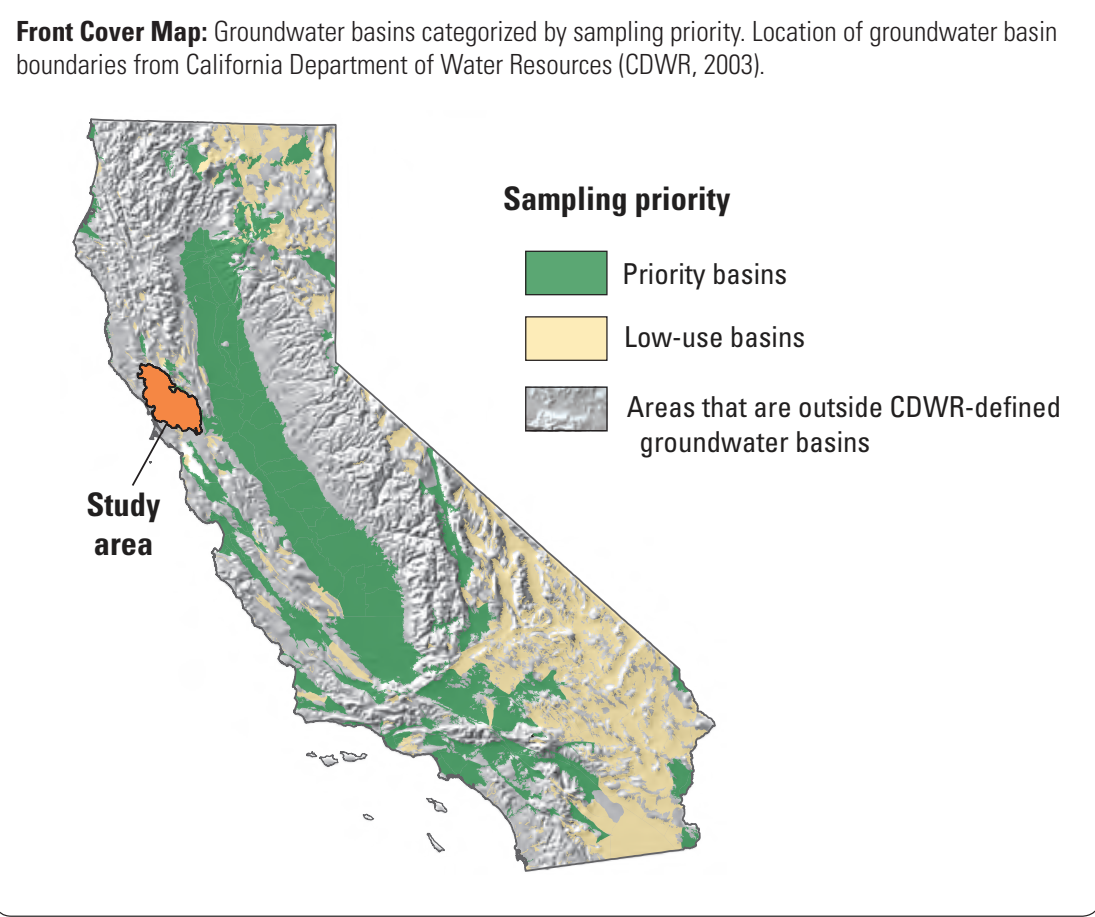

\section{Cover photographs:}

Front cover: Scenic photograph near Petaluma, California. (Photograph taken by George Bennett, U.S. Geological Survey).

Back cover: Jennifer Shelton (U.S. Geological Survey employee) canvassing a well near Middletown, California. (Photograph taken by Antonia Salas, U.S. Geological Survey). 


\section{Status and Understanding of Groundwater Quality in the North San Francisco Bay Shallow Aquifer Study Unit, 2012: California GAMA Priority Basin Project}

By George L. Bennett, V

A product of the California Groundwater Ambient Monitoring and Assessment (GAMA) Program

Prepared in cooperation with the California State Water Resources Control Board

Scientific Investigations Report 2017-5051

Version 1.1, February 2018 


\title{
U.S. Department of the Interior \\ RYAN K. ZINKE, Secretary
}

\section{U.S. Geological Survey William H. Werkheiser, Acting Director}

\author{
U.S. Geological Survey, Reston, Virginia: 2017 \\ First release: 2017 \\ Revised: February 2018 (ver. 1.1)
}

\begin{abstract}
For more information on the USGS - the Federal source for science about the Earth, its natural and living resources, natural hazards, and the environment—visit http://www.usgs.gov or call 1-888-ASK-USGS.

For an overview of USGS information products, including maps, imagery, and publications, visit http://www.usgs.gov/pubprod/.
\end{abstract}

\author{
Any use of trade, firm, or product names is for descriptive purposes only and does not imply endorsement by the \\ U.S. Government. \\ Although this information product, for the most part, is in the public domain, it also may contain copyrighted materials \\ as noted in the text. Permission to reproduce copyrighted items must be secured from the copyright owner. \\ Suggested citation: \\ Bennett, G.L., V, 2018, Status and understanding of groundwater quality in the North San Francisco Bay Shallow \\ Aquifer study unit, 2012; California GAMA Priority Basin Project (ver. 1.1, February 2018): U.S. Geological Survey \\ Scientific Investigations Report 2017-5051, 74 p., https://doi.org/10.3133/sir20175051. \\ ISSN 2328-0328 (online)
}




\section{Acknowledgments}

We especially thank the site owners and water purveyors for granting access to wells, allowing the U.S. Geological Survey to collect samples from their sites. Most of the funding for this work was provided by State of California bonds authorized by Proposition 50 and administered by the California State Water Resources Control Board. Additional funding was provided by the U.S. Geological Survey Cooperative Matching Funds. This report is a product of the California State Water Resources Control Board Groundwater Ambient Monitoring and Assessment Program Priority Basin Project.

\section{Contents}

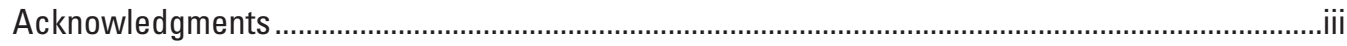

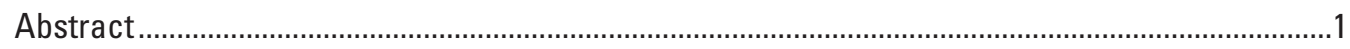

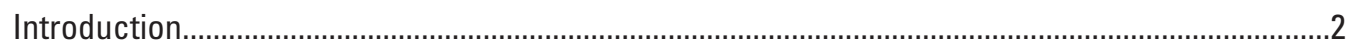

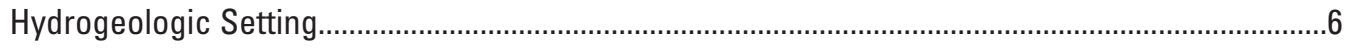

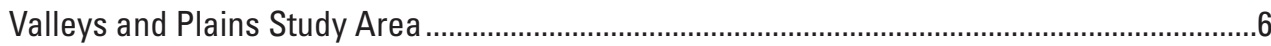

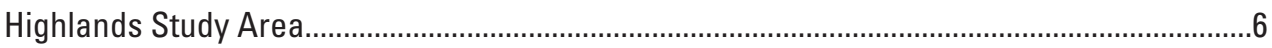

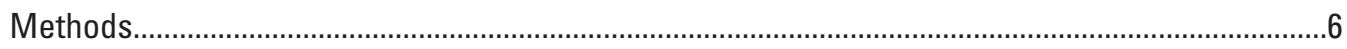

Status Assessment ...........................................................................................................

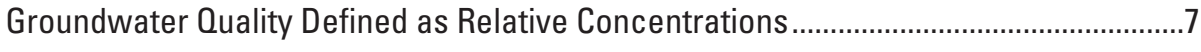

Dataset Used for Status Assessment...........................................................................

Selection of Constituents for Discussion.....................................................................

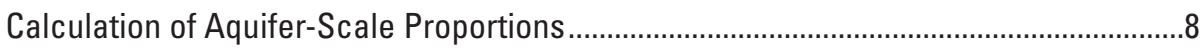

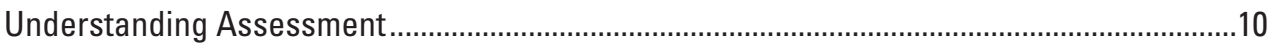

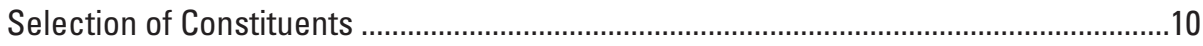

Statistical Analysis .............................................................................................. 10

Comparison Between NSF-SA and NSF-PA ....................................................................11

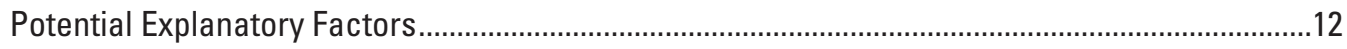

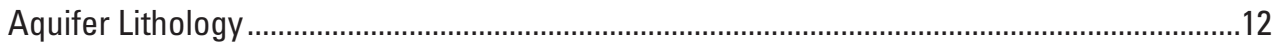

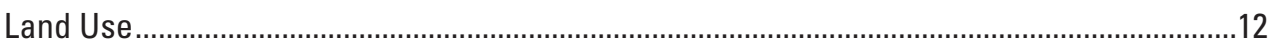

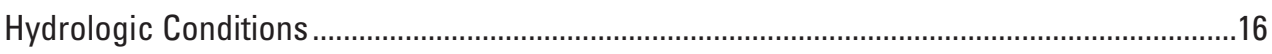

Depth and Groundwater Age Characteristics of the Shallow Aquifer System ........................16

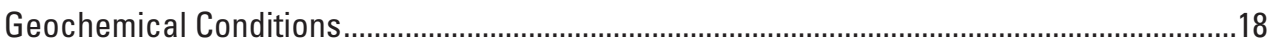

Status and Understanding of Groundwater Quality in the Shallow Aquifer System ........................18

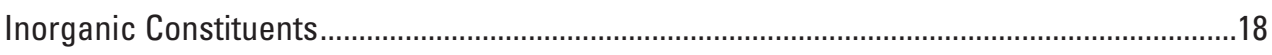

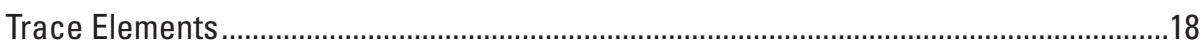

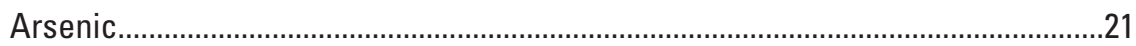

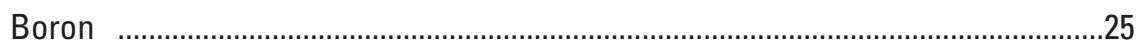

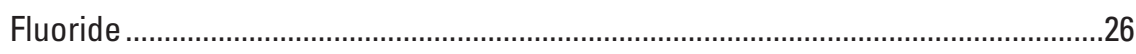

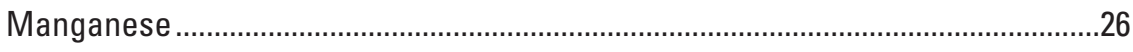

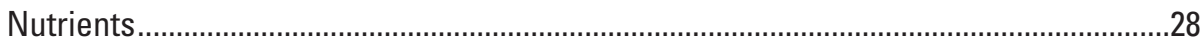

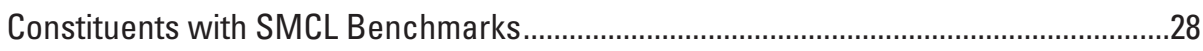

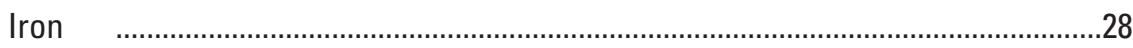




\section{Contents-Continued}

Total Dissolved Solids, Chloride, and Sulfate ............................................................28

Organic and Special-Interest Constituents ..........................................................................

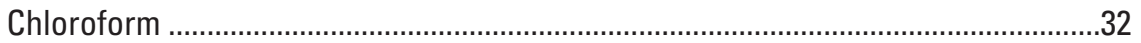

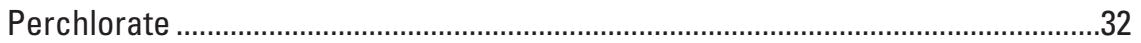

Comparison of Shallow and Public-Supply Aquifer Systems ..........................................................34

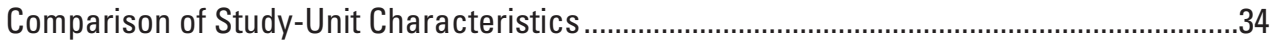

Well-Construction Comparison ...................................................................................

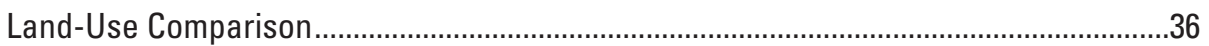

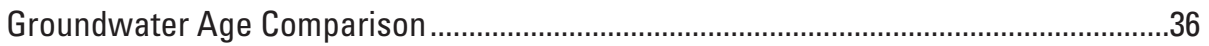

General Chemical Composition Comparison...................................................................38

Geochemical Condition Comparison ................................................................................38

Comparison of Water Quality...............................................................................................38

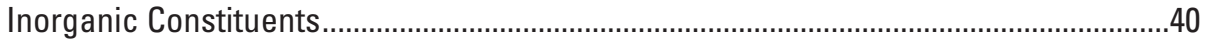

Organic and Special-Interest Constituents ...................................................................40

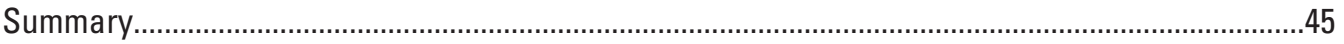

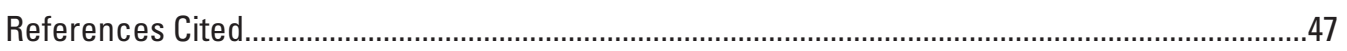

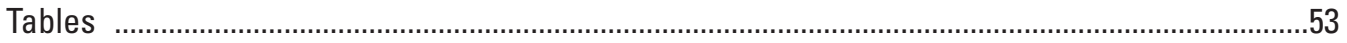

Appendix 1. Attribution of Potential Explanatory Factors ………...................................................63

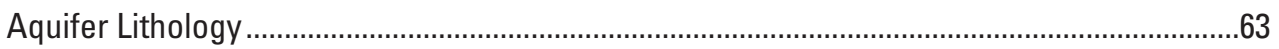

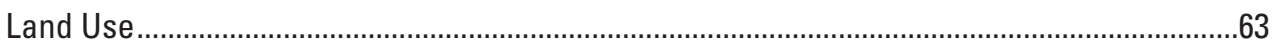

Underground Storage Tank and Septic Tank Densities.........................................................63

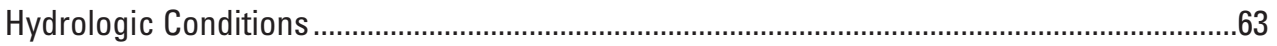

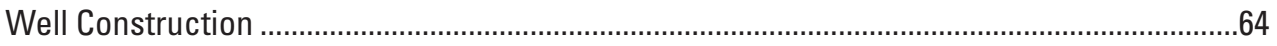

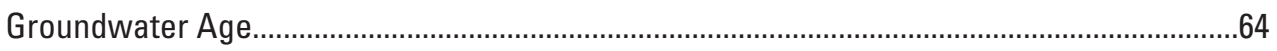

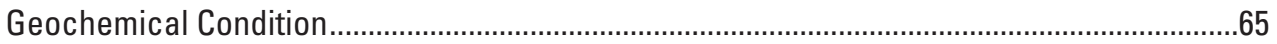

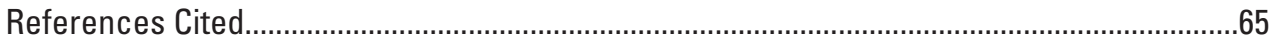

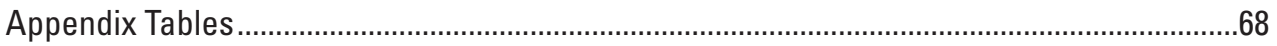

\section{Figures}

1. Map showing hydrogeologic provinces of California and the location of the North San Francisco Bay Shallow Aquifer study unit, 2012, California Groundwater Ambient Monitoring and Assessment Program Priority Basin Project.

2. Map showing location and boundaries of the North San Francisco Bay Shallow Aquifer study unit, the Public-Supply Aquifer study unit, and the Highlands and Valleys and Plains study areas.

3. Map showing locations of grid cells, groundwater grid sites, and the extra site sampled for the North San Francisco Bay Shallow Aquifer study unit, 2012, California Groundwater Ambient Monitoring and Assessment Program Priority Basin Project

4. Generalized geologic map showing surficial lithologic categories of the North San Francisco Bay Shallow Aquifer study unit, California Groundwater Ambient Monitoring and Assessment Program Priority Basin Project. 


\section{Figures-Continued}

5. Ternary diagrams showing land use of the North San Francisco Bay Shallow Aquifer study unit for 2011, California Groundwater Ambient Monitoring and Assessment Program Priority Basin Project..

6. Map showing 2011 land use and locations of groundwater sites in the North San Francisco Bay Shallow Aquifer study unit, sampled in 2012, California Groundwater Ambient Monitoring and Assessment Program Priority Basin Project.

7. Box plots showing well depth and depth to top of perforation for U.S. Geological Survey sampled grid wells, North San Francisco Bay Shallow Aquifer study unit, 2012, California Groundwater Ambient Monitoring and Assessment Program Priority Basin Project.

8. Box plots showing summaries of groundwater classified as modern, mixed, or premodern in age, North San Francisco Bay Shallow Aquifer study unit, 2012, California Groundwater Ambient Monitoring and Assessment Program Priority Basin Project, by well depth and depth to top of screened or open interval for wells.

9. Graph showing maximum relative concentrations for constituents detected in U.S. Geological Survey grid sites by type of constituent, North San Francisco Bay Shallow Aquifer study unit, 2012, California Groundwater Ambient Monitoring and Assessment Program Priority Basin Project.

10. Dot plots showing relative concentrations of selected constituent classes in samples from U.S. Geological Survey grid sites, North San Francisco Bay Shallow Aquifer study unit, 2012, California Groundwater Ambient Monitoring and Assessment Program Priority Basin Project.

11. Maps showing relative concentrations of selected trace elements in samples from U.S. Geological Survey grid sites, North San Francisco Bay Shallow Aquifer study unit, 2012, California Groundwater Ambient Monitoring and Assessment Program Priority Basin Project.

12. Graph showing relation of arsenic concentration to dissolved oxygen concentration and groundwater age class, North San Francisco Bay Shallow Aquifer study unit, 2012, California Groundwater Ambient Monitoring and Assessment Program Priority Basin Project.

13. Trilinear diagrams showing relative ionic composition, water types, and groundwater age classifications in U.S. Geological Survey grid sites, North San Francisco Bay Shallow Aquifer study unit, 2012, California Groundwater Ambient Monitoring and Assessment Program Priority Basin Project.

14. Map showing relative concentrations of nitrate in samples from U.S. Geological Survey grid sites, North San Francisco Bay Shallow Aquifer study unit, 2012, California Groundwater Ambient Monitoring and Assessment Program Priority Basin Project.

15. Graph showing detection frequency and maximum relative concentration of organic and special-interest constituents detected in samples from U.S. Geological Survey grid sites, North San Francisco Bay Shallow Aquifer study unit, 2012, California Groundwater Ambient Monitoring and Assessment Program Priority Basin Project.

16. Graphs showing relative concentrations of selected organic and special-interest constituents in samples from U.S. Geological Survey grid sites, North San Francisco Bay Shallow Aquifer study unit, 2012, California Groundwater Ambient Monitoring and Assessment Program Priority Basin Project.. 


\section{Figures-Continued}

17. Graph showing predicted probability under natural conditions of detecting perchlorate in groundwater as a function of aridity index and observed detection frequency and average aridity index grouped by specified threshold values, North San Francisco Bay Shallow Aquifer study unit, 2012, California Groundwater Ambient Monitoring and Assessment Program Priority Basin Project.

18. Map comparing study area extents of the Public-Supply Aquifer study unit and Shallow Aquifer study unit, North San Francisco Bay, California Groundwater Ambient Monitoring and Assessment Program Priority Basin Project

19. Box plots summarizing well depths by study area for North San Francisco Bay Public-Supply Aquifer study unit and Shallow Aquifer study unit, California Groundwater Ambient Monitoring and Assessment Program Priority Basin Project ....36

20. Diagrams summarizing 2011 land use by study area, as the average percentage by land-use category of circular area within 500 meters of sampled sites, for North San Francisco Bay Public-Supply Aquifer study unit and Shallow Aquifer study unit, California Groundwater Ambient Monitoring and Assessment Program Priority Basin Project

21. Diagrams summarizing groundwater age-dating sampling results in the Highlands and Valleys and Plains study areas of the North San Francisco Bay Public-Supply Aquifer study unit, sampled 2004, and the Shallow Aquifer study unit, sampled 2012, California Groundwater Ambient Monitoring and Assessment Program Priority Basin Project.

22. Graphs showing chemical ionic composition of groundwater in samples from sites in the North San Francisco Bay Public-Supply Aquifer study unit, 2004, and Shallow Aquifer study unit, 2012, California Groundwater Ambient Monitoring and Assessment Program Priority Basin Project.

23. Boxplots summarizing $\mathrm{pH}$ values in samples from the North San Francisco Bay Public-Supply Aquifer study unit, 2004, and Shallow Aquifer study unit, 2012, California Groundwater Ambient Monitoring and Assessment Program Priority Basin Project

24. Graphs summarizing by study unit and study area the proportions of samples with high, moderate, and low relative concentrations for any inorganic constituent with health-based benchmarks as a group, North San Francisco Bay Public-Supply Aquifer study unit, sampled in 2004, and Shallow Aquifer study unit, sampled in 2012, California Groundwater Ambient Monitoring and Assessment Program Priority Basin Project

25. Graphs summarizing by study unit and study area the proportions of samples with high, moderate, and low relative concentrations for trace elements with healthbased benchmarks as a group, North San Francisco Bay Public-Supply Aquifer study unit, sampled in 2004, and Shallow Aquifer study unit, sampled in 2012, California Groundwater Ambient Monitoring and Assessment Program Priority Basin Project ....41

26. Graphs summarizing by study unit and study area the proportions of samples with high, moderate, and low relative concentrations, North San Francisco Bay PublicSupply Aquifer study unit, sampled in 2004, and Shallow Aquifer study unit, sampled in 2012, California Groundwater Ambient Monitoring and Assessment Program Priority Basin Project for nitrate, arsenic, and manganese 


\section{Figures-Continued}

27. Graphs summarizing by study unit and study area the proportions of samples with high, moderate, and low relative concentrations of inorganic constituents with aestheticbased secondary maximum contaminant levels by constituent class, in the North San Francisco Bay Public-Supply Aquifer study unit and Shallow Aquifer study unit and their study areas, 2012, California Groundwater Ambient Monitoring and Assessment Program Priority Basin Project, for any inorganic constituent, trace elements, and major ions and total dissolved solids.

28. Graphs summarizing by study unit and study area the proportions of samples with high, moderate, and low relative concentrations and non-detections for organic constituents with health-based benchmarks as a group, North San Francisco Bay Public-Supply Aquifer study unit, sampled in 2004, and Shallow Aquifer study unit, sampled in 2012, California Groundwater Ambient Monitoring and Assessment Program Priority Basin Project.

29. Diagrams showing detection frequency by study area of organic constituent classes in the North San Francisco Bay Public-Supply Aquifer study unit, sampled 2004, and Shallow Aquifer study unit, sampled 2012, California Groundwater Ambient Monitoring and Assessment Program Priority Basin Project.

30. Graphs summarizing by study unit and study area the proportions of samples with moderate and low relative concentrations and non-detections of perchlorate in the North San Francisco Bay Public-Supply Aquifer study unit, sampled in 2004, and Shallow Aquifer study unit, sampled in 2012, California Groundwater Ambient Monitoring and Assessment Program Priority Basin Project.

\section{Tables}

1. Summary of groundwater sites, water-quality constituent groups, and numbers of constituents sampled for each constituent group by the U.S. Geological Survey in the North San Francisco Bay Shallow Aquifer study unit, 2012, California Groundwater Ambient Monitoring and Assessment Program Priority Basin Project..

2. Benchmark type and value for water-quality constituents present at high or moderate relative concentrations in samples from grid sites and for organic constituents present at any concentration in more than 10 percent of samples from the North San Francisco Bay Shallow Aquifer study unit, 2012, California Groundwater Ambient Monitoring and Assessment Program Priority Basin Project ....54

3. Benchmark type and value for water-quality constituents present only at low relative concentrations or lacking benchmarks and detected in samples collected for the North San Francisco Bay Shallow Aquifer study unit, 2012, California Groundwater Ambient Monitoring and Assessment Program Priority Basin Project ....55

4. Results of Kruskal-Wallis and Wilcoxon rank-sum tests for differences in values of land-use factors, hydrologic conditions, geochemical conditions, and selected waterquality constituents between samples classified into groups on the basis of aquifer lithology, age of groundwater, redox condition, or study area, North San Francisco Bay Shallow Aquifer study unit, 2012, California Groundwater Ambient Monitoring and Assessment Program Priority Basin Project. 


\section{Tables-Continued}

5. Results of tests of significance of Spearman's rho $(\rho)$ coefficient of rank correlation between selected potential explanatory factors and selected water-quality constituents, North San Francisco Bay Shallow Aquifer study unit 2012, California Groundwater Ambient Monitoring and Assessment Program Priority Basin Project ....58

$6 A$. Summary of aquifer-scale proportions in the North San Francisco Bay Shallow Aquifer study unit, 2012, California Groundwater Ambient Monitoring and Assessment Program Priority Basin Project for inorganic constituent classes with healthbased and aesthetic-based benchmarks

6B. Summary of aquifer-scale proportions in the North San Francisco Bay Shallow Aquifer study unit, 2012, California Groundwater Ambient Monitoring and Assessment Program Priority Basin Project for organic and special-interest constituent classes with health-based benchmarks.

7. Aquifer-scale proportions, summarized for study unit and study areas, of the assessed groundwater resource with high and moderate relative concentrations of constituents selected for additional evaluation, status assessment, North San Francisco Bay Shallow Aquifer study unit, 2012, California Groundwater Ambient Monitoring and Assessment Program Priority Basin Project.

8. Results from testing significance of Spearman's rho ( $\rho$ ) coefficient of rank-order correlations between selected potential explanatory factors and selected waterquality constituents, North San Francisco Bay Shallow Aquifer study unit, 2012, California Groundwater Ambient Monitoring and Assessment Program Priority Basin Project

9. Results from testing significance of Spearman's rho $(\rho)$ coefficient of rank-order correlations between selected water-quality constituents, North San Francisco Bay Shallow Aquifer study unit, 2012, California Groundwater Ambient Monitoring and Assessment Program Priority Basin Project.

1-1. Site-specific data for aquifer lithology class, land use, hydrologic conditions, underground storage tank density, and septic tank density, North San Francisco Bay Shallow Aquifer study unit, 2012, California Groundwater Ambient Monitoring and Assessment Program Priority Basin Project.

1-2. Site construction information for U.S. Geological Survey sampled grid sites and extra site, North San Francisco Bay Shallow Aquifer study unit, 2012, California Groundwater Ambient Monitoring and Assessment Program Priority Basin Project ....70

1-3. Tritium and carbon-14 data and groundwater age class, North San Francisco Bay Shallow Aquifer study unit, 2012, California Groundwater Ambient Monitoring and Assessment Program Priority Basin Project.

1-4. Oxidation-reduction class, dissolved oxygen concentration, and $\mathrm{pH}$ for U.S. Geological Survey (USGS) grid sites and the USGS extra site, North San Francisco Bay Shallow Aquifer study unit, 2012, California Groundwater Ambient Monitoring and Assessment Program Priority Basin Project.

1-5. Oxidation-reduction classification system applied to U.S. Geological Survey (USGS) grid sites and the USGS extra site, North San Francisco Bay Shallow Aquifer study unit, 2012, California Groundwater Ambient Monitoring and Assessment Program Priority Basin Project 


\section{Conversion Factors}

International System of Units to U.S. customary units

\begin{tabular}{|c|c|c|}
\hline Multiply & By & To obtain \\
\hline \multicolumn{3}{|c|}{ Length } \\
\hline centimeter $(\mathrm{cm})$ & 0.3937 & inch (in.) \\
\hline millimeter (mm) & 0.03937 & inch (in.) \\
\hline meter (m) & 3.281 & foot $(\mathrm{ft})$ \\
\hline kilometer (km) & 0.6214 & mile (mi) \\
\hline \multicolumn{3}{|c|}{ Area } \\
\hline square meter $\left(\mathrm{m}^{2}\right)$ & 10.76 & square foot $\left(\mathrm{ft}^{2}\right)$ \\
\hline square kilometer $\left(\mathrm{km}^{2}\right)$ & 0.3861 & square mile $\left(\mathrm{mi}^{2}\right)$ \\
\hline \multicolumn{3}{|c|}{ Volume } \\
\hline liter (L) & 1.057 & quart $(\mathrm{qt})$ \\
\hline
\end{tabular}

Temperature in degrees Celsius $\left({ }^{\circ} \mathrm{C}\right)$ may be converted to degrees Fahrenheit $\left({ }^{\circ} \mathrm{F}\right)$ as follows:

$$
{ }^{\circ} \mathrm{F}=\left(1.8 \times{ }^{\circ} \mathrm{C}\right)+32 \text {. }
$$

Temperature in degrees Fahrenheit $\left({ }^{\circ} \mathrm{F}\right)$ may be converted to degrees Celsius $\left({ }^{\circ} \mathrm{C}\right)$ as follows:

$$
{ }^{\circ} \mathrm{C}=\left({ }^{\circ} \mathrm{F}-32\right) / 1.8 \text {. }
$$

\section{Datum}

Vertical coordinate information is referenced to the North American Vertical Datum of 1988 (NAVD 88). Land-surface datum (LSD), as used in this report, refers to a horizontal plane that is approximately at land surface at each site, at a specific elevation relative to NAVD 88.

Horizontal coordinate information is referenced to the North American Datum of 1983 (NAD 83).

\section{Supplemental Information}

Specific conductance is given in microsiemens per centimeter at 25 degrees Celsius $(\mu \mathrm{S} / \mathrm{cm}$ at $\left.25^{\circ} \mathrm{C}\right)$.

Concentrations of chemical constituents in water are given either in milligrams per liter (mg/L) or micrograms per liter ( $\mu \mathrm{g} / \mathrm{L})$ or nanograms per liter $(\mathrm{ng} / \mathrm{L})$. One milligram per liter is equivalent to 1 part per million (ppm); 1 microgram per liter is equivalent to 1 part per billion (ppb); 1 nanogram per liter (ng/L) is equivalent to 1 part per trillion (ppt); 1 per mil is equivalent to 1 part per thousand.

Activities for radioactive constituents in water are given in picocuries per liter (pCi/L).

Concentrations of tritium are presented in tritium units (TU). One TU equals $3.19 \mathrm{pCi} / \mathrm{L}$. 


\section{Abbreviations}

\begin{tabular}{|c|c|}
\hline${ }^{14} \mathrm{C}$ & carbon-14 \\
\hline AL-US & U.S. Environmental Protection Agency action level \\
\hline BO & benchmark quotient \\
\hline CDWR & California Department of Water Resources \\
\hline DDW & California State Water Resources Control Board Division of Drinking Water \\
\hline DO & dissolved oxygen \\
\hline EPA & U.S. Environmental Protection Agency \\
\hline GAMA & Groundwater Ambient Monitoring and Assessment Program \\
\hline GAMA-PBP & GAMA Priority Basin Project \\
\hline HAL-US & U.S. Environmental Protection Agency lifetime health advisory level \\
\hline HBSL & Health-based screening level \\
\hline LSD & land-surface datum \\
\hline LLNL & Lawrence Livermore National Laboratory \\
\hline MCL & maximum contaminant level \\
\hline MCL-CA & $\begin{array}{l}\text { California State Water Resources Control Board Division of Drinking Water } \\
\text { maximum contaminant level }\end{array}$ \\
\hline MCL-US & U.S. Environmental Protection Agency maximum contaminant level \\
\hline NAVD 88 & North American Vertical Datum of 1988 \\
\hline NAWQA & National Water Quality Assessment \\
\hline $\mathrm{NL}-\mathrm{CA}$ & $\begin{array}{l}\text { California State Water Resources Control Board Division of Drinking Water } \\
\text { notification level }\end{array}$ \\
\hline NSF-PA & North San Francisco Bay Public-Supply Aquifer study unit \\
\hline NSF-SA & North San Francisco Bay Shallow Aquifer study unit \\
\hline $\mathrm{pmC}$ & percent modern carbon \\
\hline $\mathrm{RC}$ & relative concentration \\
\hline RSD5-US & U.S. Environmental Protection Agency risk-specific dose at a risk factor of $10^{-5}$ \\
\hline SIR & Scientific Investigations Report \\
\hline SMCL-CA & $\begin{array}{l}\text { California State Water Resources Control Board Division of Drinking Water } \\
\text { secondary maximum contaminant level }\end{array}$ \\
\hline SMCL-US & U.S. Environmental Protection Agency secondary maximum contaminant level \\
\hline SWRCB & California State Water Resources Control Board \\
\hline TDS & total dissolved solids \\
\hline TEAP & terminal electron acceptor process \\
\hline THM & trihalomethane \\
\hline TT-US & EPA treatment technique level \\
\hline TU & tritium unit \\
\hline USGS & U.S. Geological Survey \\
\hline UST & underground storage tank \\
\hline VOC & volatile organic compound \\
\hline WCR & well completion report \\
\hline $\mathrm{yr}$ & year \\
\hline
\end{tabular}




\title{
Status and Understanding of Groundwater Quality in the North San Francisco Bay Shallow Aquifer Study Unit, 2012: California GAMA Priority Basin Project
}

\author{
By George L. Bennett, V
}

\section{Abstract}

Groundwater quality in the North San Francisco Bay Shallow Aquifer study unit (NSF-SA) was investigated as part of the Priority Basin Project of the California Groundwater Ambient Monitoring and Assessment (GAMA) Program. The study unit is in Marin, Mendocino, Napa, Solano, and Sonoma Counties and included two physiographic study areas: the Valleys and Plains area and the surrounding Highlands area. The NSF-SA focused on groundwater resources used for domestic drinking water supply, which generally correspond to shallower parts of aquifer systems than that of groundwater resources used for public drinking water supply in the same area. The assessments characterized the quality of untreated groundwater, not the quality of drinking water.

This study included three components: (1) a status assessment, which characterized the status of the quality of the groundwater resources used for domestic supply for 2012; (2) an understanding assessment, which evaluated the natural and human factors potentially affecting water quality in those resources; and (3) a comparison between the groundwater resources used for domestic supply and those used for public supply.

The status assessment was based on data collected from 71 sites sampled by the U.S. Geological Survey for the GAMA Priority Basin Project in 2012. To provide context, concentrations of constituents measured in groundwater were compared to U.S. Environmental Protection Agency (EPA) and California State Water Resources Control Board Division of Drinking Water regulatory and non-regulatory benchmarks for drinking-water quality. The status assessment used a gridbased method to estimate the proportion of the groundwater resources that has concentrations of water-quality constituents approaching or above benchmark concentrations. This method provides statistically unbiased results at the study-area scale and permits comparisons to other GAMA Priority Basin Project study areas.
In the NSF-SA study unit as a whole, inorganic constituents with human-health benchmarks were detected at high relative concentrations (RCs) in 27 percent of the shallow aquifer system, and inorganic constituents with secondary maximum contaminant levels (SMCL) were detected at high RCs in 24 percent of the system. The inorganic constituents detected at high RCs were arsenic, boron, fluoride, manganese, nitrate, iron, sulfate, and total dissolved solids (TDS). Organic constituents with human-health benchmarks were detected at high RCs in 1 percent of the shallow aquifer system. Of the 148 organic constituents analyzed, 30 constituents were detected, although only 1 , chloroform, had a detection frequency greater than 10 percent.

Natural and anthropogenic factors that could affect the groundwater quality were evaluated by using results from statistical testing of associations between constituent concentrations and values of potential explanatory factors. Groundwater age class (modern, mixed, or pre-modern), redox class (oxic or anoxic), aquifer lithology class (metamorphic, sedimentary, or volcanic), and dissolved oxygen concentrations were the explanatory factors that explained distribution patterns of most of the inorganic constituents best. Groundwater classified primarily as pre-modern or mixed in age was associated with higher concentrations of arsenic and fluoride than waters classified as modern. Anoxic or mixed redox conditions were associated with higher concentrations of boron, fluoride, and manganese. Similar patterns of association with explanatory variables were seen for inorganic constituents with aesthetic-based benchmarks detected at high concentrations. Nitrate and perchlorate had higher concentrations in oxic than in the anoxic redox class and were positively correlated with urban land use.

The NSF-SA water-quality results were compared to those of the GAMA North San Francisco Bay Public-Supply Aquifer study unit (NSF-PA). The NSF-PA was sampled in 2004 and covers much of the same area as the NSF-SA, but focused on the deeper public-supply aquifer system. 
The comparison of the NSF-PA to the NSF-SA showed that there were more differences between the Valleys and Plains study areas of the two study units than between the Highlands study areas of the two study units. As expected from the shallower depth of wells, the NSF-SA Valleys and Plains study area had a lesser proportion of pre-modern age groundwater and greater proportion of modern age groundwater than the NSF-PA Valleys and Plains study area. In contrast, well depths and groundwater ages were not significantly different between the two Highlands study areas. Arsenic, manganese, and nitrate were present at high RCs, and perchlorate was detected in greater proportions of the NSF-SA Valleys and Plains study area than the NSF-PA Valleys and Plains study area.

\section{Introduction}

Groundwater can supply approximately half of the water used for public and domestic drinking-water supply in California at times (California Department of Water Resources, 2016). To assess the quality of ambient groundwater in aquifers used for drinking-water supply and to establish a baseline groundwater-quality monitoring program, the California State Water Resources Control Board (SWRCB), in collaboration with the U.S. Geological Survey (USGS) and Lawrence Livermore National Laboratory (LLNL), implemented the Groundwater Ambient Monitoring and Assessment (GAMA) Program (http://www.waterboards. ca.gov/gama/). The SWRCB initiated the GAMA Program in 2000 in response to legislative mandates (State of California, 1999, 2001a). In 2017, the program had two active projects: the GAMA Priority Basin Project (GAMA-PBP), carried out by the USGS (http://ca.water.usgs.gov/gama/), and the GeoTracker GAMA online groundwater information system, led by the SWRCB (http://geotracker.waterboards.ca.gov/ gama/). The SWRCB's GAMA Domestic Well Project sampled private domestic wells on a voluntary, first-comefirst-served basis in six counties between 2002 and 2011. The GAMA Priority Basin Project was initiated in response to the Groundwater Quality Monitoring Act of 2001 to assess and monitor the quality of groundwater in California, to help identify and understand risks to groundwater resources better, and to increase the availability of information about groundwater quality to the public (State of California, 2001b). For the GAMA Priority Basin Project, the USGS, in collaboration with the SWRCB, developed a monitoring plan to assess groundwater basins through statistically reliable sampling approaches (Belitz and others, 2003; California State Water Resources Control Board, 2003).
From 2004 through 2012, the GAMA Priority Basin Project assessed water quality for groundwater resources used for public drinking water. The 35 study units sampled in this first phase covered over 95 percent of the groundwater water resources used for public supply statewide (Belitz and others, 2015). Groundwater basins and areas outside of basins were prioritized for sampling primarily on the basis of the distribution of wells listed in the State of California's database of public-supply wells. The California Department of Public Health Drinking Water Program, which regulated water quality in public-supply wells, was transferred to the SWRCB Division of Drinking Water (DDW) on July 1, 2014.

In 2012, the GAMA Priority Basin Project began waterquality assessments of shallow aquifers, the groundwater resources typically used for private domestic and small system drinking-water supplies. These groundwater resources typically are shallower than the groundwater resources used for public drinking-water supplies. For this phase of the GAMA-PBP, a different method of prioritization was required because there is no statewide database of domestic or smallsystem wells with which to prioritize areas for sampling. To prioritize shallow aquifers, California was divided into 938 groundwater units, corresponding to the 463 alluvial groundwater basins defined by the California Department of Water Resources (CDWR) and 453 areas outside of basins (referred to as "highlands areas"; Johnson and Belitz, 2014). The distribution of households relying on domestic wells was estimated from U.S. Census data (U.S. Census Bureau, 1990) and water-use and well-location information compiled from well-completion reports (WCRs) submitted to the CDWR (Johnson and Belitz, 2014). The groundwater units were prioritized for sampling on the basis of the number and density of households relying on domestic wells. Groundwater units were grouped into study units designed to facilitate comparison of groundwater quality between the shallow aquifer systems assessed in this second phase of the GAMAPBP and the deeper aquifer systems assessed in the first phase. The North San Francisco Bay Shallow Aquifer study unit (NSF-SA) was the first study unit assessed in the second phase of the GAMA-PBP.

The NSF-SA is in the northern Coast Ranges hydrogeologic province described by Belitz and others (2003; fig. 1). The NSF-SA includes nearly all of the area included in the GAMA Priority Basin Project assessment of groundwater resources used for public drinking water in the north San Francisco Bay as defined by Kulongoski and others, 2010, as well as additional highlands areas around the groundwater basins (fig. 2). 


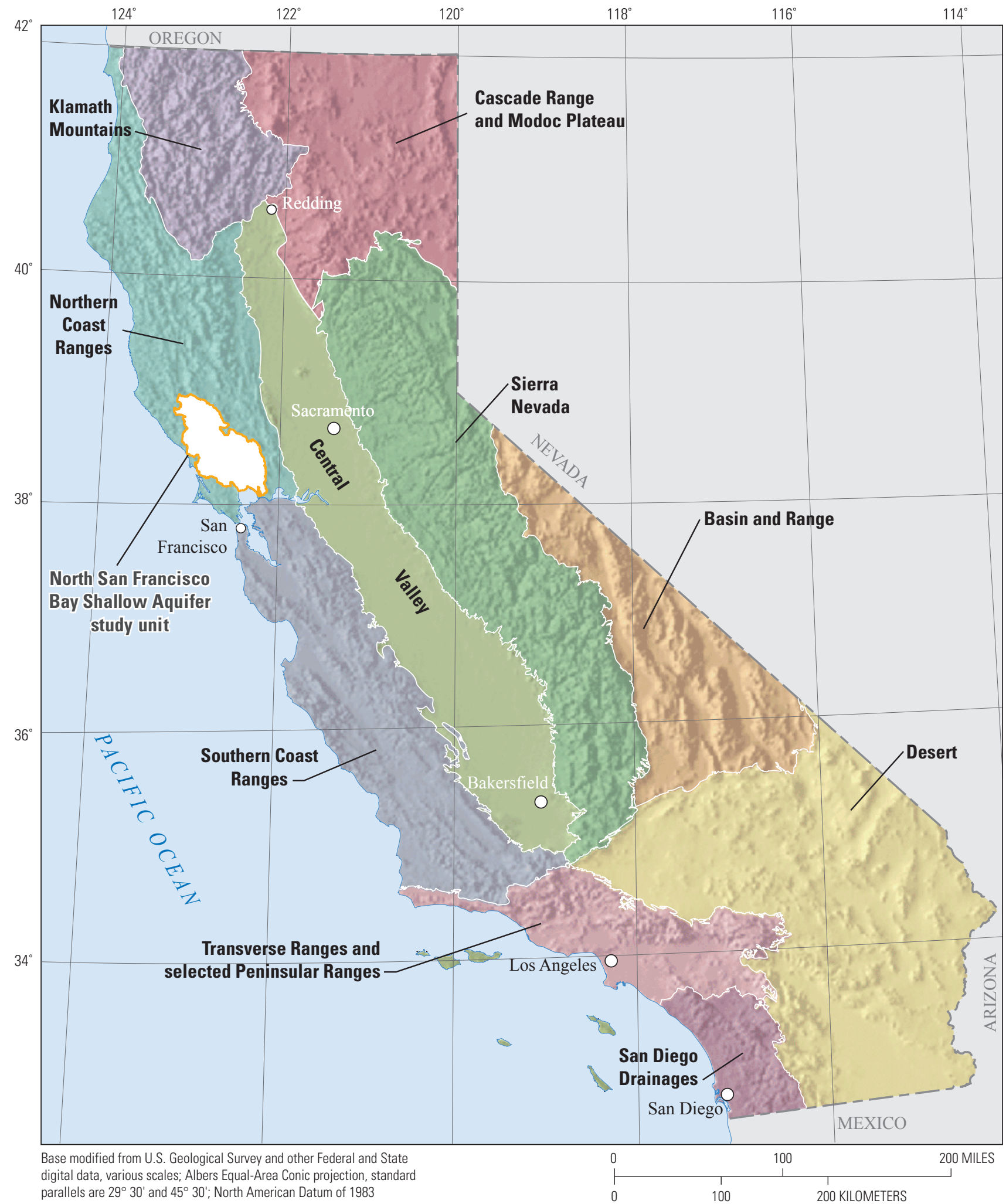

Figure 1. Hydrogeologic provinces of California and the location of the North San Francisco Bay Shallow Aquifer study unit (NSF-SA), 2012, California Groundwater Ambient Monitoring and Assessment (GAMA) Program Priority Basin Project (modified from Belitz and others, 2003). 


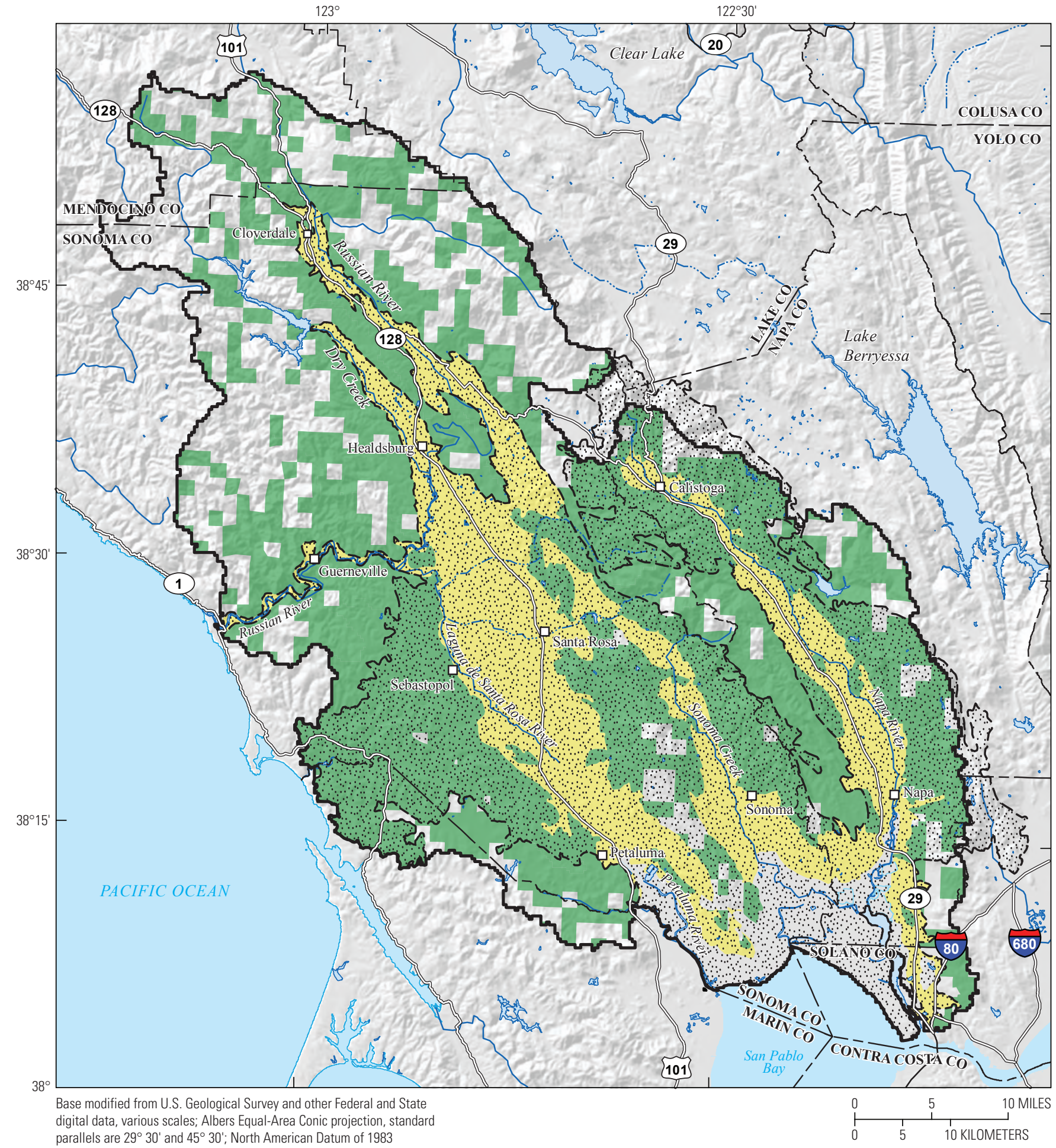

EXPLANATION

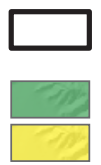

North San Francisco Bay Shallow Aquifer study unit boundary

Highlands study area

Valleys and Plains study area
North San Francisco Bay Public-Supply

Aquifer study unit boundary (Kulongoski and others, 2006)

Figure 2. Location and boundaries of the North San Francisco Bay Shallow Aquifer study unit (NSF-SA), the Public-Supply Aquifer study unit (Kulongoski and others, 2006), and the Highlands and Valleys and Plains study areas. 
The GAMA Priority Basin Project was designed to assess the status of the quality of the groundwater resources, identify natural and human factors likely affecting groundwater quality, and monitor changes in groundwater quality. These three objectives were modeled after those of the USGS National Water-Quality Assessment (NAWQA) Project (Hirsch and others, 1988). The sample collection protocols used in this study are designed to obtain representative samples of groundwater. The quality of groundwater can differ from the quality of drinking water because water chemistry can change as a result of contact with plumbing systems or the atmosphere or because of treatment, disinfection, or blending with water from other sources. The assessments in this report apply to the depth zone in the aquifer system containing groundwater resources used for domestic drinking water. In many groundwater basins, domestic and smallsystem wells typically are shallower than public-supply wells; thus, the shallow aquifer system typically corresponds to the depth zone tapped by domestic and small-system wells (for example, Burow and others, 2008; Burton and others, 2012). This separation of source water for domestic and public supply can be less distinct in some groundwater basins and in areas outside of groundwater basins, however.

This USGS scientific investigations report (SIR) is similar to other USGS SIRs written for the GAMA-PBP study units sampled to date and is the second in a series of reports presenting the water-quality data collected in the NSF-SA. Reports addressing the status, understanding, and trends of the water-quality assessments done by the GAMA Priority Basin Project are available from the USGS (http://ca.water.usgs.gov/ gama/includes/GAMA_publications.html) and the SWRCB (http://www.swrcb.ca.gov/gama/).

The purposes of this report are to provide the following: a description of the hydrogeologic setting of the NSF-SA, an assessment of the groundwater quality in the shallow aquifer system of the NSF-SA in 2012, a general identification of natural and anthropogenic factors that could be affecting groundwater quality, and a comparison between the quality of groundwater in the shallow aquifer system and the quality of groundwater resources used for public drinking water. Temporal trends in groundwater quality in the shallow and public-supply aquifer systems are not discussed in this report.

Features of the hydrogeologic setting are described for the two study areas; features of specific alluvial basins and delineated hard-rock aquifers are not discussed. Geology, landuse patterns, and hydrology of the study unit are summarized. Characteristics of groundwater resources used for domestic drinking water, including overlying land-use characteristics, depth and hydrologic conditions, geologic characteristics, and groundwater age and geochemical conditions, are described by using ancillary data compiled for the groundwater sites sampled by USGS for GAMA (USGS-GAMA) in the NSF-SA.

The status assessment was designed to provide a statistically representative characterization of groundwater resources used for domestic drinking water at the study-area scale for the time period of the assessment (Belitz and others, 2003, 2010, 2015). This report describes methods used in designing the sampling network for the status assessment and estimating aquifer-scale proportions for constituents (Belitz and others, 2010). Aquifer-scale proportion is defined as the areal proportion of the groundwater resource having groundwater of defined quality (Belitz and others, 2010). Water-quality data from 70 wells sampled by USGS-GAMA for the NSF-SA (Bennett and Fram, 2014) were used for the status assessment. Aquifer-scale proportions for constituents and classes of constituents were computed for the NSF-SA as a whole and separately for the two study areas in the study unit (the Valleys and Plains and the Highlands) by using a stratified-random sampling design (the USGS grid method) based on a 70-cell grid covering the study unit (Belitz and others, 2010, 2015).

To provide context, the water-quality data discussed in this report were compared to California and Federal regulatory and non-regulatory benchmarks for treated drinking water delivered by public water systems. Groundwater quality is defined in terms of relative concentrations (RCs), which are calculated by dividing the concentration of a constituent in groundwater by the concentration of the benchmark for that constituent. The assessments in this report characterize the quality of untreated groundwater resources in the shallow aquifer system of the study unit. The State of California does not regulate the quality of drinking water provided by domestic wells.

The evaluation of natural and human factors that could be affecting groundwater quality in the study unit is based primarily on relations between groundwater quality and potential explanatory factors. These relations are examined with statistical tests and graphical analyses and are discussed in the context of the hydrogeologic setting of the study unit. Data for the following potential explanatory factors were evaluated: aquifer lithology, land use, hydrologic conditions, depth, groundwater age, geochemical conditions, underground storage tank density, and septic tank density. Connections between potential explanatory factors and water quality are evaluated using statistical tests for correlations and by analysis of graphical relations. 
Comparisons between groundwater resources used for domestic drinking water and those used for public drinking water supply were made by comparing results from the NSF-SA (domestic drinking-water sources) samples to results obtained by the GAMA-PBP sampling of the North San Francisco Bay Public-Supply Aquifer study unit (NSF-PA; public drinking-water sources) in 2004 (Kulongoski and others, 2006, 2010). The purpose of the comparison is to identify differences in the quality of groundwater between the study units. Direct comparisons between the two study units could be made after evaluating and compensating for subtle differences in the designs of each study unit, discussed in the "Comparison of Shallow and Public-Supply Aquifer Systems" section. Differences in numerous study-unit characteristics, for example, well construction and the results of water-quality analyses in each study unit, were then identified and discussed at study-unit and study-area scales.

\section{Hydrogeologic Setting}

The NSF-SA covers an area of approximately 4,790 square kilometers $\left(\mathrm{km}^{2}\right)$, in parts of Napa, Sonoma, Mendocino, Marin, and Solano Counties in northern California (fig. 2). The study unit was divided into two study areas, the Valleys and Plains study area and the Highlands study area.

\section{Valleys and Plains Study Area}

The NSF-SA Valleys and Plains study area covers nearly $1,295 \mathrm{~km}^{2}$ and includes five CDWR-defined groundwater basins, some of which have multiple subbasins: NapaSonoma, Santa Rosa, Kenwood, Petaluma, and Alexander Valleys (California Department of Water Resources, 2003, 2004a-e, 2014a-e; Bennett and Fram, 2014). The study area covers a slightly smaller area than the NSF-PA Valleys and Plains study area of Kulongoski and others (2006, 2010). The groundwater basins are part of a series of northwest-southeast trending structural depressions in the southern part of the northern Coast Ranges province (Cardwell, 1958; Bailey and others, 1964; Fox, 1983; Farrar and others, 2006; Metzger and others, 2006). These basins consist of a relatively thin cover of Quaternary alluvium overlying a thick section of Neogene volcanics and sedimentary rocks, Cretaceous sedimentary rocks, Franciscan Complex sedimentary and metamorphic rocks of late-Jurassic to Miocene age, and Jurassic serpentinite (Bailey and others, 1964; Fox, 1983). The main water-bearing units in the basins are the alluvial sediments that range in age from Tertiary to Quaternary and are underlain and interbedded with Tertiary volcanic deposits (California Department of Water Resources, 2003, 2004a-e, 2014a-e). Notable groundwater units in the Valleys and Plains study area include Quaternary alluvial deposits, the Glen Ellen and Merced
Formations of Pliocene-Pleistocene age, and the Sonoma Volcanics of Miocene-Pliocene age.

Groundwater in the alluvium generally is unconfined and moves under a natural hydraulic gradient that conforms in a general way to the surface topography (Faye, 1973; Farrar and others, 2006; Metzger and others, 2006). Groundwater is recharged to the alluvial aquifers by stream-channel infiltration beneath the major rivers and their tributaries and by direct infiltration of precipitation on alluvial fans, with only minor recharge resulting from irrigation or other sources (Farrar and others, 2006; Metzger and others, 2006).

\section{Highlands Study Area}

The Highlands study area covers about 2,435 km²; topography ranges from rolling hills and rounded hilltops to mountainous, with mountain elevations reaching more than $1,220 \mathrm{~m}$. The study area is composed of a wide variety of geologic units with Tertiary volcanic rocks (primarily the Sonoma Volcanics) and Cretaceous marine rocks (primarily the Franciscan Complex) predominating (Weaver, 1949; Cardwell, 1958; Kunkel and Upson, 1960). Important waterbearing units in these rocks are often those with the highest porosities and transmissivities, which for the volcanic rocks are the tuffs (consolidated volcanic ash) and breccias (angular rock fragments) and for marine rocks are the conglomerates and sandstones (Farrar and others, 2006).

The Highlands study area includes the highlands area groundwater units (Johnson and Belitz, 2014) associated with the groundwater basins that define the Valleys and Plains study area. The Wilson Grove Formation Highlands also is included in the Highlands study area, although it is defined as a groundwater basin by CDWR (California Department of Water Resources, 2014f). The Wilson Grove Formation Highlands are characterized by gently rolling hills, broad valleys, and rounded hilltops between the Santa Rosa Valley and the Pacific Ocean. The water-bearing units of the Wilson Grove Formation Highlands are primarily composed of marine deposits that contain fine-grained, fossiliferous sandstones with lenses of conglomerate and sandy shale underlain by the Franciscan Complex (Fox, 1983).

\section{Methods}

This section describes the methods used for the status assessment and understanding assessment of water quality in the NSF-SA. Methods used for compiling data for the potential explanatory factors are described in appendix 1 . Methods used to collect and analyze groundwater samples are described and results for the quality-control data are evaluated by Bennett and Fram (2014). 


\section{Status Assessment}

The status assessment was designed to provide a quantitative summary of groundwater quality in the shallow aquifer system of the NSF-SA. This section describes the methods used for (1) defining groundwater quality, (2) assembling the data used for the assessment, (3) selecting constituents for evaluation, and (4) calculating aquifer-scale proportions.

\section{Groundwater Quality Defined as Relative Concentrations}

In this study, groundwater-quality data are presented as relative concentrations ( $\mathrm{RCs}$ ), which are defined as the ratio of a constituent's concentration measured in a groundwater sample to the concentration of a constituent's regulatory or non-regulatory benchmark used to evaluate drinking-water quality. The use of RC is similar to the approaches employed by other studies to place the concentrations of constituents in groundwater in a toxicological context (for example, U.S. Environmental Protection Agency, 1986; Toccalino and others, 2004; Toccalino and Norman, 2006; Rowe and others, 2007).

An $\mathrm{RC}$ value less than 1.0 indicates that the sample concentration was less than the benchmark concentration, and an $\mathrm{RC}$ value greater than 1.0 indicates that the sample concentration was greater than the benchmark concentration. The use of RCs permits comparison on a single scale for constituents that can be present at a wide range of concentrations. The RCs can only be computed for constituents with water-quality benchmarks; therefore, constituents without water-quality benchmarks were not included in the status assessment.

Regulatory and non-regulatory benchmarks apply to treated water that is served to the consumer by public water supply systems, not to untreated groundwater. To provide some context for the results, however, concentrations of constituents measured in the untreated groundwater were compared to benchmarks established by the U.S. Environmental Protection Agency (EPA), California State Water Resources Control Board Division of Drinking Water (SWRCB-DDW), and USGS. The benchmarks used for each constituent were selected in the following order of priority:

1. Regulatory, health-based levels established by the SWRCB-DDW and the EPA: SWRCB-DDW and EPA maximum contaminant levels (MCL-CA and MCL-US, respectively), EPA action levels (AL-US), and EPA treatment technique levels (TT-US; California State Water Resources Control Board, 2015a; U.S. Environmental Protection Agency, 2016).
2. Non-regulatory, health-based levels established by USGS, EPA, and SWRCB-DDW: USGS health-based screening levels (HBSL), EPA lifetime health advisory levels (HAL-US), EPA risk-specific doses for a 1:100,000 risk level (RSD5-US), and SWRCB-DDW notification levels (NL-CA; U.S Environmental Protection Agency, 2012; Toccalino and others, 2014; California State Water Resources Control Board, 2015a).

3. Non-regulatory, aesthetic-based levels established by SWRCB-DDW: secondary maximum contaminant levels (SMCL-CA; California State Water Resources Control Board, 2015a). The salinity indicators chloride, sulfate, and total dissolved solids (TDS) have recommended and upper SMCL-CA levels, and the values for the upper levels were used as water-quality benchmarks in this report.

For constituents with multiple types of benchmarks, this hierarchy might not result in selection of the benchmark with the lowest concentration. Additional information on the types of benchmarks and listings of the benchmarks for all constituents analyzed are provided by Bennett and Fram (2014).

Toccalino and others (2004), Toccalino and Norman (2006), and Rowe and others (2007) used the ratio of measured sample concentration to the benchmark concentration, either MCL-US or HBSL, and defined this ratio as the benchmark quotient (BQ). The term RC is used in this report rather than $\mathrm{BQ}$ because their respective values are not the same for the 20 constituents that have MCL-CA values that differ from their Federal counterpart MCL-US values. Disagreement also applies to the 11 constituents that have neither MCL-US nor HBSL values (thus, no associated BQ).

For ease of discussion, RCs of constituents were classified into low, moderate, and high categories. The $\mathrm{RC}$ values greater than 1.0 were defined as "high" for all constituents. For inorganic constituents (trace elements, nutrients, radioactive constituents, and other inorganic constituents having SMCL benchmarks), RC values greater than 0.5 and less than or equal to 1.0 were defined as "moderate," and $\mathrm{RC}$ values less than or equal to 0.5 were defined as "low." For organic and special-interest constituents, RC values greater than 0.1 and less than or equal to 1.0 were defined as "moderate," and RC values less than or equal to 0.1 were defined as "low." Although more complex classifications could be devised on the basis of the properties and sources of individual constituents, use of a single moderate/low threshold value for each of the two major groups of constituents provided a consistent objective criterion for distinguishing constituents present at moderate, rather than low, concentrations. 
The boundary between low and moderate RC is not intended as a demarcation of the presence of contamination from anthropogenic sources. For example, unlike the other classes of inorganic constituents, concentrations of nutrients in groundwater commonly can be strongly affected by contamination from anthropogenic sources. Concentrations of nitrate plus nitrite, referred to simply as nitrate, in groundwater greater than 1 milligram per liter $(\mathrm{mg} / \mathrm{L})$ generally are considered to indicate contamination from anthropogenic sources (Nolan and others, 2002; Dubrovsky and others, 2010). Setting the boundary between low and moderate RCs at 0.5 for nitrate (which corresponds to $5 \mathrm{mg} / \mathrm{L}$ for nitrate), therefore, results in some groundwater samples with contamination from anthropogenic sources to be categorized as a low RC for nitrate. For this study, nitrate and the other nutrient constituents were categorized as inorganic constituents, and the boundary between low and moderate RCs was set at 0.5 . Similarly, groundwater containing anthropogenic organic constituents with RCs less than 0.1 was classified as having a low RC for organic constituents, even though contamination from anthropogenic sources was present.

\section{Dataset Used for Status Assessment}

Groundwater-quality data used for the status assessment came from sites sampled by the USGS for the GAMA-PBP (fig. 3). Detailed descriptions of the methods used to identify sites for sampling are given in Bennett and Fram (2014). Briefly, the NSF-SA was divided into two study areas, the Highlands and the Valleys and Plains. Each study area was divided into equal-area grid cells (Scott, 1990) - 40 cells of $60 \mathrm{~km}^{2}$ each in the Highlands study area and 30 cells of $30 \mathrm{~km}^{2}$ each in the Valleys and Plains study area. In each cell, one groundwater site (most often a well, but springs were also considered) was randomly selected to represent the groundwater resource used for domestic supply in the cell. Sites were selected from lists of domestic-supply sites in each grid cell; lists were compiled using drillers' log information obtained from CDWR. The target lists of domestic-supply sites were then taken into the field where door-to-door canvassing was done, beginning with the site nearest to a randomly selected location in the grid cell to ensure random selection of sites. The USGS sampled one site in each of the 70 grid cells. Of the sites sampled, 4 were springs used for domestic drinking water, and the other 66 sites were domestic wells. The USGS grid sites were named with an alphanumeric GAMA identification consisting of the prefix "S-NSF-H" or "S-NSF-VP" (indicating Highlands or Valleys and Plains study areas, respectively) and a number indicating the order of sample collection. One extra site was sampled by USGS (S-NSF-HU30); two sites were sampled in the same cell (S-NSF-HU30 and S-NSF-H30). Site S-NSF-HU30 was selected and sampled initially, but this well was much shallower than the majority of the domestic wells in the cell and therefore was not considered representative of the targeted groundwater resource. As a result, S-NSF-HU30 was excluded from the status assessment, and the replacement site was named S-NSF-H30.

Samples collected from all sites were analyzed for 205 constituents (table 1). Water-quality data collected by USGS-GAMA are tabulated in Bennett and Fram (2014) and also are available from the SWRCB's database, GeoTracker GAMA (http://www.waterboards.ca.gov/gama/geotracker gama.shtml), and the USGS's publicly accessible database, NWISWeb (http://waterdata.usgs.gov/ca/nwis/).

\section{Selection of Constituents for Discussion}

Aquifer-scale proportions were calculated and are presented for the 16 individual constituents that were present at high or moderate RCs in samples from the 70 USGS grid sites (table 2). Aquifer-scale proportion results also are presented for chloroform because it had a detection frequency of greater than 10 percent in samples from the USGS grid sites (table 2).

An additional 39 inorganic and 24 organic constituents were detected but either have no drinking-water quality benchmarks or were only detected at low RCs (table 3). Aquifer-scale proportions are not presented for constituents only detected at low RCs because the proportion of the groundwater resource having low RCs for those constituents was 100 percent. Of the 205 constituents analyzed in samples collected for the NSF-SA, 119 were not detected in any of the samples (Bennett and Fram, 2014).

\section{Calculation of Aquifer-Scale Proportions}

A grid-based statistical approach (Belitz and others, 2010) was used to calculate the areal proportions of the shallow aquifer system in the NSF-SA with high, moderate, and low RCs of constituents. For ease of discussion, these proportions are referred to as "high RC," "moderate RC," and "low RC" aquifer-scale proportions. Aquifer-scale proportions were calculated for each study area and for the study unit as a whole. Calculations of aquifer-scale proportions were made for individual constituents and for classes of constituents. The classes consisted of groups of related individual constituents. Aquifer-scale proportions for constituent classes were calculated by using the maximum RC for any constituent in the class to represent the class. For example, a site having a high RC for arsenic, moderate RC for fluoride, and low RCs for molybdenum, boron, selenium, and other trace elements would be counted as having a high RC for the class of trace elements with health-based benchmarks. 


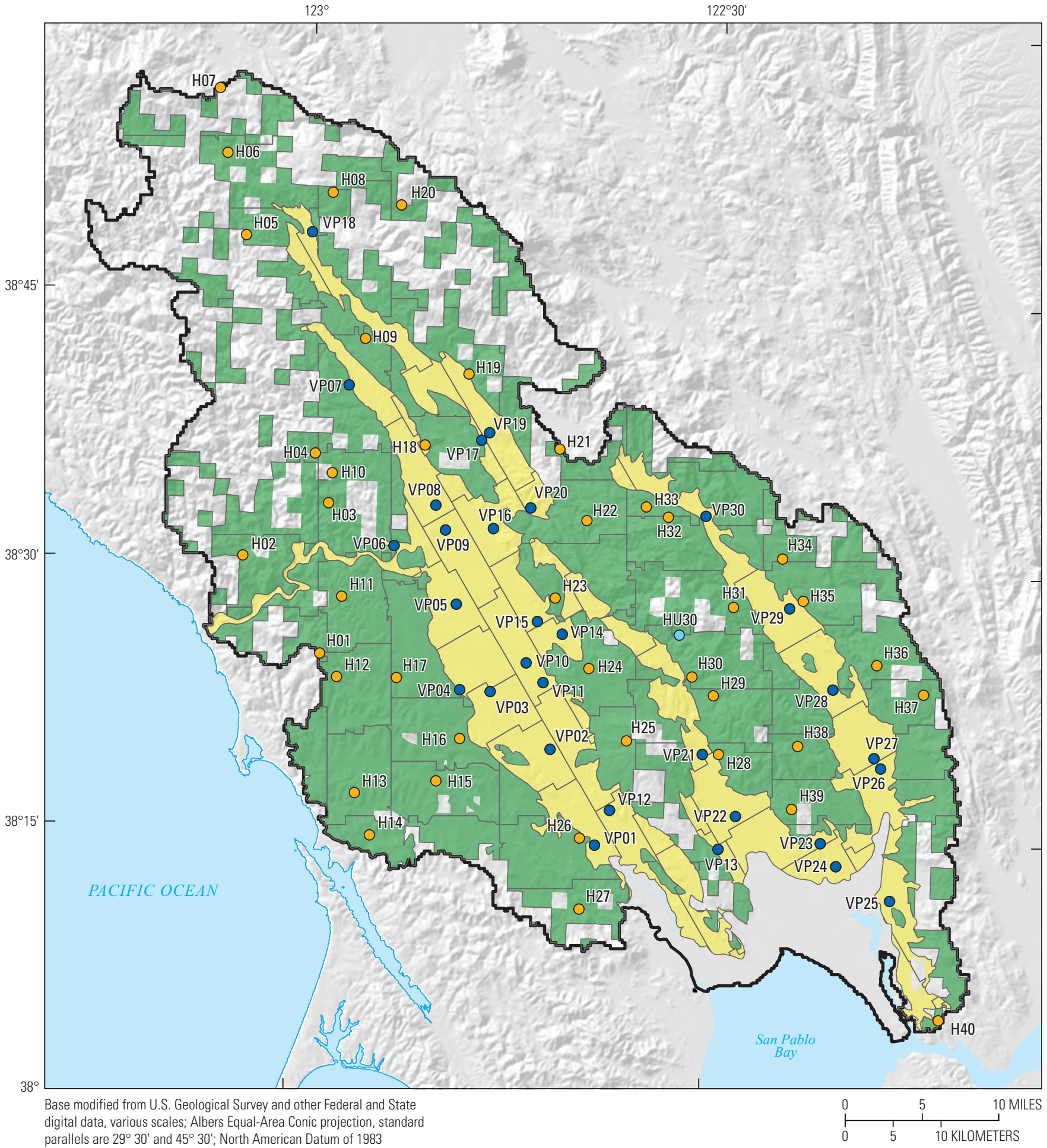

EXPLANATION

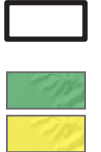

North San Francisco Bay Shallow Aquifer study unit boundary

Highlands study area

Valleys and Plains study area
Grid cell boundary

Highlands study area extra site

Highlands study area grid site

Valleys and Plains study area grid site

Figure 3. Locations of grid cells, groundwater grid sites, and the extra site sampled for the North San Francisco Bay Shallow Aquifer study unit (NSF-SA), 2012, California Groundwater Ambient Monitoring and Assessment (GAMA) Program Priority Basin Project. 
Aquifer-scale proportions were calculated for each of the study areas separately because cell sizes differed between the study areas. High-RC aquifer-scale proportion was calculated as the fraction of the USGS grid sites in the study area having high RCs for a constituent (equation 1). The moderate-RC aquifer-scale proportion was calculated similarly. Confidence intervals for high-RC aquifer-scale proportions were computed by using the Jeffreys interval for the binomial distribution (Brown and others, 2001; Belitz and others, 2010).

$$
P_{S A}^{h i g h}=\frac{N_{S A}^{h i g h}}{N_{S A}}
$$

where

$$
P_{S A}^{h i g h}=\frac{N_{S A}^{h i g h}}{N_{S A}} \text { is the high-RC aquifer-scale proportion for the }
$$$$
N_{S A}^{h i g h} \quad \text { is the number of cells in the study area }
$$
represented by a site having a high $\mathrm{RC}$ for the constituent, and

$N_{S A} \quad$ is the number of cells in the study area having a site with data for the constituent (the value of this parameter is 30 for the Valleys and Plains study area and 40 for the Highlands study area, because all USGS grid sites had data for all constituents evaluated using equation 1 ).

High-RC aquifer-scale proportions for the study unit as a whole were calculated as an area-weighted combination of the aquifer-scale proportions for the two study areas (equation 2). Moderate-RC aquifer-scale proportions for the study unit were calculated similarly.

$$
P_{S U}^{h i g h}=\Sigma F_{S A} P_{S A}^{h i g h}
$$

where

$$
\begin{gathered}
P_{S U}^{\text {high }} \begin{array}{c}
\text { is the area-weighted high-RC aquifer-scale } \\
\text { proportion for the study unit NSF-SA, }
\end{array} \\
P_{S A}^{\text {high }} \\
\begin{array}{c}
\text { is the high-RC aquifer-scale proportion for } \\
\text { each study area } S A,
\end{array} \\
F_{S A} \quad \begin{array}{c}
\text { is the fraction of the study-unit gridded area } \\
\text { occupied by each study area } S A \text {, and }
\end{array} \\
\sum \quad \text { is summation of the two study areas. }
\end{gathered}
$$

Study-unit detection frequencies for organic constituents also were calculated as area-weighted detection frequencies. The detection frequency in each study area was calculated by using equation 1 with $N_{S A}^{\text {high }}$ replaced by the number of samples with detections, and then the detection frequency for the study unit as a whole was calculated by using equation 2 after making the corresponding replacement. Because of the area weighting, the study-unit detection frequencies for organic constituents in this report can differ from the unweighted detection frequencies reported by Bennett and Fram (2014).

\section{Understanding Assessment}

For the understanding assessment, groundwater quality was viewed in a physical and chemical context framed by the potential explanatory factors. The GAMA Priority Basin Project uses statistical tests of associations between potential explanatory factors and water-quality conditions to infer processes that could be affecting water quality in a study unit. Methods used for the understanding assessment included (1) selecting constituents for additional evaluation in the understanding assessment and (2) applying statistical tests of relations between potential explanatory factors and selected groundwater-quality constituents.

\section{Selection of Constituents}

A subset of constituents was selected for additional evaluation in the understanding assessment. This subset includes two groups: individual constituents present at high $\mathrm{RCs}$ in greater than 2 percent of the groundwater resource used for domestic supply and organic constituent classes detected at any concentration in greater than 10 percent of the resource. These criteria resulted in selection of seven individual constituents, one organic constituent class, and one special-interest constituent (table 2).

\section{Statistical Analysis}

Nonparametric statistical tests were used to test the significance of correlations among potential explanatory factors and between water-quality constituents and potential explanatory factors. Nonparametric statistics are robust techniques that are generally resistant to the effects of outliers and do not require that the data follow any particular distribution (Helsel and Hirsch, 2002). The attained significance level $(p)$, the significance level of the test statistic attained from the selected data used for hypothesis testing for this report, unless otherwise noted, was compared to a critical level $(\alpha)$ of 5 percent $(\alpha=0.05)$ to evaluate whether the relation was statistically significant ( $p$ less than $\alpha$ ).

Three different statistical tests were used because the set of potential explanatory factors included categorical and continuous variables. Groundwater age class, oxidationreduction (redox) class, and study area were treated as categorical variables. Land use, septic tank density, underground storage tank (UST) density, aridity index, elevation, well depth, depth to top of screened or open interval, $\mathrm{pH}$, and dissolved oxygen were treated as continuous variables. Concentrations of water-quality constituents were treated as continuous variables. 
Correlations between potential explanatory factors and water-quality constituents were tested for significance.

- Correlations between continuous variables were evaluated using the Spearman's rank-correlation test to calculate the rank-order correlation coefficient $(\rho$, or rho) and to determine whether the correlation was significant $(p$ less than $\alpha$ ).

- Relations between categorical variables and continuous variables were evaluated using the Kruskal-Wallis and Wilcoxon rank-sum tests. The null hypothesis for these tests is that the median values of the continuous variable do not significantly differ among or between categories, respectively.

- Relations between categorical variables were evaluated by using contingency tables. For contingency table analysis, the data are recorded as a matrix of counts. One variable is assigned to the columns and the other to the rows. The statistical test for independence compares the observed counts to the counts expected if the two variables are independent, and statistical significance is determined by comparing the test statistic $(1-\alpha)$ to the quantile of a chi-square distribution (Helsel and Hirsch, 2002). If the contingency table test detected a significant difference between the observed counts and the expected counts, then the matrix cell, or cells, contributing the most to the difference was identified by comparing the magnitudes of the components of the test statistic (Helsel and Hirsch, 2002).

\section{Comparison Between NSF-SA and NSF-PA}

The comparison between the study units focused on two different aspects: study-unit characteristics and results of groundwater-quality analyses. Differences between the NSF-SA and NSF-PA characteristics were evaluated in order to identify dissimilarities that could affect interpretations of differences between the study units with respect to the groundwater-quality results. Wilcoxon rank-sum tests were used to evaluate relationships between categorical and continuous study-unit variables; graphical comparisons of trilinear diagrams were done when evaluating the chemical composition of groundwater in each study unit, and if an appropriate statistical test or graphical comparison could not be applied, a qualitative comparison was made.

Although some differences can appear more notable than others, statistically significant differences between the study units and study areas were tested using contingency table tests ( 2 by 2 ). The significance level ( $p$ ) used when testing these differences was based on a threshold value $(\alpha)$ of 10 percent $(\alpha=0.1)$. As already noted, if the test statistic $p$ was less than $\alpha$, there was a statistically significant difference. A higher threshold value for significance was used for this part of the study to permit discussion of differences that would have been defined as not significant relative to the lower threshold value used for the rest of this study. The contingency tables were constructed to compare counts of sites with (1) high or moderate RCs against those with low RCs and (2) high RCs against low or moderate RCs. These tests were run for the inorganic constituent groups and for individual constituents.

Using the framework established in the status and understanding assessments of the NSF-PA and NSF-SA, constituents selected for additional evaluation are the focus of the comparison between the study units with respect to groundwater quality. It should be noted that individual constituent aquifer-scale proportions and proportions of constituent groups by class presented in the assessment of status and understanding for the NSF-SA discussed later in this report were recalculated for the comparison with the NSF-PA. Adjustment was necessary to prevent sites outside of the area of comparison from being included in the comparison of the two study units. Grid-based proportions and proportions of constituent groups by class presented in Kulongoski and others (2010) for the NSF-PA also were recalculated. This was done to ensure that the same water-quality benchmarks were applied to calculate RCs for both study units. Benchmark threshold levels for some constituents and the relative hierarchy among benchmarks had changed between the times that the NSF-PA and NSF-SA were respectively sampled. For example, in the NSF-SA, the manganese concentrations were compared to a USGS-defined Health Based Screening Level of 300 micrograms per liter $(\mu \mathrm{g} / \mathrm{L})$. In the NSF-PA, concentrations of manganese were compared to the California SMCL of $50 \mu \mathrm{g} / \mathrm{L}$. For a consistent comparison of RCs and frequencies of RC class membership, benchmark thresholds and the benchmark hierarchy used with the 2012 NSF-SA sampling results were used for study-unit comparisons.

Not all of the wells sampled in the NSF-PA by USGSGAMA had analyses of major and minor ions, trace elements, and nutrients. For those wells in the NSF-PA missing data for inorganic constituents, the SWRCB-DDW public-supply well database was queried. Suitable inorganic data from this database were then selected to complete the dataset. The detailed process used for selecting this additional SWRCBDDW data for inclusion in the NSF-PA is described in Kulongoski and others, 2010. Lastly, reporting levels for organic and special-interest constituents were evaluated if a constituent's reporting level changed between 2004 and 2012; constituent nondetections were re-censored at the higher of the two reporting levels. 


\section{Potential Explanatory Factors}

Features of the hydrogeologic setting are described on the scale of the entire NSF-SA; features of specific alluvial basins and delineated hard-rock aquifers are not discussed. Geology, land-use patterns, and hydrology of the study unit are summarized. Characteristics of the shallow aquifer system are described using explanatory factor data compiled for the 71 sites sampled by USGS-GAMA for the study unit. The presence of correlations among explanatory factors can confound interpretation of correlations between explanatory factors and groundwater quality, so correlations among explanatory factors are discussed in this section. The methods used for assigning values for each of the explanatory factors to the 71 sites sampled by USGS-GAMA in the NSF-SA are described in appendix 1.

For this report, the shallow aquifer system is defined by the depth intervals of wells used for domestic drinkingwater supply. The use of the term "shallow aquifer system" does not imply that there exists a discrete aquifer unit. In most groundwater basins, public-supply wells generally are screened or open at greater (deeper) depths than are domestic wells (for example, Burow and others, 2008; Burton and others, 2012).

Apparent correlations between potential explanatory factors and water-quality constituents could be spurious, resulting from correlations among potential explanatory factors; therefore, identification of statistically significant correlations between potential explanatory factors is important (tables 4,5 ). The potential explanatory factors examined in the NSF-SA are frequently correlated with one another. For instance, nearly all of the potential explanatory factors are significantly related to aquifer lithology (table 4). Sedimentary aquifer lithology is positively related with the percentage of urban and agricultural land uses and negatively related with the percentage natural land use. This relation reflects the fact that urban and agricultural land uses are preferentially on sedimentary basin deposits because low-relief landforms and gentle slopes favor such development, and the soil is typically more suitable for agriculture. This relation is further reflected in the significantly higher density of septic tanks and USTs in areas with greater percentages of urban land uses and a negative relation of UST densities with percent natural land use (table 5).

\section{Aquifer Lithology}

The geology of the NSF-SA is complex. For the purpose of examining broad relations between aquifer lithology and groundwater quality, the various geologic units of the study unit, as represented on the State geologic map (Jennings, 1977; Saucedo and others, 2000), were grouped into three general rock types (fig. 4; appendix 1):
- Metamorphic rocks: includes rocks of the Franciscan Complex and Cretaceous marine metasediments.

- Volcanic rocks: volcanic rocks including pyroclastic flows and mudflows of Mesozoic to Cenozoic age and ultramafic rocks of the northern Coast Ranges.

- Sedimentary rocks: Cenozoic Era rocks including Plio-Pleistocene marine and nonmarine deposits and Quaternary alluvium of marine and nonmarine origin.

The lithology of the Valleys and Plains study area is composed entirely of sedimentary deposits, and that of the Highlands study area is composed of metamorphic and volcanic rocks (fig. 4).

\section{Land Use}

Land use was characterized by three land-use types: natural, urban, and agricultural (appendix 1). Percentages of the three types were calculated for the study unit and study areas as a whole and for the circular area with a radius of 500 meters $(\mathrm{m})$ around each USGS grid site (Johnson and Belitz, 2009). As of 2011, overall land use in the NSF-SA was 73 percent natural, 16 percent urban, and 11 percent agricultural (figs. 5B, 6; Jin and others, 2013). Land use in the Valleys and Plains study area was 35 percent natural, 34 percent urban, and 31 percent agricultural, whereas land use in the Highlands study area was 90 percent natural, 8 percent urban, and 2 percent agricultural (fig. $5 B$ ). Nearly all of the agricultural land use was in the Valleys and Plains study area (fig. 6).

Like the overall study-unit composition, land use in the buffered areas surrounding the USGS grid sites was primarily natural. The biggest differences noted when comparing landuse percentages calculated over the entire study-unit area and land-use percentages calculated using the buffers were for the percentages of urban and natural land use. Urban land use in the areas in the buffers surrounding the grid sites ( 25 percent on average) was greater than in the overall result, and natural land use was less (59 percent on average). Around individual grid sites, land use ranged from 0 to 100 percent urban, with 23 of 70 sites surrounded by greater than 20-percent urban land use (fig. 5A; appendix table 1-1).

Septic tanks and USTs are also markers of land-use patterns. The average densities of USTs and septic tanks near a groundwater site can be indicators of potential sources of anthropogenic contaminants near the land surface. The density of USTs around grid sites ranged from 0.01 to about 33 tanks per square kilometer $\left(\operatorname{tanks} / \mathrm{km}^{2}\right)$, and the median density was 0.08 tanks $/ \mathrm{km}^{2}$ (appendix table 1-1). A description of how the Thiessen polygon method (2011) was used to calculate UST density is included in appendix 1 . The mean density of septic tanks around grid sites ranged from 0 to nearly 54 tanks $/ \mathrm{km}^{2}$, and the median density was 5.0 tanks $/ \mathrm{km}^{2}$ (appendix table 1-1). 


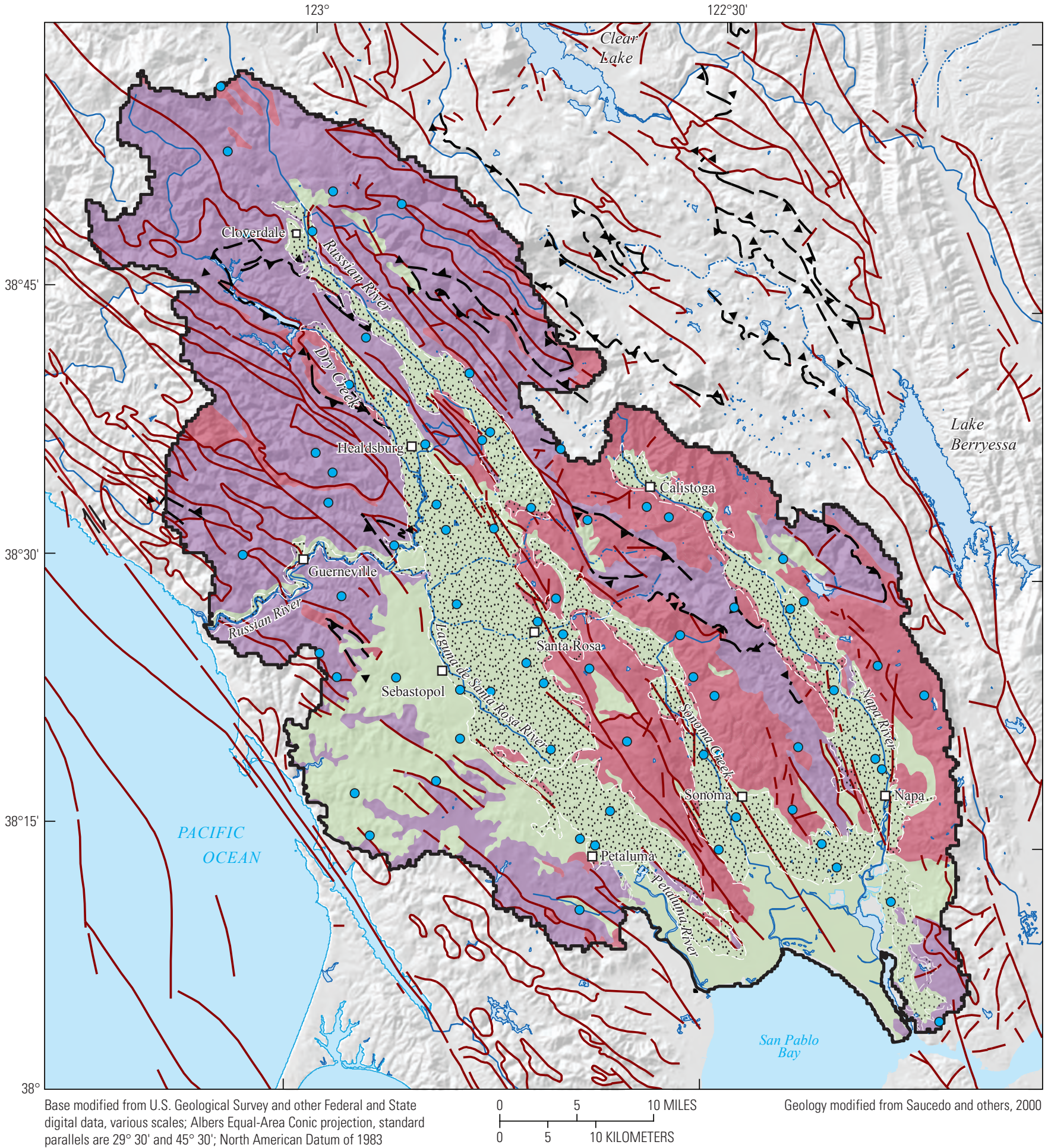

parallels are $29^{\circ} 30^{\prime}$ and $45^{\circ} 30^{\prime}$; North American Datum of 1983

\section{EXPLANATION}

North San Francisco Bay Shallow Aquifer study unit boundary

Valleys and Plains study area

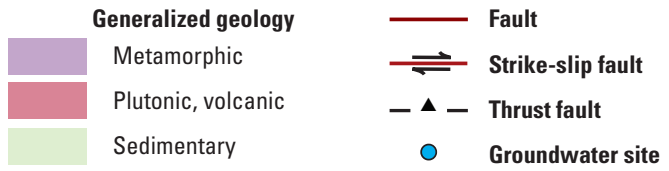

Figure 4. Surficial lithologic categories of the North San Francisco Bay Shallow Aquifer study unit (NSF-SA), California Groundwater Ambient Monitoring and Assessment (GAMA) Program Priority Basin Project (modified from Saucedo and others, 2000). 

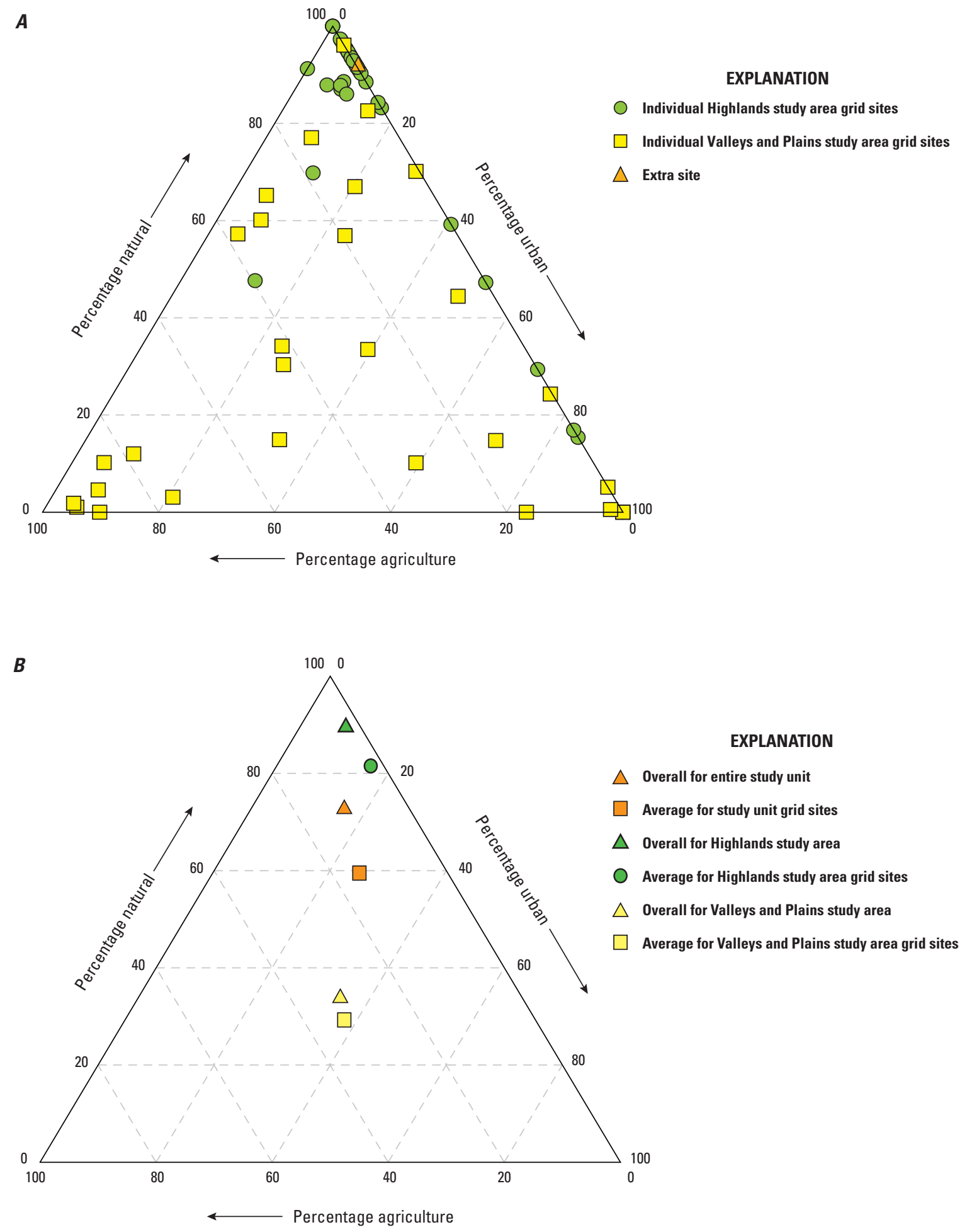

Figure 5. Land use of the North San Francisco Bay Shallow Aquifer study unit (NSF-SA) for 2011, California Groundwater Ambient Monitoring and Assessment (GAMA) Program Priority Basin Project: $A$, percentages of urban, agricultural, and natural land use surrounding individual US Geological Survey grid and extra sites and $B$, overall land-use composition of the study unit and study areas. 


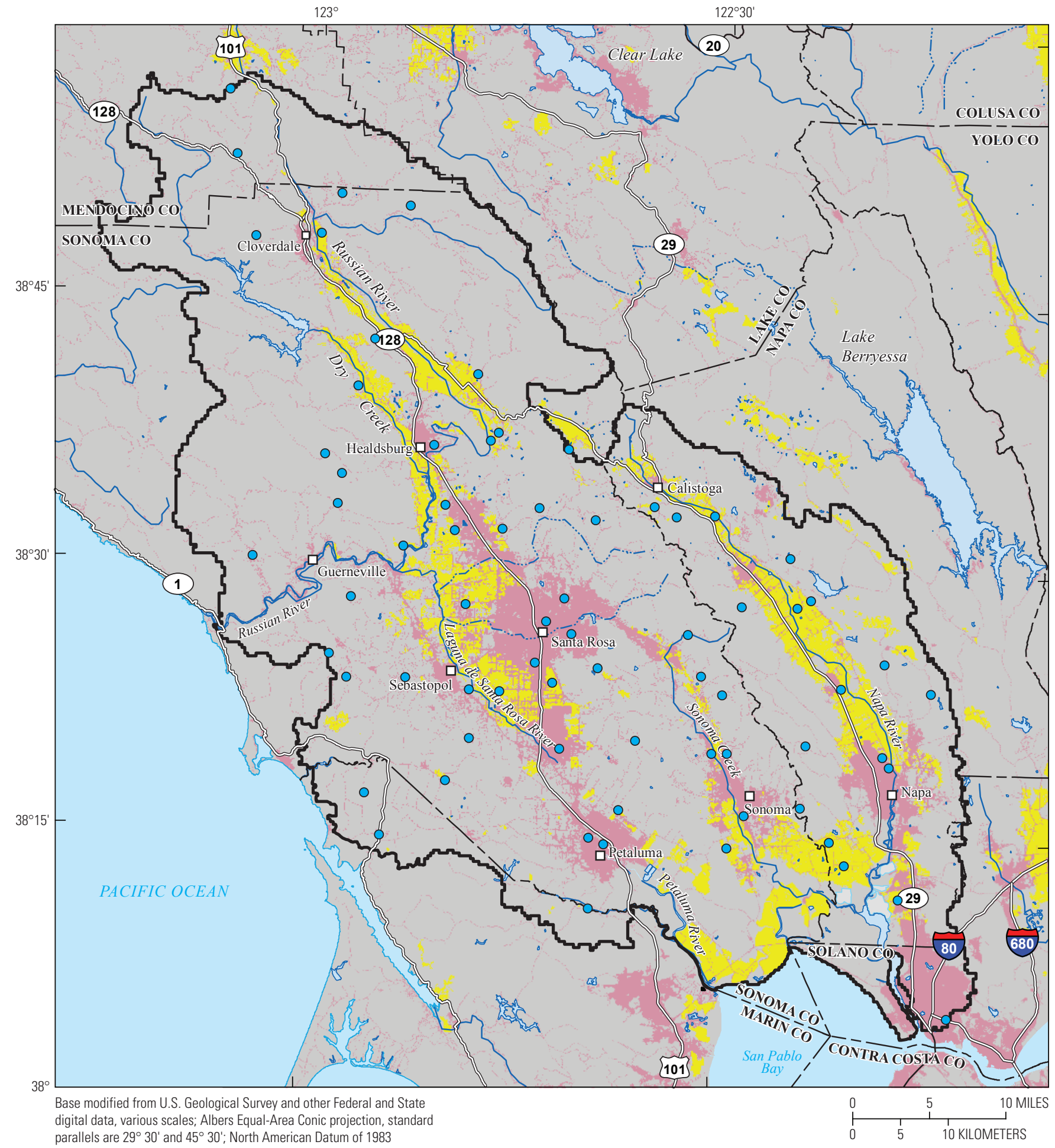

EXPLANATION

Land use, National Land Cover Database (2011)

Urban
Agriculture
Natural
North San Francisco Bay Shallow Aquifer study unit boundary

- Groundwater site

Figure 6. The 2011 land use and locations of groundwater sites in the North San Francisco Bay Shallow Aquifer study unit (NSF-SA), sampled in 2012, California Groundwater Ambient Monitoring and Assessment (GAMA) Program Priority Basin Project. 
The agricultural and urban land-use percentages were greater in the areas of sedimentary lithology than for either the metamorphic or volcanic lithologies and therefore were greater in the Valleys and Plains study area than in the Highlands study area (table 4). The percentage of natural land use was greater in the areas of metamorphic and volcanic lithologies than in areas of the sedimentary lithology and therefore was greater in the Highlands study area than in the Valleys and Plains study area (table 4). Underground storage tank densities were greater in the sedimentary lithology than in the volcanic or metamorphic lithologies; however, only UST density was greater in the Valleys and Plains study area than in the Highlands study area and was greater in areas of sedimentary rather than volcanic lithology (table 4). Septic tank density was greater in the sedimentary lithology than in the metamorphic lithology (table 4).

\section{Hydrologic Conditions}

Hydrologic conditions are represented by elevation and aridity index at each groundwater site (appendix table 1-1). Land-surface elevations in the NSF-SA range from about sea level where the NSF-SA borders the San Pablo Bay in the south to over $1,444 \mathrm{~m}$ in the northeast part of the NSF-SA (fig. 2). None of the sampled groundwater sites were at an elevation above $580 \mathrm{~m}$, however (appendix table 1-1).

The climate in the study unit is typical of mountainous areas in northern California, with warm, dry summers and cold, wet winters (U.S. Department of Commerce, National Climatic Data Center, 2012). The National Climatic Data Center station in Napa, Calif. (fig. 2), which is in the southeastern part of the study unit, reported an average annual temperature of $56^{\circ} \mathrm{F}\left(13^{\circ} \mathrm{C}\right)$ and an average annual precipitation of 20 inches. In contrast, Cloverdale, Calif. (fig. 2), which is in the northwestern end of the study unit, had an average annual temperature of $61^{\circ} \mathrm{F}\left(16^{\circ} \mathrm{C}\right)$ and average annual precipitation of 43 inches. This general decrease in precipitation from north to south and west to east is due to the rain-shadow effect of the mountain ranges in the study unit and prevailing winter weather patterns, when cyclonic storms come from the Pacific Ocean into northern California during the rainy season (Western Regional Climate Center, 2016).

The aridity index was used as an indicator of climate. Aridity index is defined as average annual precipitation divided by average annual evapotranspiration and is identical to the United Nations Educational, Scientific, and Cultural Organization Aridity Index (United Nations Educational, Scientific, and Cultural Organization, 1979; United Nations Environment Programme, 1997). The aridity index was positively correlated to elevation in the NSF-SA (table 5), meaning that conditions were wetter at higher elevations. Aridity-index values at USGS-GAMA sites ranged from 0.46 to 1.36 (appendix table 1-1). Of the 71 sites sampled in the NSF-SA, 84 percent had an aridity index in the humid or wet category (aridity index greater than 0.65 ) as defined by the United Nations Environment Programme (1997), with only two sites having aridity-index values less than 0.50 , or semiarid. Sites with metamorphic and volcanic aquifer lithologies had significantly higher aridity-index values than sites in the sedimentary aquifer lithology class (table 4); however, this is an example of correlation between two explanatory factors that was unrelated to direct causation. The metamorphic and volcanic aquifer lithologies are most often found in the Highlands study area, which, as the name implies, is at a higher elevation than the Valleys and Plains study area. As noted earlier, the positive correlation between aridity index and elevation was primarily the result of orographic effects.

\section{Depth and Groundwater Age Characteristics of the Shallow Aquifer System}

Of the 41 sites sampled by USGS-GAMA in the Highlands study area, 4 were springs. In this report, springs are not assigned values for the depths to the top and bottom of screened or open intervals and are therefore not included in tests involving depth as a continuous variable. Springs emerge at land surface, but the geometry of the fracture network in the subsurface is unknown.

Well depth information was available for 65 (64 USGS grid wells and 1 extra well) of the 67 wells sampled. When USGS grid wells from the Highlands study area and the Valleys and Plains study area, there was no significant difference between study areas for either well depth or depth to top of screened or open interval (fig. 7). Depths of USGS grid wells ranged from 6 to $230 \mathrm{~m}$ below land surface; the median well depth was $55 \mathrm{~m}$ (fig. 7; appendix table 1-2). Depth to the top of screened or open interval was available for 57 (56 USGS grid wells and 1 extra well) of those 65 wells with construction information. Depths to the top of the screened or open interval ranged from 3 to $134 \mathrm{~m}$, with a median of $21 \mathrm{~m}$. The screened or open interval length ranged from 2 to $120 \mathrm{~m}$, with a median of $34 \mathrm{~m}$.

Groundwater age refers to the length of time that the water has resided in the aquifer system, which is the amount of time elapsed since the water was last in contact with the atmosphere. Groundwater samples were assigned to groundwater age classes on the basis of the tritium and carbon-14 $\left({ }^{14} \mathrm{C}\right.$ ) activity in the samples (see "Groundwater Age" section in appendix 1). Samples from 17 sites were classified as modern water (recharged after 1952), samples from 41 sites were classified as mixed (having a substantial component of modern and pre-modern water), and samples from 13 sites were classified as pre-modern water (recharged prior to 1952; appendix table 1-3).

Classified groundwater ages typically increase with well depth and with depth to the top of the screened or open interval. Groundwater of the modern age class came from wells with significantly shallower depths than groundwater of the pre-modern age class (fig. 8; table 4). Groundwater of premodern age came from wells with significantly greater depths to the top of the screened or open interval than groundwater of modern age (fig. 8; table 4). 


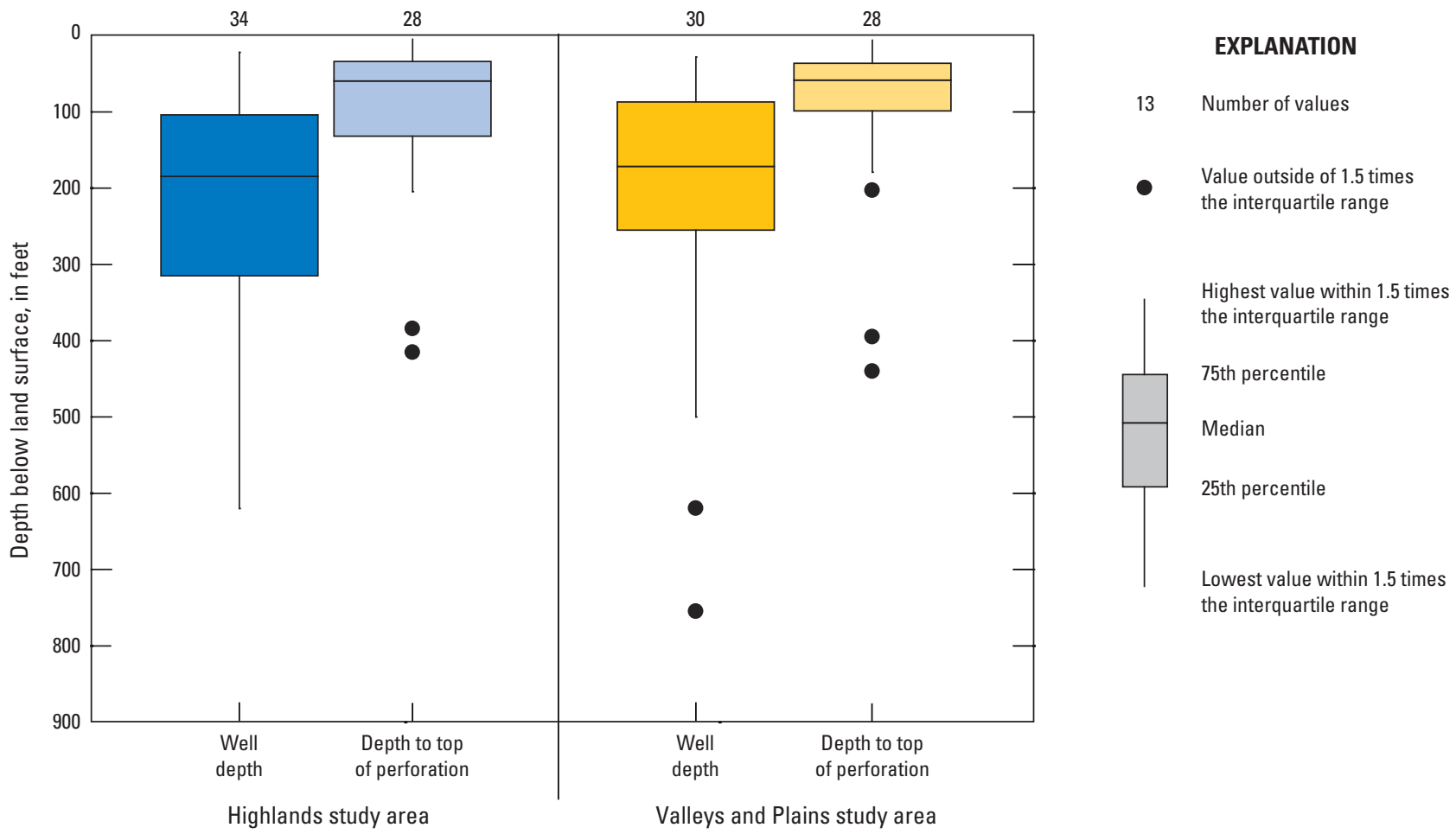

Figure 7. Well depth and depth to top of perforation for U.S. Geological Survey sampled grid wells, North San Francisco Bay Shallow Aquifer study unit (NSF-SA), 2012, California Groundwater Ambient Monitoring and Assessment (GAMA) Program Priority Basin Project.

$\boldsymbol{A}$

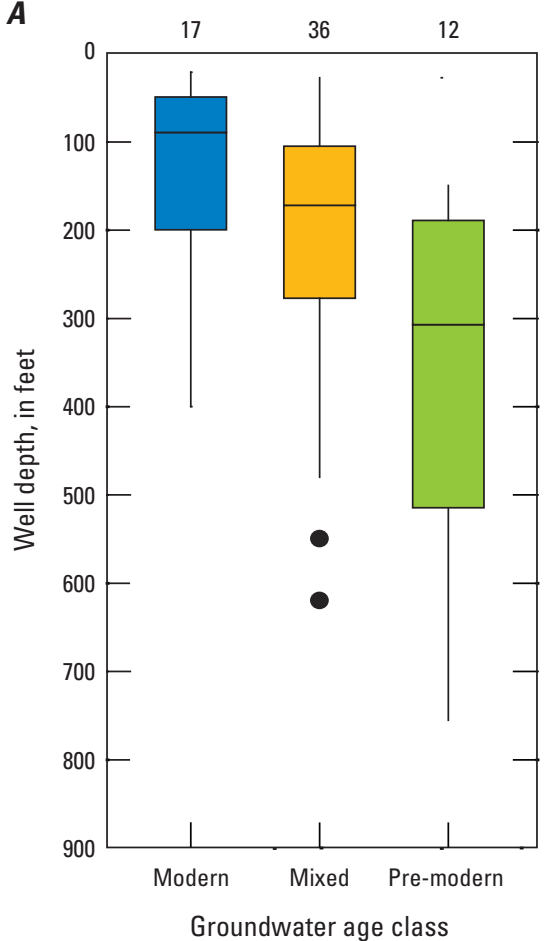

B

EXPLANATION

17 Number of values

Value outside of 1.5 times

the interquartile range

Highest value within 1.5 times

the interquartile range

75th percentile

Median

25th percentile

Lowest value within 1.5 times

the interquartile range

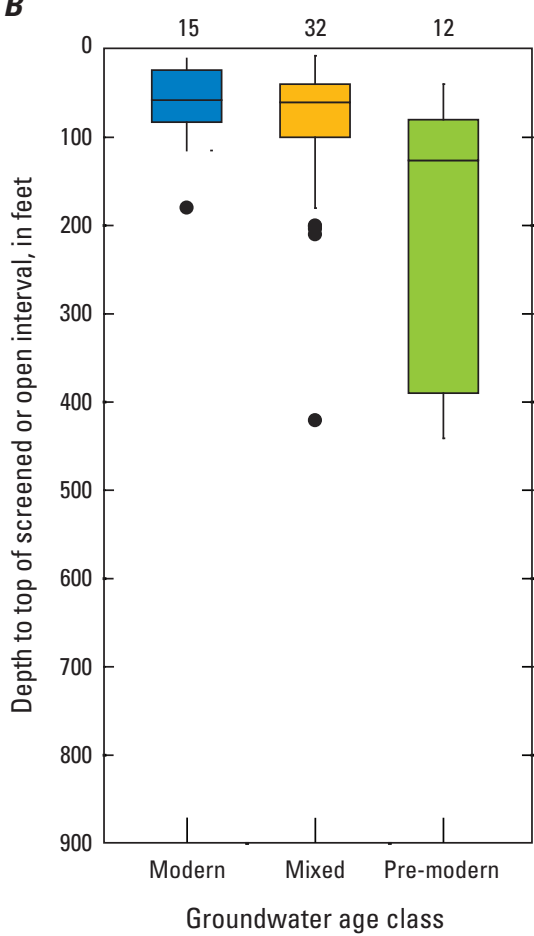

Figure 8. Summaries of groundwater classified as modern, mixed, or pre-modern in age, North San Francisco Bay Shallow Aquifer study unit (NSF-SA), 2012, California Groundwater Ambient Monitoring and Assessment (GAMA) Program Priority Basin Project, by $A$, well depth and $B$, depth to top of screened or open interval for wells. 


\section{Geochemical Conditions}

Oxidation-reduction (redox) conditions for the 71 sites sampled by USGS-GAMA were classified using the redox classification framework of McMahon and Chapelle (2008) and Jurgens and others (2009; appendix table 1-4). Groundwater conditions were often anoxic (40 of 71 sites). Samples from 26 sites had oxic conditions, and the remaining 5 sites had mixed redox conditions. Dissolved oxygen concentrations were significantly higher in samples from sites in the volcanic aquifer lithology class than in those from either the sedimentary or metamorphic aquifer lithology classes (table 4). Dissolved oxygen concentrations were also significantly higher in the Highlands study area relative to the Valleys and Plains study area, and samples classified as oxic were collected from significantly higher elevations than samples classified as anoxic (table 4). This relation corresponds with the fact that the volcanic aquifer lithology is almost entirely in the Highlands study area (fig. 3).

Among all samples, values for $\mathrm{pH}$ ranged from 6.0 to 9.4 (appendix table 1-4). At sites with sedimentary and metamorphic aquifer lithologies, samples had higher $\mathrm{pH}$ than was observed in samples from the volcanic aquifer lithology (table 4). Values for $\mathrm{pH}$ were also significantly higher in samples classified as anoxic than in samples classified as oxic (table 4).

\section{Status and Understanding of Groundwater Quality in the Shallow Aquifer System}

The discussion of the status and understanding assessment results is divided into two parts, one for inorganic and the other for organic constituents. Each part begins with a survey of the number of constituents that were detected at any concentration compared to the number of constituents analyzed and includes a graphical summary of the RCs of constituents detected in samples from the grid sites. Aquiferscale proportions are then presented for constituent classes and for the individual constituents that were present at moderate or high RCs (constituents present only at low RCs have aquiferscale proportions of 100 percent low RC). Finally, results of statistical tests for relations between water quality constituents and potential explanatory factors are presented for the individual constituents and constituent classes that met further criteria based on RCs or, for organic constituents, detection frequency.

\section{Inorganic Constituents}

Inorganic constituents generally are natural in groundwater, although their concentrations can be influenced by human activities as well as by natural factors (Hem, 1985). All 50 inorganic constituents analyzed by the USGS-GAMA were detected in the NSF-SA. Of these 50 constituents, 28 had regulatory or non-regulatory health-based benchmarks, 6 had non-regulatory aesthetic-based benchmarks, and 16 had no established benchmarks (Bennett and Fram, 2014). Most of the constituents without benchmarks are major or minor ions that are present in nearly all groundwater (table 3 ). Of the 34 inorganic constituents that had benchmarks, 12 were detected at moderate or high RCs in the grid sites: the trace elements with health-based benchmarks arsenic, barium, boron, fluoride, manganese, strontium, and vanadium; the nutrient nitrate; and the inorganic constituents with aestheticbased secondary maximum contaminant level (SMCL) benchmarks chloride, iron, sulfate, and total dissolved solids (TDS; table 2; figs. 9, 10A-D). Seven inorganic constituents were selected for further evaluation in the understanding assessment because they were present at high RCs in greater than 2 percent of the shallow aquifer system: arsenic, boron, fluoride, manganese, nitrate, iron, and TDS (table 2).

Radon-222 was the only radioactive constituent present at high or moderate RCs in the NSF-SA; it was detected at high RC in two samples and at moderate RC in two samples, all in the Highlands study area. Radon-222 was not evaluated further as part of the selected inorganic constituents, however, because the reason for its MCL-US (proposed since 1999) is related to radon-222 levels of indoor air, not health concerns associated with ingestion of drinking water containing radon222. This study is focused on constituents of concern related to drinking water.

Inorganic constituents having human-health benchmarks, as a group (nutrients and trace elements), had high RCs in 27 percent of the shallow aquifer system and moderate RCs in 21 percent (table $6 A$ ). Inorganic constituents having aestheticbased benchmarks, as a group, had high RCs in 24 percent of the shallow aquifer system and moderate RCs in 16 percent.

\section{Trace Elements}

Trace elements with health-based benchmarks, as a class, had high RCs (for one or more constituents) in 25 percent of the shallow aquifer system and moderate values in 21 percent (table 6A). The proportion of the shallow aquifer of the Valleys and Plains study area with high RCs of trace elements (47 percent) was greater than the corresponding proportion of the Highlands study area (15 percent). Arsenic and manganese were present at high RCs in samples from the Valleys and Plains study area, and boron, fluoride, and manganese were present at high RCs in samples from the Highlands study area (fig. 10). Maximum RCs of barium, strontium, and vanadium in sampled groundwater were at moderate RCs (table 7, fig. 10). 


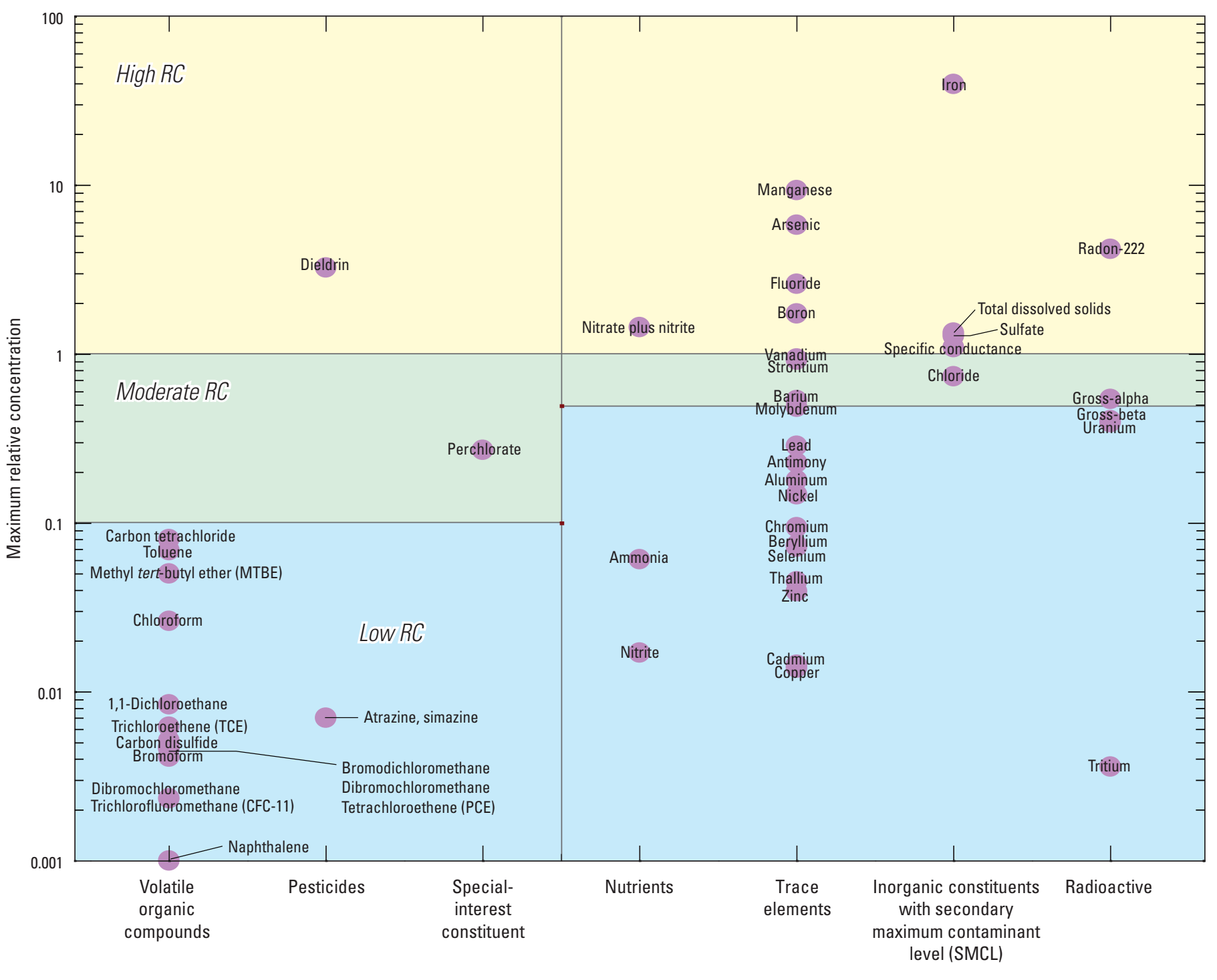

EXPLANATION

Perchlorate Center of symbol is at data value for constituent

Five volatile organic compounds, two pesticides, and one trace

element were detected at relative concentrations $(\mathrm{RC})<0.001$

Figure 9. Maximum relative concentrations for constituents detected in U.S. Geological Survey grid sites by type of constituent, North San Francisco Bay Shallow Aquifer study unit (NSF-SA), 2012, California Groundwater Ambient Monitoring and Assessment (GAMA) Program Priority Basin Project. 
$\boldsymbol{A}$
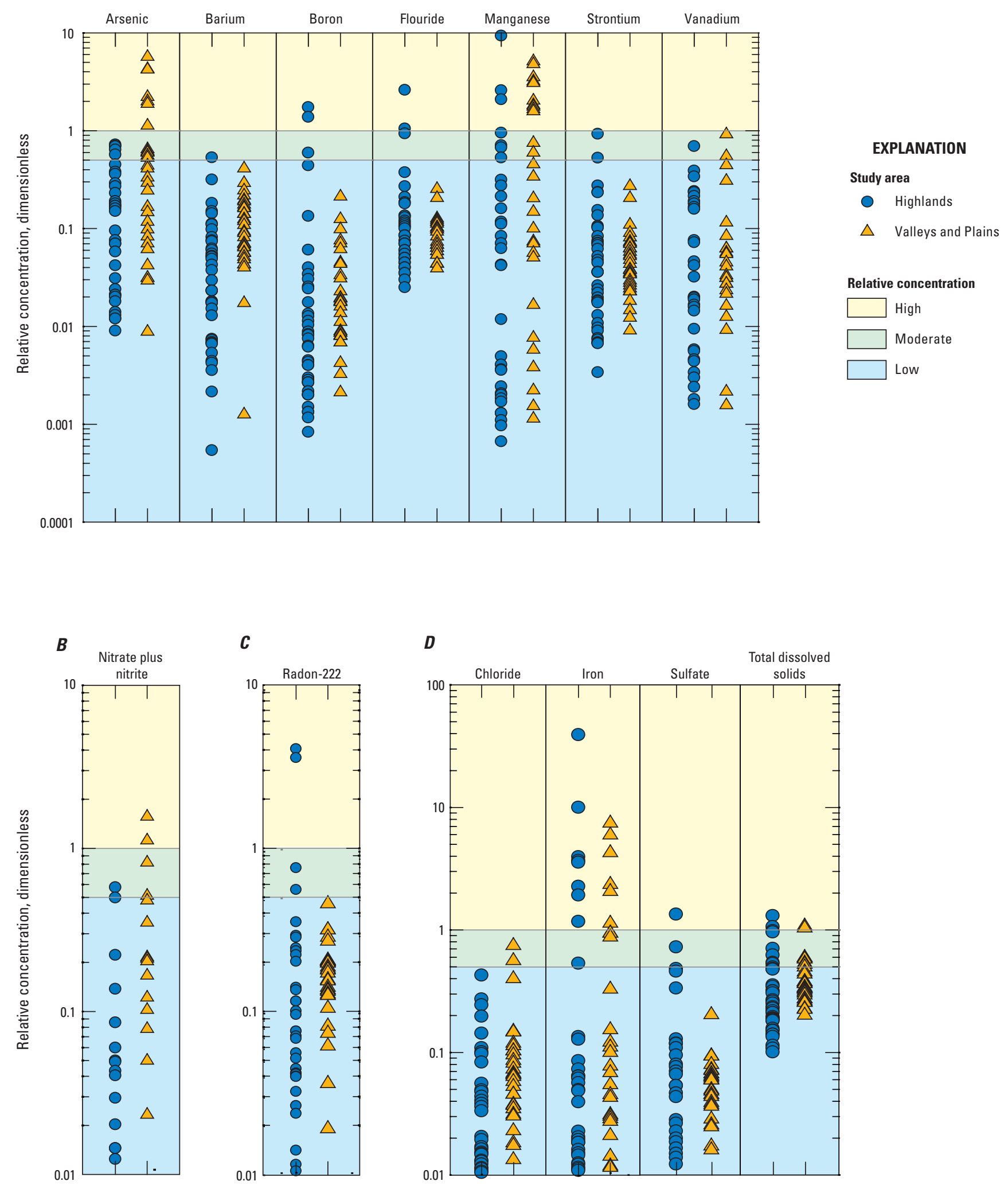

Figure 10. Relative concentrations of selected constituent classes in samples from U.S. Geological Survey grid sites, North San Francisco Bay Shallow Aquifer study unit (NSF-SA), 2012, California Groundwater Ambient Monitoring and Assessment (GAMA) Program Priority Basin Project: $A$, trace elements; $B$, nutrients; $C$, radioactive constituents; and $D$, inorganic constituents (with nonregulatory aesthetic-based benchmarks). 


\section{Arsenic}

Arsenic is a semi-metallic trace element. Natural sources of arsenic in groundwater include dissolution of arsenicbearing minerals, desorption of arsenic from mineral surfaces, and mixing with hydrothermal fluids (Welch and others, 2000; Smedley and Kinniburgh, 2002). Pyrite, the most common sulfide mineral in aquifer materials, can contain up to several percent of arsenic. Potential anthropogenic sources of arsenic can include copper ore smelting, coal combustion, arsenical pesticides, and wood preservatives (Welch and Stollenwerk, 2003). In addition, mining for copper, gold, and other metals can increase the rate of dissolution of natural arsenic-bearing minerals (Smedley and Kinniburgh, 2002).

The MCL-US for arsenic was lowered from $50 \mu \mathrm{g} / \mathrm{L}$ to $10 \mu \mathrm{g} / \mathrm{L}$ in 2002; chronic exposure to arsenic concentrations between $10 \mu \mathrm{g} / \mathrm{L}$ and $50 \mu \mathrm{g} / \mathrm{L}$ in drinking water has been linked to increased cancer risk and to non-cancerous effects including skin damage and circulatory problems (U.S. Environmental Protection Agency, 2001). An estimated 8 percent of groundwater resources used for drinking water in the United States have high RCs of arsenic (greater than $10 \mu \mathrm{g} / \mathrm{L}$; Focazio and others, 2000; Welch and others, 2000), and high concentrations of arsenic in groundwater resources used for drinking water are a worldwide concern (Smedley and Kinniburgh, 2002; Welch and others, 2006).

Arsenic was present at high RCs in 7.2 percent of the shallow aquifer system and at moderate RCs in an additional 15 percent (table 7). The proportion of the shallow aquifer system having high RCs of arsenic was significantly greater in the Valleys and Plains study area (23 percent) than in the Highlands study area (0 percent; table 7, fig. 10). Previous investigations and a review of elevated arsenic in groundwater have identified two primary mechanisms for arsenic mobilization related to the observed conditions at sampled sites: (1) desorption from, or inhibition of sorption to, aquifer materials at elevated $\mathrm{pH}$ levels, and (2) release of arsenic from dissolution of iron or manganese oxyhydroxides under iron- or manganese-reducing conditions (Smedley and Kinniburgh, 2002; Belitz and others, 2003; Welch and others, 2006; Kulongoski and others, 2010; Fram and Belitz, 2012). The first mechanism described requires $\mathrm{pH}$ values to be greater than 7.8 , the level above which the primary arsenate species, $\mathrm{HA}_{\mathrm{S}} \mathrm{O}_{4}^{-2}$, is relatively soluble (Smedley and Kinniburgh, 2002). In addition to geochemical conditions, the accumulation of elevated arsenic concentrations in groundwater also requires favorable hydrologic conditions. Long contact times between groundwater and aquifer materials increases the reaction time with aquifer materials (Smedley and Kinniburgh, 2002).
In the NSF-SA, high and moderate RCs of arsenic were detected primarily in sites in the Valleys and Plains study area (fig. 11A). High RCs of arsenic were detected in anoxic groundwater (dissolved oxygen, or DO, less than $1 \mathrm{mg} / \mathrm{L}$ ) with reducing conditions and water classified as pre-modern or mixed (fig. 12; table 4). Only five samples had moderate concentrations of arsenic in groundwater classified as oxic or modern. Arsenic concentrations had a weak, but significant, negative correlation with DO (table 8). Only seven sites had $\mathrm{pH}$ values greater than 7.8, and only one of those sites had a high RC of arsenic. Mobilization of arsenic that led to high $\mathrm{RCs}$ of arsenic appeared to be primarily related to reducing conditions in the aquifer system, notably in the Valleys and Plains study area.

Hydrothermal waters can be a source of arsenic in some areas of the NFS-SA. Mineral solubility tends to increase with temperature, and thermal waters are often characterized as having elevated concentrations of trace elements like arsenic, boron, and fluoride (Hem, 1985). Notable geothermal systems in the NSF-SA include the Napa Valley-Calistoga hydrothermal system and the Sonoma Valley hydrothermal system (fig. 11A geothermal sites). Forrest and others (2013) investigated the mixing of relatively shallow groundwater with deeper hydrothermal fluids from these systems using USGS-GAMA data collected in 2004 for the NSF-PA assessment. They showed that groundwater that was mixing with hydrothermal water generally contained elevated concentrations of fluoride and arsenic (Forrest and others, 2013). The hydrothermal waters in these systems appear to ascend along faults or fracture zones, where they then mix with groundwater (Youngs and others, 1983; Farrar and others, 2006). Farrar and others (2006) investigated thermal waters in the Sonoma Valley and suggested that they could be affecting a broad area of the southern Sonoma Valley. Water temperatures in sites in the NSF-SA ranged from 12 to $26^{\circ} \mathrm{C}$ (mean $18^{\circ} \mathrm{C}$ ). The mean annual air temperature in the central part of the study unit was about $15^{\circ} \mathrm{C}$, which generally was similar to shallow groundwater temperatures. Sites in the NSF-SA with the highest concentrations of arsenic (greater than $20 \mu \mathrm{g} / \mathrm{L}$ ) were all where water temperatures were about equal to or greater than $20^{\circ} \mathrm{C}$. A geothermal resources study done for Napa and Sonoma Counties defined any water warmer than $20^{\circ} \mathrm{C}$ as thermal (California Division of Mines and Geology, 1984). Given the work by Forrest and others (2013), Farrar and others (2006), and the association of the highest concentrations of arsenic with elevated water temperatures in the USGS-GAMA samples discussed here, there is very likely a link between elevated concentrations of arsenic and the mixing of thermal waters with shallow groundwater in the NSF-SA. 
$\boldsymbol{A}$

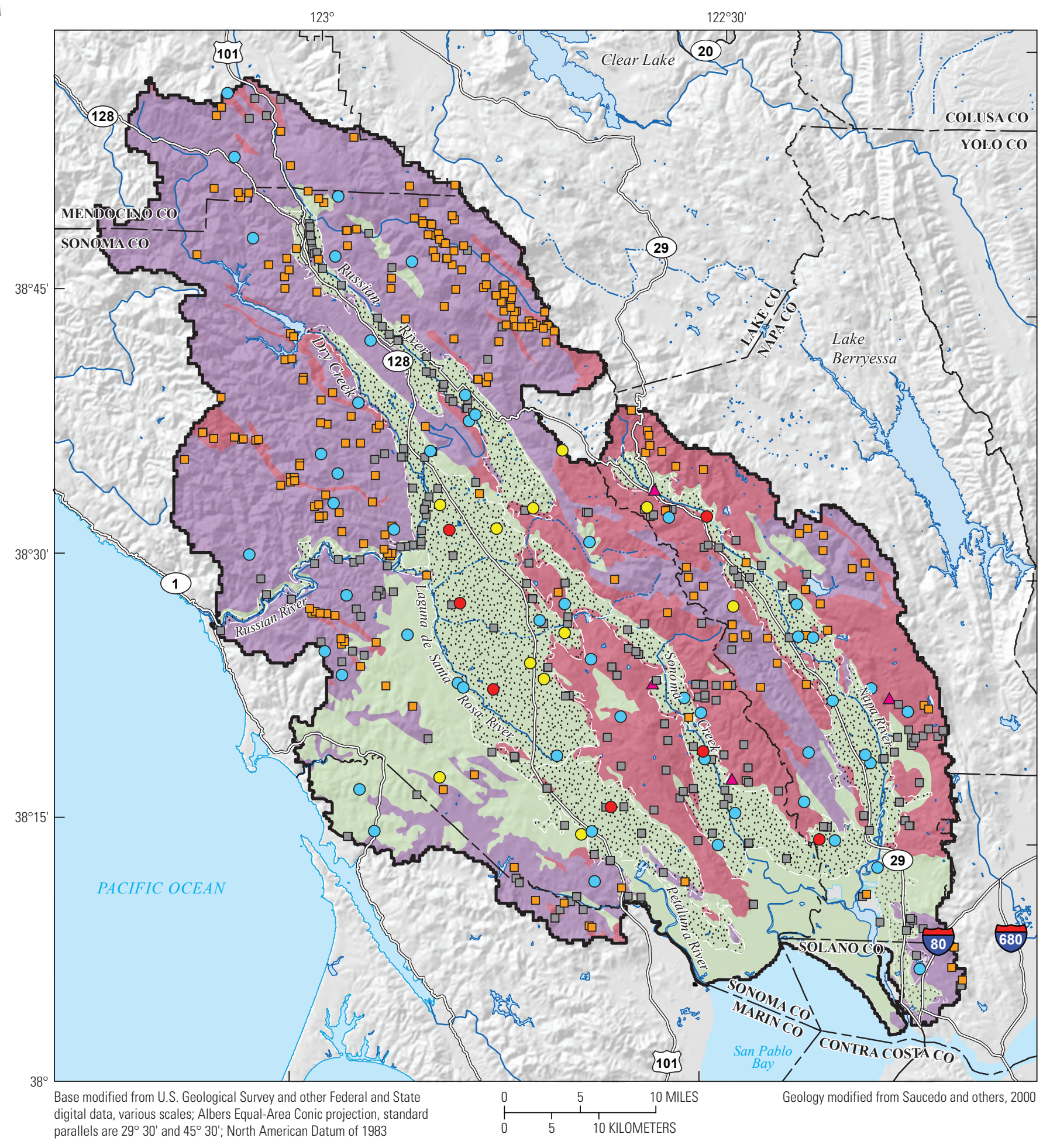
parallels are $29^{\circ} 30^{\prime}$ and $45^{\circ} 30^{\prime}$; North American Datum of 1983

EXPLANATION
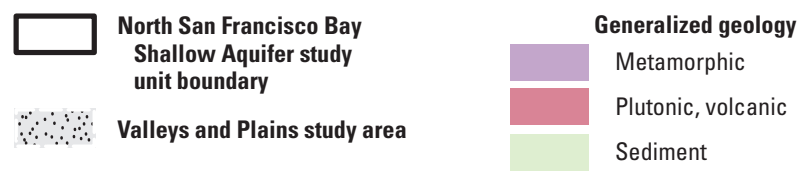

Arsenic relative-concentration category

Low

Moderate

High

Figure 11. Relative concentrations of selected trace elements in samples from U.S. Geological Survey grid sites, North San Francisco Bay Shallow Aquifer study unit (NSF-SA), 2012, California Groundwater Ambient Monitoring and Assessment (GAMA) Program Priority Basin Project: $A$, Arsenic; $B$, boron; and $C$, manganese. (Relative concentration refers to a ratio of the measured concentration to waterquality benchmark concentration for the specified constituent.) 


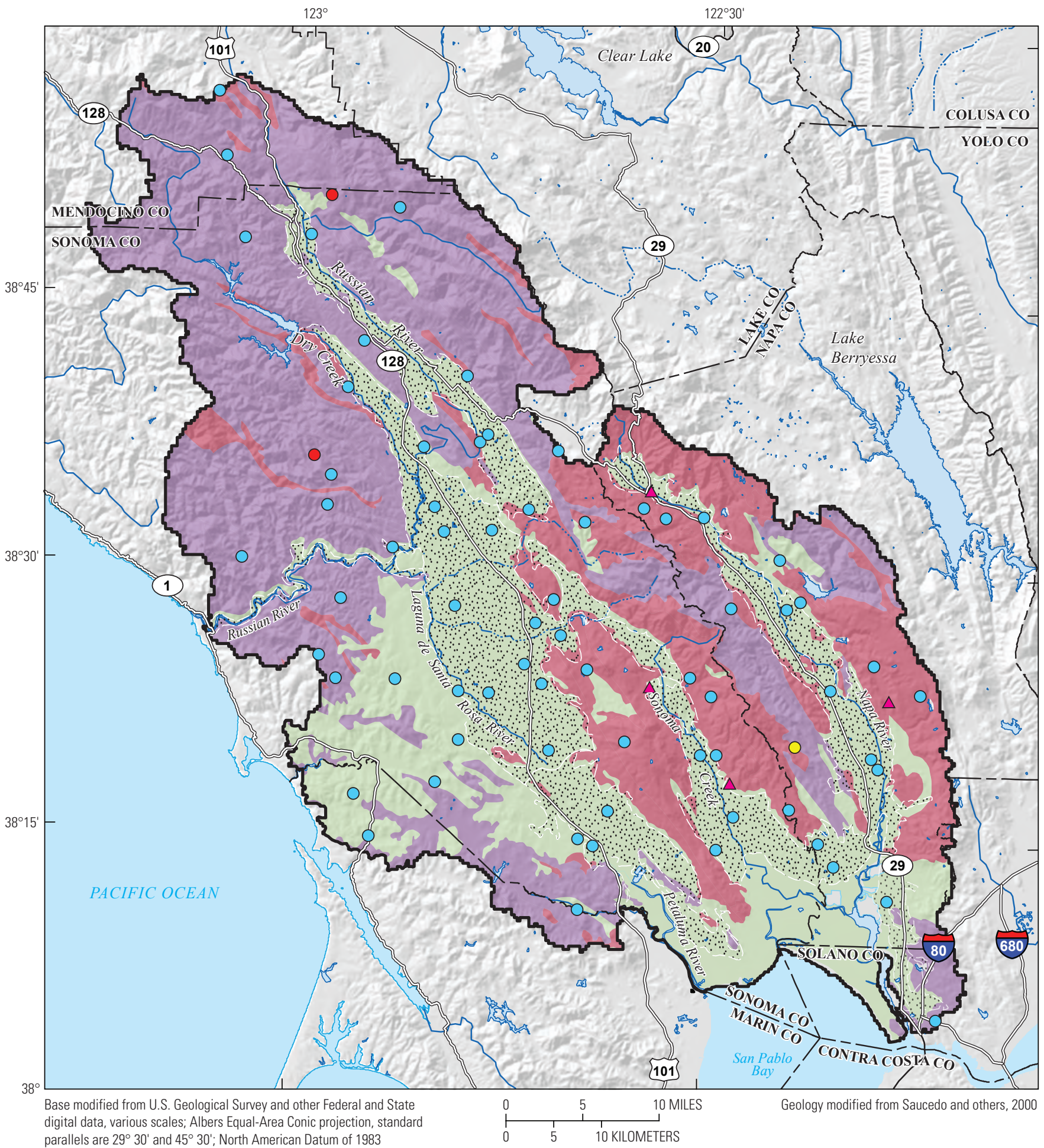
parallels are $29^{\circ} 30^{\prime}$ and $45^{\circ} 30^{\prime}$; North American Datum of 1983

EXPLANATION

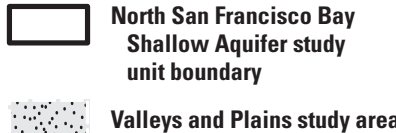

$\therefore \quad$ Valleys and Plains study area
Generalized geology

Metamorphic

Plutonic, volcanic

Sediment
Boron relative-concentration category

Low

Moderate

High

Figure 11. - - Continued 
C

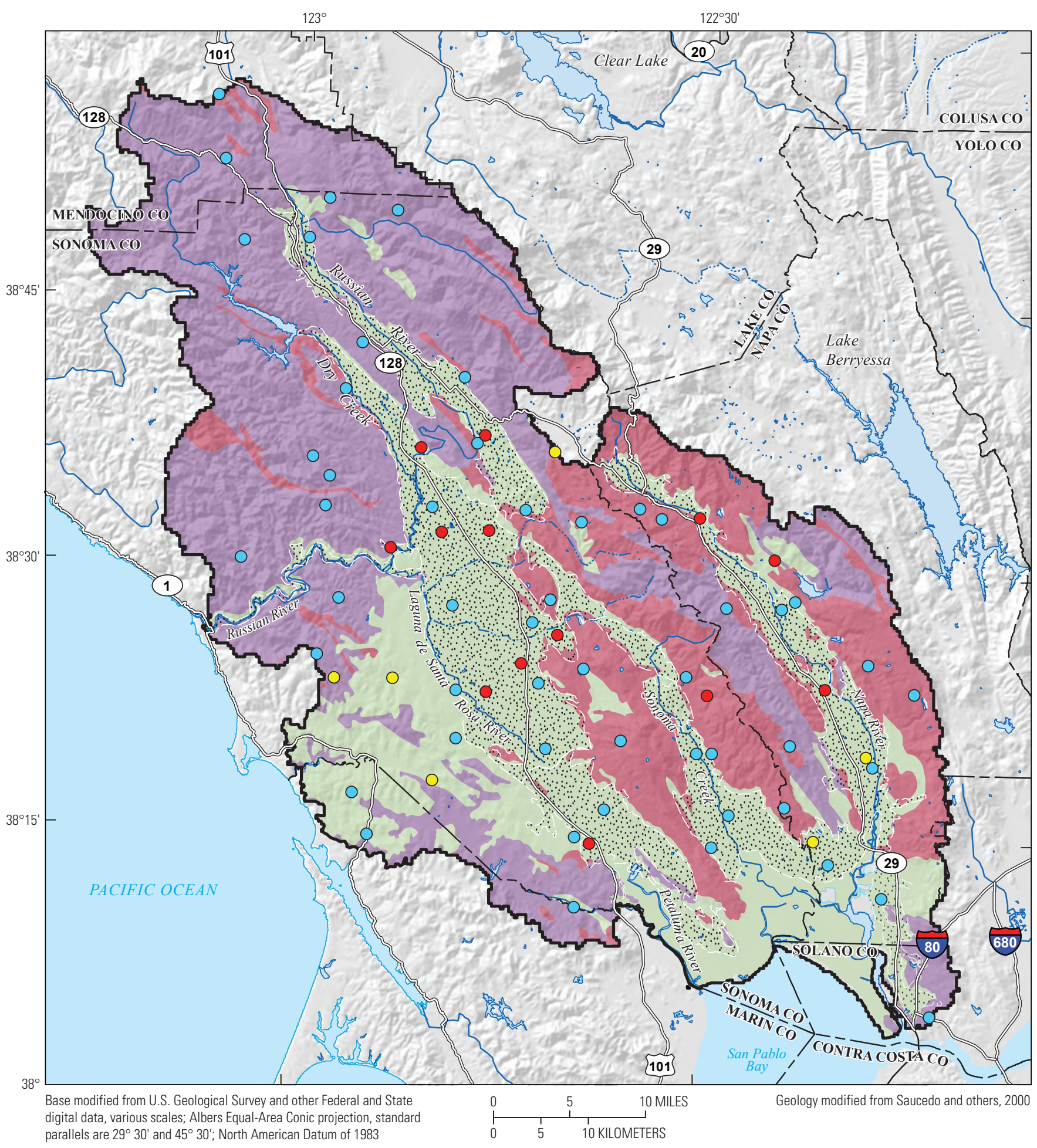

parallels are $29^{\circ} 30^{\prime}$ and $45^{\circ} 30^{\prime}$; North American Datum of 1983

\section{EXPLANATION}

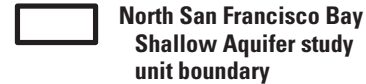

$\therefore \quad$ Valleys and Plains study area
Generalized geology

Metamorphic

Plutonic, volcanic

Sediment

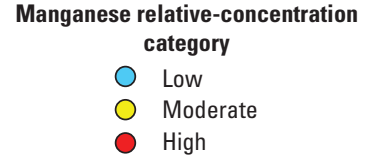

Manganese relative-concentration

Low

Moderat

Figure 11. - Continued 


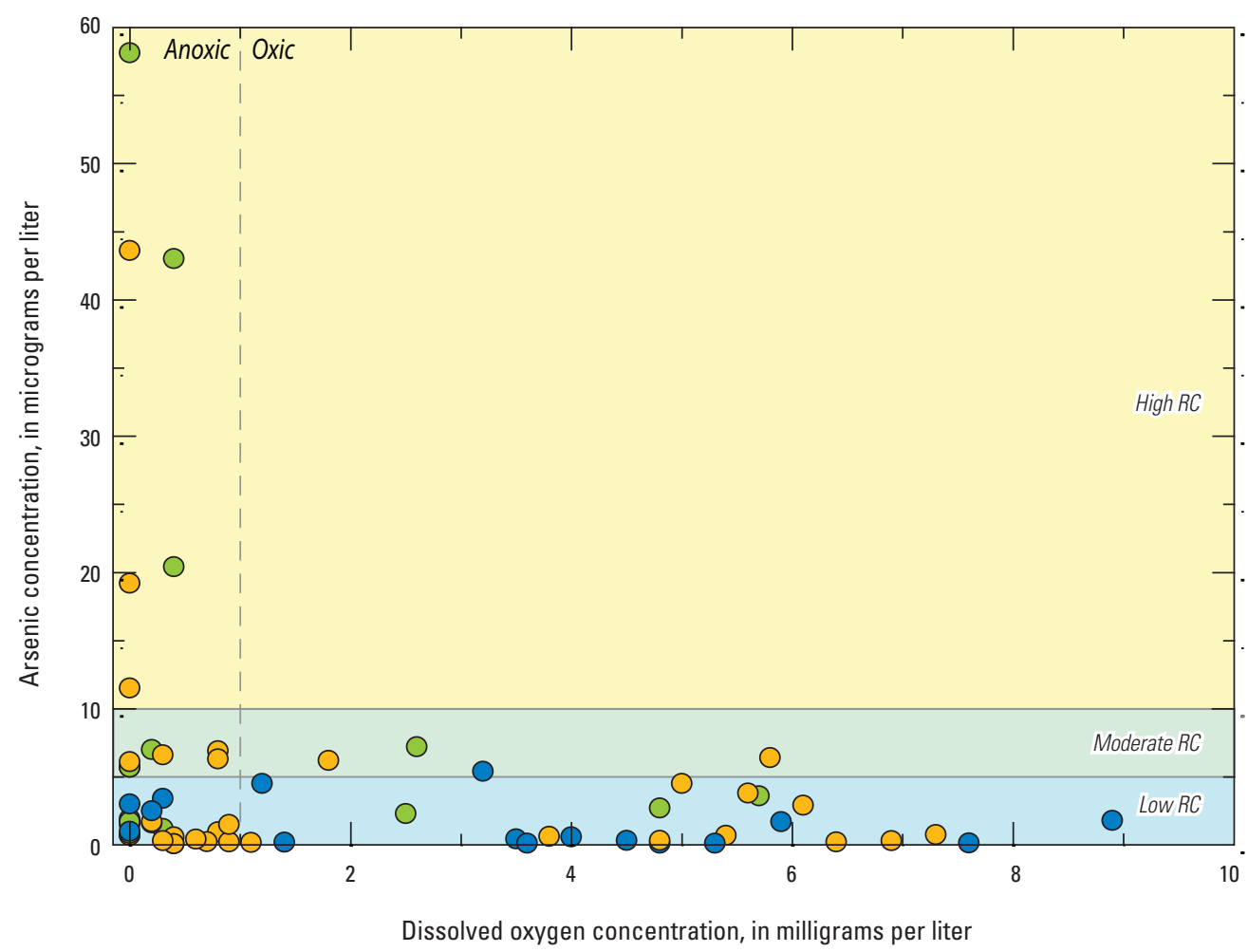

\section{EXPLANATION}

Groundwater age class

Pre-modern

Mixed

Modern

Figure 12. Relation of arsenic concentration to dissolved oxygen concentration and groundwater age class, North San Francisco Bay Shallow Aquifer study unit (NSF-SA), 2012, California Groundwater Ambient Monitoring and Assessment (GAMA) Program Priority Basin Project. (Relative concentration, or RC, refers to a ratio of the measured concentration to water-quality benchmark concentration for the specified constituent.)

Historical mining for copper, gold, mercury, or other metals and inorganic arsenical pesticide applications in the study unit are potential sources of arsenic in groundwater. A retrieval of the locations of mining operations throughout the study unit from the USGS Mineral Resources Data System (MRDS) showed mining operations for various metals were primarily in the Highlands study area (U.S. Geological Survey, 2005; fig. 11A). High RCs of arsenic were only seen in the Valleys and Plains study area and are likely unrelated to mining operations in the Highlands area of the study unit. A query of the California Department of Pesticide Regulation's Pesticide Use Reporting database for applications between 1974 and 1980 in Napa and Sonoma Counties did show limited applications of arsenic trioxide, lead arsenate, sodium arsenate, and sodium metaarsenite (California Department of Pesticide Regulation, 2015). These arsenical pesticides were generally used as insecticides or in the case of sodium metaarsenite as a fungicide on grapes (U.S. Environmental Protection Agency, 1972); however, applications of arsenical pesticides were phased out of use in the United States in the 1980s (Loebenstein, 1994). Given its generally limited application and its use having been phased out in the 1980s, high RCs of arsenic in groundwater are unlikely to be related to arsenical pesticide applications.

\section{Boron}

Boron is a naturally present semi-metallic element that is highly soluble in water. Natural sources of boron include dissolution of evaporate minerals, such as borax, ulexite, and colemanite, and boron-bearing silicate minerals, such as tourmaline, that are primarily found in igneous rocks (Hem, 1985; Klein and Hurlbut, 1993). Seawater contains approximately $4,500 \mu \mathrm{g} / \mathrm{L}$ of boron; thus, interactions with marine sediments, connate fluids, or seawater also can be natural sources of boron to groundwater (Hem, 1985). Boron also is associated with thermal springs and volcanic activity. Boron can be detected in wastewater because borax is a component of some detergents. Other anthropogenic uses of boron include the manufacture of glass and ceramics, fire retardants, and agricultural products. Boron is an essential nutrient for plants, but is toxic to plants at high concentrations. The comparison benchmark used for boron in this study was the HBSL of $6,000 \mu \mathrm{g} / \mathrm{L}$, which is equal to the HAL-US. High concentrations of boron can adversely affect fetal development (U.S. Environmental Protection Agency, 2008).

Boron was present at high RCs in 3.5 percent of the shallow aquifer system and at moderate RCs in 1.7 percent (table 7). High and moderate RCs of boron were only detected in the Highlands study area (fig. 10A). 
Boron concentrations were significantly negatively correlated with DO concentrations and also significantly positively correlated with $\mathrm{pH}$ (table 8 ). Sites classified as anoxic had higher concentrations of boron than the other redox classes (table 4). While high and moderate RCs of boron were only detected in the Highlands study area, median boron concentration was significantly higher in the Valleys and Plains study area and in samples from the sedimentary, as opposed to volcanic, aquifer lithology (table 4). Boron concentrations were also significantly positively correlated with chloride, fluoride, and TDS (table 9).

Elevated concentrations of boron have been commonly associated with groundwater connected with geothermal activity (as are arsenic and fluoride), connate waters from older marine formations associated with fault zones or evaporate deposits, and the Sonoma Volcanic deposits in the Napa and Sonoma areas (Cardwell, 1958; Farrar and others, 2006; Kulongoski and others, 2010; Forrest and others, 2013). As with arsenic, two hydrothermal systems in the NSF-SA, the Napa Valley-Calistoga system and the Sonoma Valley system near Agua Caliente, Calif. (not shown on map), were shown by Forrest and others (2013) to be contributing deep hydrothermal water to fresh groundwater in the public-supply aquifer system through faults near these geothermal systems. The sites with the highest concentrations of boron in the NSF-SA were those close to fault lines (fig. 4); however, they were not near either of the hydrothermal systems examined by Forrest and others (2013; fig. 11B). The sedimentary rocks in the NSF-SA have a large component of marine-derived sediments, including some that have been altered through metamorphism. Both sites with high concentrations of boron were in the Franciscan Complex, a highly deformed and metamorphosed collection of rocks predominantly composed of marine-derived sediments.

\section{Fluoride}

Fluoride is the anion form of the element fluorine. Natural sources of fluoride in groundwater include dissolution of fluoride-bearing minerals, such as fluorite, $\mathrm{CaF}_{2}$, and fluorapatite, $\mathrm{Ca}_{5}\left(\mathrm{PO}_{4}\right)_{3}(\mathrm{~F}, \mathrm{OH})$. The main anthropogenic source of fluoride to water is the addition of sodium fluoride or hexafluorosilicic acid during drinking-water treatment as a public health measure to reduce dental caries (cavities). The MCL-CA for fluoride, $2 \mathrm{mg} / \mathrm{L}$, is lower than the MCL-US for fluoride, $4 \mathrm{mg} / \mathrm{L}$.

Fluoride was detected at high RCs in 3.5 percent of the shallow aquifer system and at moderate concentrations in 1.7 percent (table 7). Like boron, high and moderate RCs of fluoride were only detected in the Highlands study area (fig. 10A).

Fluoride concentrations were significantly higher in pre-modern and mixed age groundwater than in groundwater classified as modern and were also greater in groundwater classified as anoxic than in oxic groundwater (table 4). Concentrations of fluoride were positively correlated with depth to top of screened or open interval and $\mathrm{pH}$ values (table 8), and with concentrations of TDS (table 9). Fluoride concentrations were negatively correlated with DO concentrations (table 8).

Elevated concentrations of fluoride in groundwater typically are associated with long residence times and alkali granitic rocks and metamorphic rocks (Nordstrom and others, 1989; Kim and Jeong, 2005). In general, the minerals that contain fluoride have relatively low solubility (Hem, 1985). Those minerals are commonly associated with igneous rocks, but are also found in sedimentary rocks. Fluoride solubility in groundwater is primarily related to concentrations of calcium. Groundwater with higher calcium concentrations is likely to be in equilibrium with fluorite, thus limiting its solubility (Hem, 1985). Therefore, it is more likely that higher concentrations of fluoride are in older groundwater that has low calcium concentrations. Calcium concentrations in groundwater are generally lowered through cation exchange and the precipitation of minerals, such as calcium carbonate, onto aquifer materials over time. Given an extended residence time of groundwater in the aquifer, cation exchange processes can result in increased sodium and decreased calcium ratios. In the NSF-SA, the two sites with high concentrations of fluoride and the one with a moderate concentration all were in groundwater with low relative proportions of calcium (as a percentage of total cations) that were identified as mixed with respect to groundwater age (fig. 13).

\section{Manganese}

Manganese, a metallic element, is naturally present, and its concentrations in groundwater are strongly influenced by oxidation-reduction (redox) conditions in the aquifer. Many igneous and metamorphic rocks and minerals contain manganese, and it is a primary constituent of basalt (a mafic rock type) and mafic minerals (Hem, 1985). The comparison benchmark used for manganese in this study was the HBSL of $300 \mu \mathrm{g} / \mathrm{L}$, which is equal to the EPA lifetime health advisory level (HAL-US). There is also an SMCL-CA for manganese of $50 \mu \mathrm{g} / \mathrm{L}$ and an NL-CA of $500 \mu \mathrm{g} / \mathrm{L}$. The SMCL-CA is established at the concentration at which manganese can affect the aesthetic properties of water, but has negligible adverse health effects. 


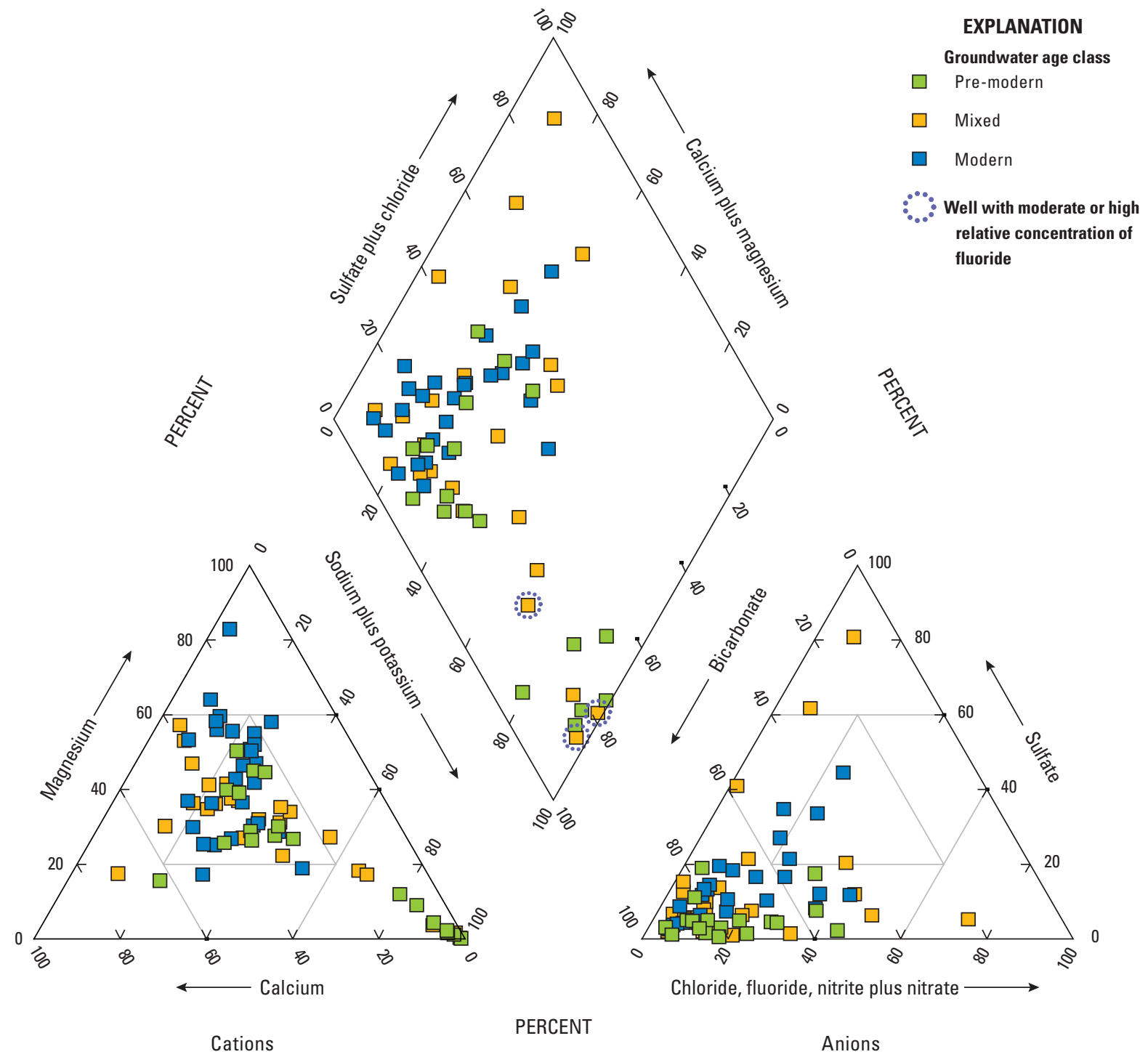

Figure 13. Relative ionic composition, water types, and groundwater age classifications in U.S. Geological Survey grid sites, North San Francisco Bay Shallow Aquifer study unit (NSF-SA), 2012, California Groundwater Ambient Monitoring and Assessment (GAMA) Program Priority Basin Project.

Manganese was detected at high RCs in 15 percent of the shallow aquifer system and at moderate RCs in 8.9 percent (table 7). Manganese concentrations were detected at high and moderate RCs in the Highlands and, more notably, in the Valleys and Plains study areas (fig. 10A). The proportion of the shallow aquifer system with high RCs of manganese was significantly greater in the Valleys and Plains study area (33 percent) than the proportion in the Highlands study area (7.5 percent; table 7).

Manganese concentrations were significantly higher in groundwater with anoxic redox conditions than in groundwater classified as oxic (table 4). Manganese concentrations were also significantly higher in the Valleys and Plains study area and in samples from sedimentary aquifer lithology (table 4; fig. 11C). Manganese concentrations were negatively correlated with percentage of natural land use; elevation; and, most strongly, with DO concentrations (table 8). The negative correlation with DO concentration is consistent with the dissolution of manganese from aquifer materials under reducing conditions. This is the same process that was attributed to arsenic mobilization in the Valleys and Plains study area. It was also identified as the process responsible for the mobilization of iron. 


\section{Nutrients}

Nutrients, as a class, were present at high RCs in 2.1 percent of the shallow aquifer system and were present at moderate RCs in 2.7 percent of the shallow aquifer system (table 6A). Nitrate was the nutrient present at high and moderate RCs (table 7). Nitrate has anthropogenic and natural sources to groundwater; however, concentrations greater than $2 \mathrm{mg} / \mathrm{L}$ as nitrogen (relative concentration of 0.2 ) generally are considered to indicate presence of nitrate from anthropogenic sources (Mueller and Helsel, 1996).

Nitrate concentrations were significantly higher in samples from the sedimentary aquifer lithology than in samples from the metamorphic aquifer lithology, and the high RCs were detected only in the Valleys and Plains study area (table 4; fig. 14). Concentrations of nitrate were significantly negatively correlated with the percentage of natural land use, aridity index, and $\mathrm{pH}$, and they were significantly positively correlated with the percentage of urban land use and UST density (table 8). Nitrate concentrations were also significantly positively correlated with vanadium and perchlorate and significantly negatively correlated with iron and manganese concentrations (table 9).

The significant positive correlations of nitrate concentration with urban land use is consistent with anthropogenic activities as the source of increased nitrate concentrations (Landon and others, 2011). Nitrate concentrations in the NSF-SA were also strongly positively correlated to perchlorate. Of the two samples with detections of nitrate at high RCs, one had a perchlorate concentration greater than $1.5 \mu \mathrm{g} / \mathrm{L}$, and the other $0.38 \mu \mathrm{g} / \mathrm{L}$. A broader discussion of the association between nitrate and perchlorate concentrations is presented in the "Perchlorate" section.

\section{Constituents with SMCL Benchmarks}

Constituents with aesthetic-based benchmarks (SMCLs), as a class, had high RCs (for one or more constituents) in 24 percent of the shallow aquifer system, moderate values in 16 percent, and low values in 60 percent (table $6 A$ ). Iron, sulfate, and TDS were the constituents with high RCs in the grid-site network (table 7). The major ions chloride, sulfate, and TDS have recommended and upper SMCL-CA values. In this report, data were compared to the upper SMCL-CA values. Sulfate and TDS had high RCs in 1.7 percent and 5.5 percent of the shallow aquifer system, respectively (table 7). Chloride was detected at moderate RCs in 2.1 percent of the shallow aquifer system (table 7).

Iron

Natural sources of iron to groundwater include weathering and dissolution of minerals in soils, sediments, and rocks. Iron oxyhydroxide minerals are commonly coatings on mineral and sediment grains. In addition, iron-bearing silicate, sulfide, or oxide minerals are in most rocks and sediments. The solubility of iron is strongly dependent on oxidationreduction conditions; the more reduced species are much more soluble than oxidized ones (McMahon and Chapelle, 2008).

The trace element iron was detected at high concentrations in 20 percent of the shallow aquifer system and at moderate concentrations in 4.8 percent of the shallow aquifer system (table 7). Unlike manganese, the proportion of the shallow aquifer system with high RCs of iron did not differ between the two study areas.

Iron concentrations were significantly positively correlated with chloride, manganese, TDS, and sulfate and were significantly negatively correlated with nitrate, vanadium, and perchlorate (tables 8,9 ). Iron concentrations were also significantly higher in samples from sites classified as anoxic than in samples classified as oxic (table 4).

Reducing conditions in alluvial aquifers (Valleys and Plains study area) typically are produced by consumption of DO by oxidation of sedimentary organic matter (Appelo and Postma, 2005). Reducing conditions in aquifers not containing, or with minimal, organic matter, similar to the hard-rock aquifers of the Highlands study area, can be produced by reactions with minerals containing ferrous $\left(\mathrm{Fe}^{+2}\right)$ iron, given sufficiently long residence times (Gascoyne, 1997; Sidborn and Neretnicks, 2007; Fram and Belitz, 2012). In the NSF-SA, anoxic or mixed conditions were found in 62 percent of the sites sampled. The sedimentary and metamorphic aquifer lithology classes were associated with the greatest number of sites identified as having anoxic or mixed redox conditions. Minerals containing ferrous iron, such as biotite, chlorite, magnetite, pyrite, and hornblende, are commonly present in the metamorphic rocks observed in the NSF-SA; this lithology type makes up a large proportion of the Highlands study area (Weaver, 1949; Cardwell, 1958).

\section{Total Dissolved Solids, Chloride, and Sulfate}

Natural sources of TDS to groundwater include weathering and dissolution of minerals in soils, sediments, and rocks; mixing with saline or brackish waters from the ocean, estuaries, or saline lakes; interactions with marine or lacustrine sediments; mixing with hydrothermal solutions; and concentration by evapotranspiration of shallow groundwater (Hem, 1985). Anthropogenic sources of TDS to groundwater include recharge of water used for irrigation, wastewater discharges, and evaporation (Hem, 1985). Total dissolved solids were present at high RCs in 5.5 percent of the NSF-SA and at moderate RCs in 16 percent, and the proportions were not significantly different between the two study areas (table 7). Chloride and sulfate are both components of TDS. The two sites with high RCs of TDS in the Highlands study area also had high or moderate RCs of sulfate, whereas the two sites with high RCs of TDS in the Valleys and Plains study area had moderate RCs of chloride. 


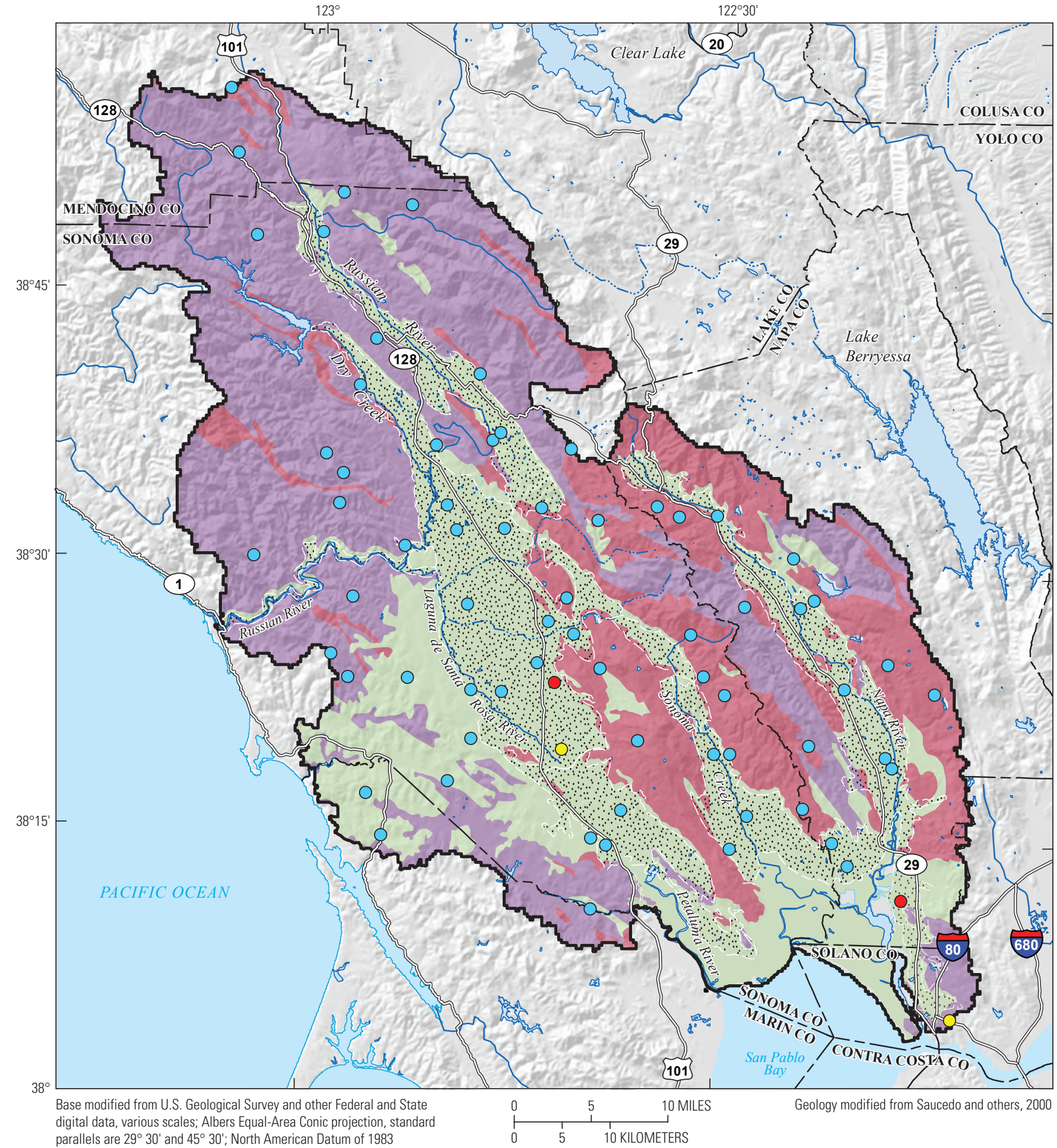

EXPLANATION
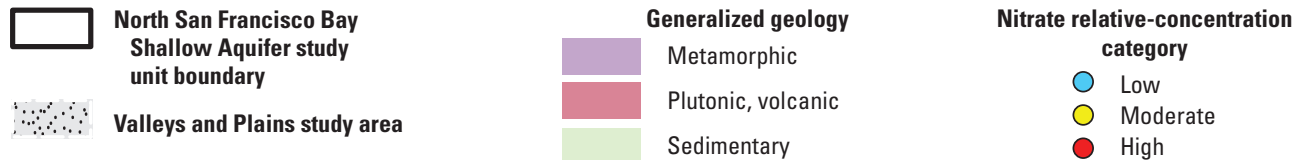

Figure 14. Relative concentrations of nitrate in samples from U.S. Geological Survey grid sites, North San Francisco Bay Shallow Aquifer study unit (NSF-SA), 2012, California Groundwater Ambient Monitoring and Assessment (GAMA) Program Priority Basin Project. (Relative concentration refers to a ratio of the measured nitrate concentration to water-quality benchmark concentration for nitrate.) 
Total dissolved solids concentrations were higher in groundwater classified as anoxic than in samples classified as oxic (table 4). In terms of aquifer lithology, TDS concentrations were higher in samples from the sedimentary lithology than from the volcanic lithology class, and TDS concentrations also were higher in the Valleys and Plains study area than in the Highlands study area (table 4).

Total dissolved solids concentrations were significantly positively correlated with boron, chloride, fluoride, iron, manganese, $\mathrm{pH}$, strontium, sulfate, and percentage of urban land use (tables 8,9). Concentrations of TDS were significantly negatively correlated with aridity index, elevation, percentage of natural land use, and DO (table 8). The observed correlations highlight the fact that many of the explanatory factors are concomitant with either the Valleys and Plains or Highlands study areas and that TDS concentrations are generally higher in the Valleys and Plains study area than in the Highlands. The Sonoma County Water Agency (SCWA) detailed sources of TDS in the Sonoma Valley in its "Salt and Nutrient Management Plan" (Sonoma County Water Agency, 2013). Their report shows that TDS loading in the Sonoma Valley outside of the areas known to have historically brackish water owing to proximity to San Pablo Bay (an area they define as the Baylands) is primarily related to a number of different land uses including vineyards, pasture, urban residential, and farmsteads/rural residential (Sonoma County Water Agency, 2013).

\section{Organic and Special-Interest Constituents}

The organic constituent classes assessed in this study are volatile organic compounds (VOCs) and pesticides (including degradates). Although some VOCs are naturally present in association with hydrocarbon (natural gas and oil) deposits, their presence in groundwater in most areas outside oil and gas fields indicates an anthropogenic source. Volatile organic compounds can be present in paints, solvents, fuels, refrigerants, and fumigants or can be formed as byproducts of water disinfection. Volatile organic compounds are characterized by a volatile nature, or tendency to evaporate, and they generally persist longer in groundwater than in surface water because groundwater is more isolated from the atmosphere.

Pesticides are used to control weeds, fungi, or insects in agricultural and urban settings. The only special-interest constituent evaluated in the NSF-SA was perchlorate. Perchlorate, an inorganic salt with natural and anthropogenic sources, was considered a constituent of special interest when the GAMA Priority Basin Project began in 2001 because it had been observed in, or was considered to have the potential to reach, drinking-water supplies (California State Water Resources Control Board, 2007). An MCL-CA for perchlorate of $6 \mu \mathrm{g} / \mathrm{L}$ became effective in October 2007 (California State Water Resources Control Board, 2015b). Despite being a naturally present inorganic constituent, perchlorate is discussed with the organic constituents because concentrations near or above the MCL-CA are typically from an anthropogenic source (California State Water Resources Control Board, 2007).

One or more organic constituents were found in 29 of the 70 grid sites (41 percent) sampled in the study unit. Of the 148 organic constituents analyzed, 20 were detected in at least 1 site in the NSF-SA (tables 2, 3). Of these 20 constituents, 13 have regulatory health-based benchmarks. Organic constituents were present at high RCs in 1.0 percent of the NSF-SA, but were not measured in any samples at moderate RCs (table 6B). The only organic constituent present at high RC was the insecticide dieldrin, and the only organic constituent detected in greater than 10 percent of the grid-site samples was the disinfection byproduct chloroform (table 2; fig. 15). The insecticide dieldrin was detected in the sample from only one site in the NSF-SA, but it was detected at a high RC in the Valleys and Plains study area (fig. 16B). Dieldrin was a widely used insecticide from 1950 to 1974, before most of its uses were banned in 1984 (Agency for Toxic Substances and Disease Registry, 2002). Insecticide detections in groundwater are relatively rare; however, the most commonly detected insecticide in shallow groundwater in urban areas nationwide was dieldrin (Gilliom and others, 2006). Dieldrin is not very mobile in water, but its persistence and extensive historical use have resulted in detectable concentrations 5 to 15 years after its use was discontinued (Gilliom and others, 2006).

Benzene was reported at a high concentration in Bennett and Fram, 2014, but is not listed here as a constituent selected for inclusion in the status or understanding assessments. It was noted at the time of sampling that the well head where it was detected was in a subsurface vault inside a canvas shed used by the well owner to store a vehicle for an extended time. The vehicle was only a few feet away from the vault that housed the well head. It is suspected that this vehicle could have leaked oil or gasoline onto the ground surface, resulting in contamination of the well and explaining the suite of gasoline hydrocarbons detected (benzene, $o$-ethyl toluene, isopropylbenzene, naphthalene, styrene, and toluene). Given these circumstances, it is suggested that the results for organic constituents in this sample were not representative of the shallow aquifer for this grid cell, and therefore, these detections were not included in the assessments of groundwater for the NSF-SA. 


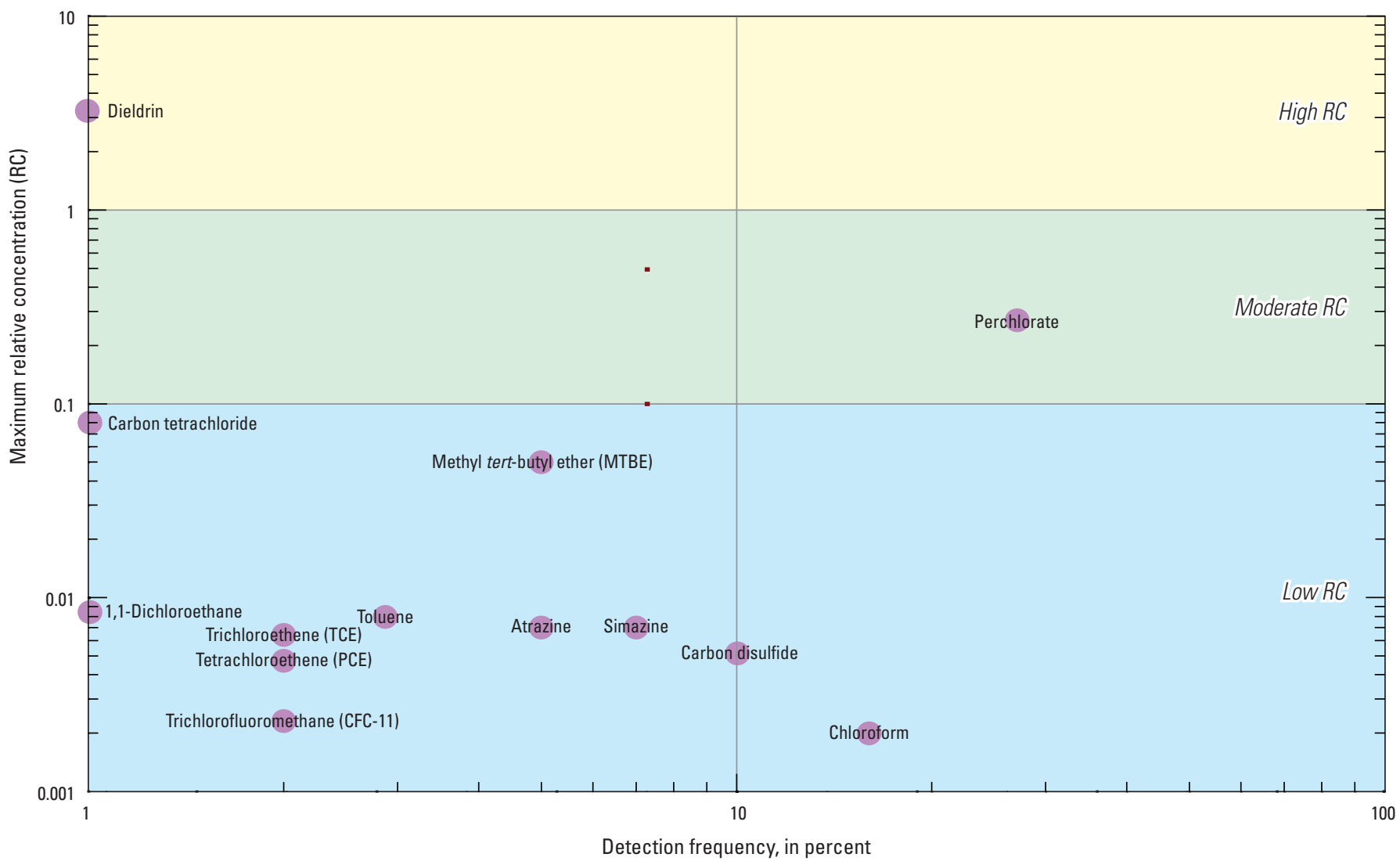

EXPLANATION

Atrazine Name and center of symbol is location of data unless indicated by the following leader line

Figure 15. Detection frequency and maximum relative concentration of organic and special-interest constituents detected in samples from U.S. Geological Survey grid sites, North San Francisco Bay Shallow Aquifer study unit (NSF-SA), 2012, California Groundwater Ambient Monitoring and Assessment (GAMA) Program Priority Basin Project. 


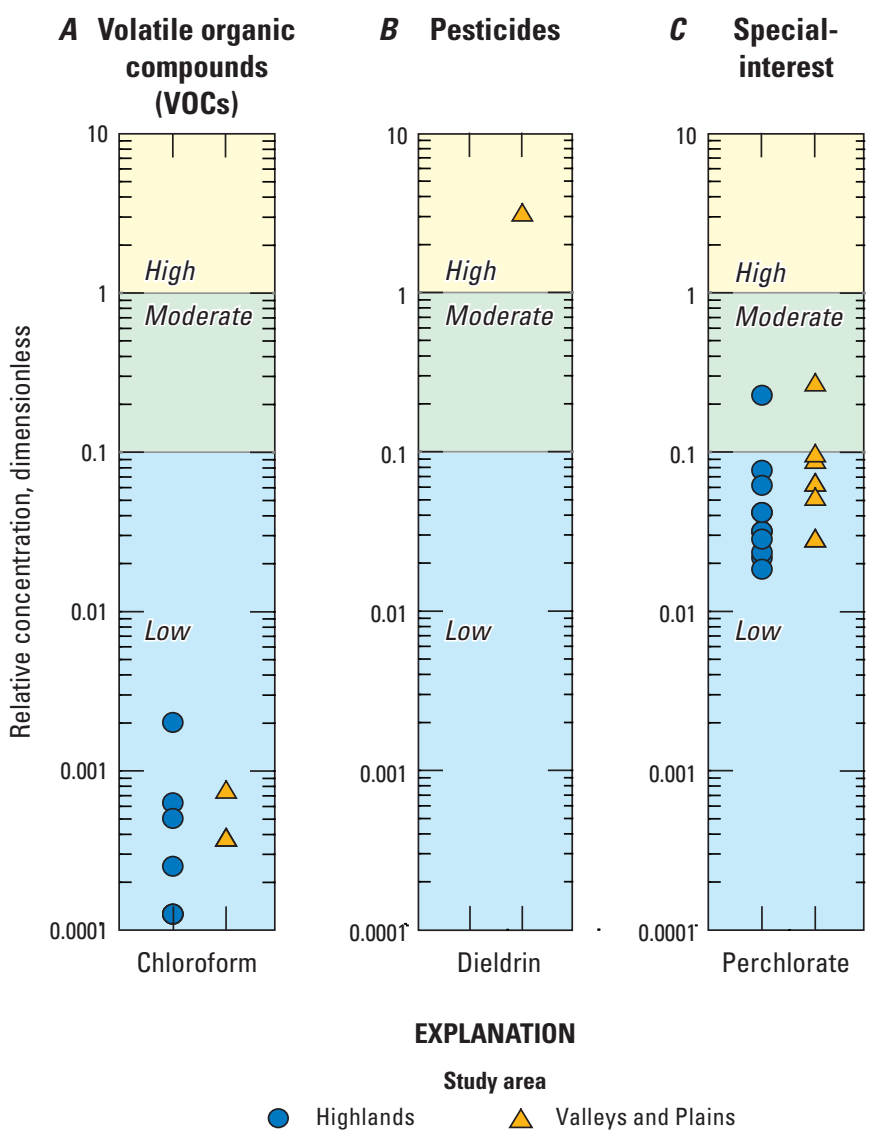

Figure 16. Relative concentrations of selected organic and special-interest constituents in samples from U.S. Geological Survey grid sites, North San Francisco Bay Shallow Aquifer study unit (NSF-SA), 2012, California Groundwater Ambient Monitoring and Assessment (GAMA) Program Priority Basin Project: $A$, VOCs; $B$, pesticides; and $C$, the special-interest constituent perchlorate.

\section{Chloroform}

The trihalomethane (THM) chloroform was the most commonly detected VOC in the NSF-SA, with a detection frequency of 16 percent (fig. 15). All detections were at low RCs (fig. 16A). This detection frequency was lower that what was reported by Bennett and Fram (2014) because two wells (S-NSF-H36 and S-NSF-VP01) were excluded from the calculations reported here, because these wells had been subjected to shock chlorination prior to sampling. Shock chlorination is a recommended procedure for the treatment of bacterial contamination and odor problems in domestic wells (Centers for Disease Control and Prevention and U.S. Department of Housing and Urban Development, 2006). Shock chlorination of wells can result in a reservoir of chlorinated water in the well bore and surrounding aquifer material (Centers for Disease Control and Prevention and U.S. Department of Housing and Urban Development, 2006).

Chloroform is among the most commonly detected VOCs in groundwater nationally (Zogorski and others, 2006). Water used for drinking water and other household uses in domestic and public-supply (municipal and community) systems commonly is disinfected with solutions that contain chlorine. In addition to disinfecting the water, the chlorine can react with organic matter to produce trihalomethanes (THMs) and other chlorinated or brominated disinfection byproducts.

Chloroform concentrations were higher in groundwater classified as modern than in samples classified as premodern with respect to groundwater age and higher in oxic than in anoxic redox conditions (table 4). Concentrations of chloroform were also positively correlated with UST density and dissolved oxygen (table 8). Even though the two wells known to have had shock chlorination were excluded from the statistical testing, well maintenance procedures could still have introduced chloroform, because other wells could have also been treated with chlorine solutions. The detection frequency of chloroform in public-supply aquifer study units generally has been greater than in the NSF-SA. The greater detection frequencies and significant correlations between chloroform concentration and urban land use or septic tank density found in many public-supply aquifers of GAMA Priority Basin Project study units (for example, Kulongoski and others, 2010; Landon and others, 2010; Fram and Belitz, 2012) could reflect that disinfection is more commonly used in public-supply wells than in domestic wells and that public-supply systems are more likely to use disinfection in more densely than less densely populated areas.

\section{Perchlorate}

Perchlorate was present at moderate RCs in 2.7 percent of the NSF-SA (table 7). The reporting limit for perchlorate was $0.1 \mu \mathrm{g} / \mathrm{L}$ (equivalent to an $\mathrm{RC}$ of 0.017 ), and perchlorate was detected at low RCs in 24 percent of the aquifer system (figs. 15, 16C).

Perchlorate concentrations showed similar patterns of correlations to potential explanatory factors as did nitrate concentrations. Perchlorate concentrations were significantly negatively correlated with aridity index, $\mathrm{pH}$, iron, and manganese (tables 8,9$)$ and significantly positively correlated with nitrate, vanadium, DO, and urban land use (tables 8,9).

Perchlorate has natural and anthropogenic sources to groundwater. It forms naturally in the atmosphere and is present in precipitation (Dasgupta and others, 2005; Parker and others, 2008; Rajagopalan and others, 2009). Potential anthropogenic sources include solid rocket fuel, explosives, some fertilizers, and flushing of salts from the unsaturated zone by irrigation (Dasgupta and others, 2005; U.S. Environmental Protection Agency, 2005). Following the methodology developed by Fram and Belitz (2011), observed detection frequencies of perchlorate at concentrations greater than specified threshold values $(0.1,0.5$, and $1 \mu \mathrm{g} / \mathrm{L})$ were compared to the predicted probability of perchlorate concentrations under natural conditions as a function of aridity index. Because perchlorate is reduced at about the same redox as nitrate, only samples that were either oxic or suboxic, or samples that were nitrate reducing and also had perchlorate detections, were included in the analysis. This screening 
process resulted in 48 samples that were divided into 3 groups: 17 Valleys and Plains study-area samples, 15 Highlands studyarea samples with high aridity-index values, and 16 Highlands study-area samples with low aridity-index values. Splitting the Highlands samples into high and low ranges was done simply by sorting them by aridity-index value and then dividing the sorted list into two nearly equal size groups. Detection frequencies of perchlorate were then calculated for each of the three groups. For example, of the 17 samples in the Valleys and Plains group, 8 had detections of perchlorate at concentrations greater than $0.1 \mu \mathrm{g} / \mathrm{L}$, equating to a 47 percent detection frequency (fig. 17). Detection frequencies of perchlorate in the Valleys and Plains study-area samples and the low aridity-index group of Highlands study-area samples were generally higher than predicted for natural conditions (fig. 17), indicating contribution of perchlorate from anthropogenic sources.

Perchlorate and nitrate concentrations were strongly correlated (Spearman's rho $=0.76, p$ less than 0.001 ) in the 48 samples used to compare observed perchlorate detection frequency with the probability of perchlorate detection above natural concentrations. Additionally, in 28 samples with non-detections of perchlorate, the detection frequency of any herbicide or herbicide degradate was 4 percent, whereas in 20 samples with detections of perchlorate, it was 37 percent. The difference in herbicide detection frequencies was significant (contingency table test $p=0.005$ ). These associations indicated an agricultural source of perchlorate.

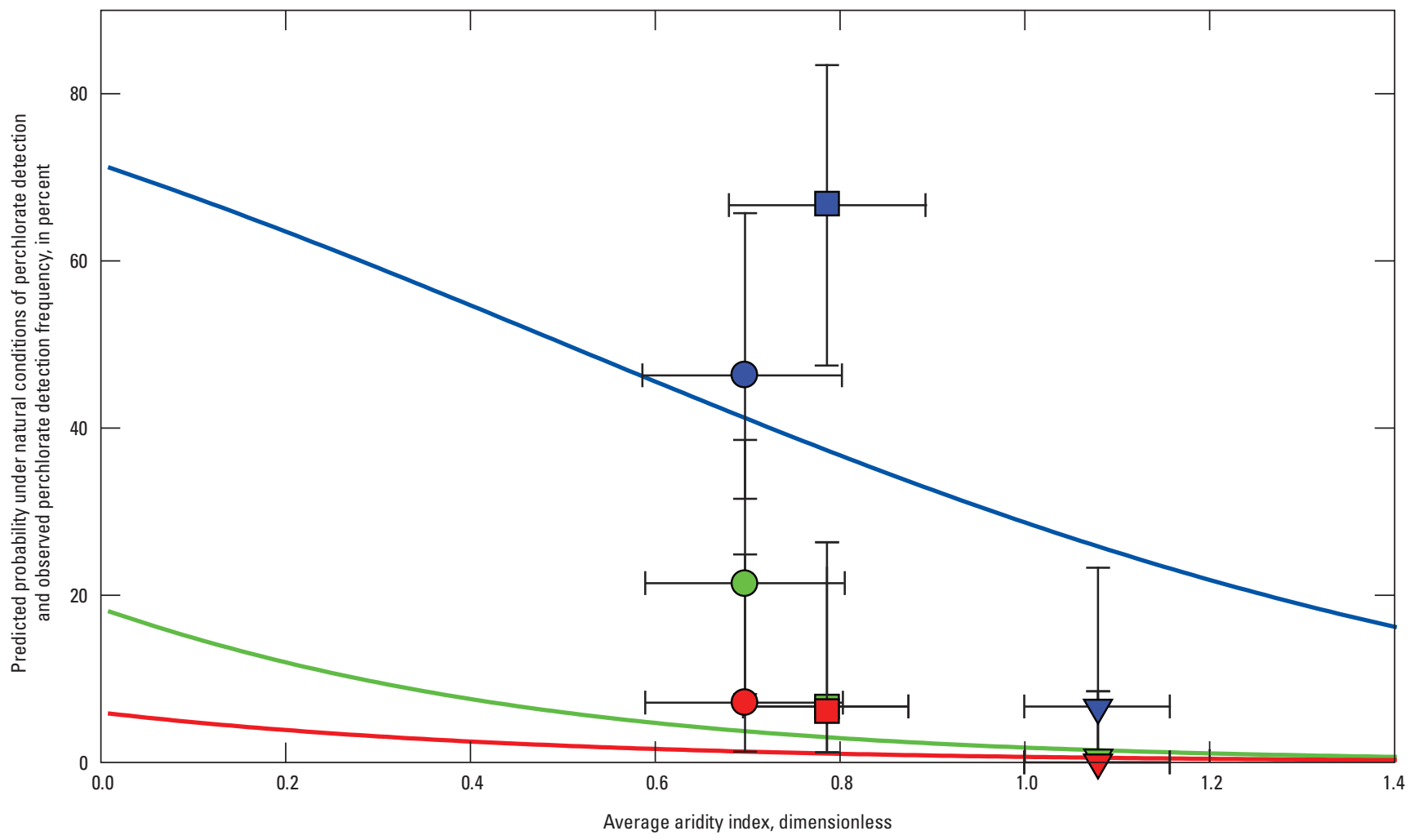

EXPLANATION

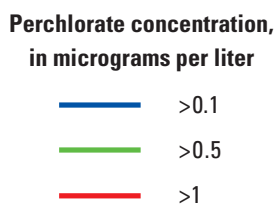

Observed detection frequency of perchlorate, in micrograms per liter

$\begin{array}{rlll}\text { Valleys and Plains } & >0.1 & >0.5 & >1 \\ \text { Highlands with low aridity index } & \square & \square \\ \text { Highlands with high aridity index } & \nabla & \square\end{array}$

The 48 U.S. Geological Survey grid sites with perchlorate data that were oxic or suboxic, or if nitrate reducing had measureable perchlorate, were divided into three groups. Horizontal error bars equal plus or minus one standard deviation of the average aridity index. Vertical error bars are the 90-percent Jeffreys confidence interval for the observed detection frequency.

Figure 17. Predicted probability under natural conditions of detecting perchlorate in groundwater as a function of aridity index and observed detection frequency and average aridity index grouped by specified threshold values, North San Francisco Bay Shallow Aquifer study unit (NSF-SA), 2012, California Groundwater Ambient Monitoring and Assessment (GAMA) Program Priority Basin Project. 
Two mechanisms by which agricultural activities can contribute perchlorate to groundwater are the addition of perchlorate found in some fertilizers and the remobilization of endemic perchlorate salts by irrigation. Perchlorate is a natural minor component of salts associated with nitrate fertilizer imported into the United States from the Atacama Desert in Chile (Böhlke and others, 2009). This fertilizer was used extensively until the mid-1900s and is still used on some crops, particularly on organic farms (Dasgupta and others, 2006; Böhlke and others, 2009). Because perchlorate is present in precipitation, perchlorate salts can accumulate in the unsaturated zones of soils and aquifer systems, particularly in arid and semiarid environments (Rao and others, 2007; Fram and Belitz, 2011). Agricultural irrigation can then remobilize those salts and transport them into the groundwater system (Fram and Belitz, 2011). Analysis of perchlorate isotopes could potentially aid in the identification of the sources of perchlorate, but that was beyond the scope of this report.

\section{Comparison of Shallow and Public- Supply Aquifer Systems}

In this section, we compare study-unit characteristics and results of groundwater-quality samples collected by the GAMA-PBP in the North San Francisco Bay Public-Supply Aquifer study unit (NSF-PA; Kulongoski and others, 2006, 2010) and the NSF-SA presented in this report and in Bennett and Fram (2014). The NSF-PA and NSF-SA study units largely coincide areally; however, they represent different parts of the aquifer system vertically. The NSF-PA examined deeper groundwater primarily used for public supply, whereas the NSF-SA examined relatively shallow groundwater primarily used for domestic supply. The purpose of the comparison is to identify differences in the quality of groundwater between the study units. Sites sampled in the NSF-PA were randomly selected from a list of wells in the SWRCB-DDW publicsupply well database and were considered to be representative of the public-supply aquifer system, or that part of the aquifer system most often used for public supply.

\section{Comparison of Study-Unit Characteristics}

The NSF-PA covers approximately $2,500 \mathrm{~km}^{2}$, whereas the NSF-SA covers more than $4,500 \mathrm{~km}^{2}$ (fig. 18). Although smaller, the sample density was greater in the NSF-PA than in the NSF-SA. For example, grid cells in each of the study areas in the NSF-PA (Valleys and Plains, Volcanic Highlands, and Wilson Grove Formation Highlands) were designed to achieve an approximate sample density of one site per $25 \mathrm{~km}^{2}$, whereas in the NSF-SA, the grid-cell sizes yielded densities of one site per $30 \mathrm{~km}^{2}$ in the Valleys and Plains study area and one site per $60 \mathrm{~km}^{2}$ in the Highlands study area. The difference in sample density does not affect the ability to make comparisons between the study units. Areal proportions were calculated in the same manner in both study units, and proportions of the aquifer that have high concentrations of individual constituents or classes of constituents can be directly compared in this manner.

In the NSF-PA, there are three study areas - the Wilson Grove Formation Highlands, the Volcanic Highlands, and the Valleys and Plains - whereas in the NSF-SA, there are only two - the Highlands and the Valleys and Plains. For simplification, throughout the remainder of the report, the Wilson Grove Formation Highlands and the Volcanic Highlands are collectively discussed as the NSF-PA Highlands study area. The Valleys and Plains study area in the NSF-PA is nearly identical in extent to the NSF-SA Valleys and Plains study area, except the NSF-PA Valleys and Plains study area extends farther to the southeast (fig. 18). When comparing the NSF-PA and NSF-SA Highlands areas, the difference in size is notable. The NSF-SA Highlands area surrounds nearly the entire Valleys and Plains study area, whereas the NSF-PA Highlands study area only flanks the central and southern parts of the Valleys and Plains study area (fig. 18). Because of this contrast, 19 of the 40 sites sampled for the NSF-SA, but outside of the boundaries defined by the NSF-PA Highlands study area, were not included in the comparison of these two study areas. Ultimately, all 30 NSF-SA Valleys and Plains study areas sites and 21 NSF-SA Highlands study area sites were included in the comparison. Sites not included are identified in appendix table 1-1. Aquifer-scale proportions were recalculated accordingly for the NSF-SA on the basis of this revised dataset.

General study-unit characteristics, specifically, well construction, land use, groundwater age, general chemical composition, and geochemical conditions, were compared to identify differences that could affect interpretations of water-quality results. All comparisons were made at the studyunit scale using data from grid sites. Additionally, for well construction, land use, and general chemical composition, comparisons were also made at the study-area scale.

\section{Well-Construction Comparison}

Well depths in the NSF-PA ranged from 18 to $263 \mathrm{~m}$ below land surface with a median of $97 \mathrm{~m}$. Sites included in the comparison from the NSF-SA had well depths that ranged from 8 to $230 \mathrm{~m}$ with a median of $58 \mathrm{~m}$ below land surface. Comparing well depths from the NSF-PA and NSF-SA at the study-unit scale using the Wilcoxon rank-sum test indicated that wells in the NSF-PA were significantly deeper than wells in the NSF-SA $(p=0.001)$. For the individual study areas, results of Wilcoxon rank-sum tests showed that NSF-PA wells in the Valleys and Plains study area were significantly deeper than the NSF-SA wells ( $p=0.011$; fig. 19). 


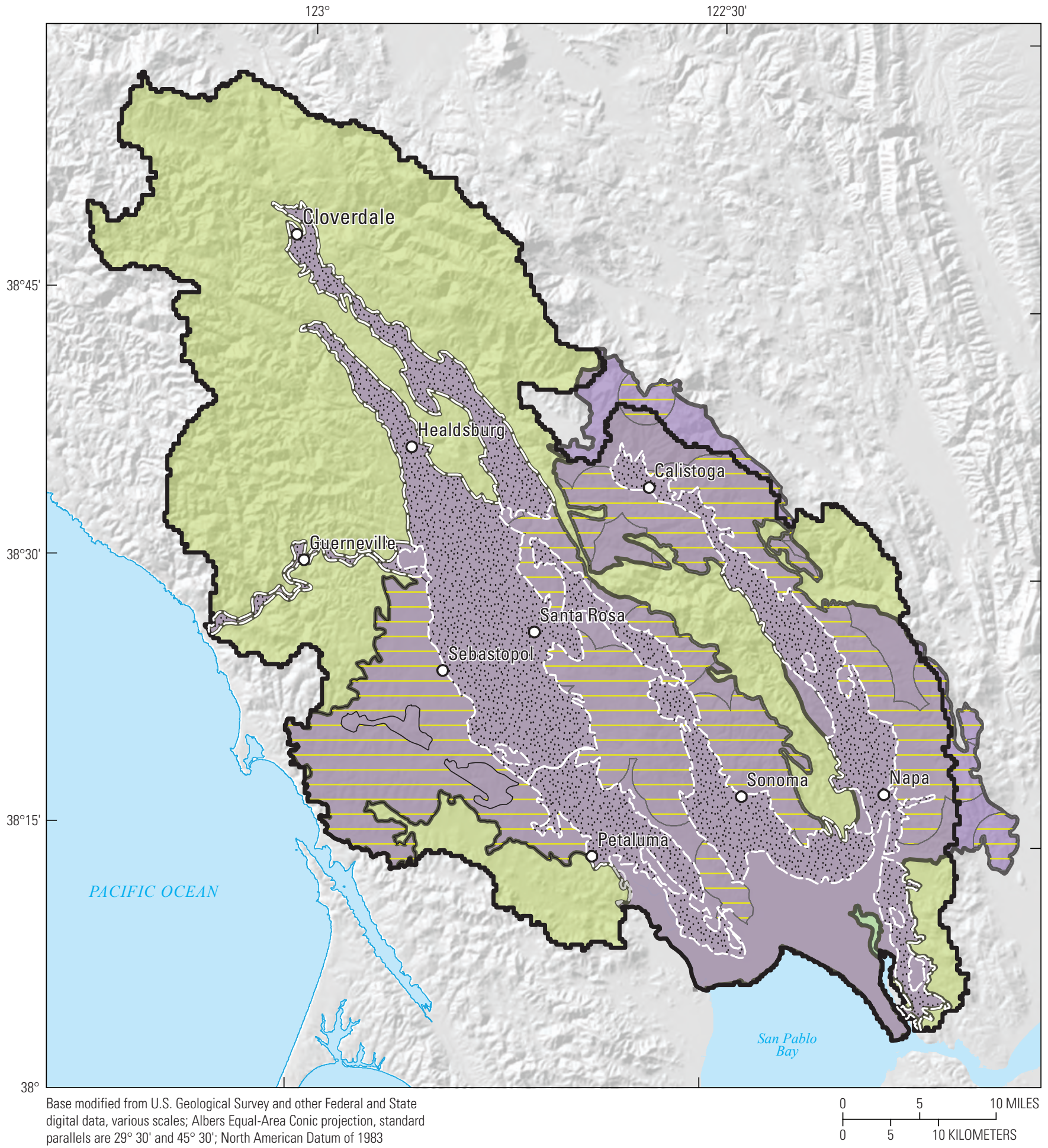

EXPLANATION

North San Francisco Bay studies

\begin{tabular}{|l|l|l}
\hline Public-Supply Aquifer study unit boundary & Public-Supply Aquifer Highlands study area \\
\hline Shallow Aquifer study unit boundary & Shallow Aquifer Valleys and Plains study area
\end{tabular}

Figure 18. Study area extents of the Public-Supply Aquifer study unit (NSF-PA) and Shallow Aquifer study unit (NSF-SA), North San Francisco Bay, California Groundwater Ambient Monitoring and Assessment (GAMA) Program Priority Basin Project. 


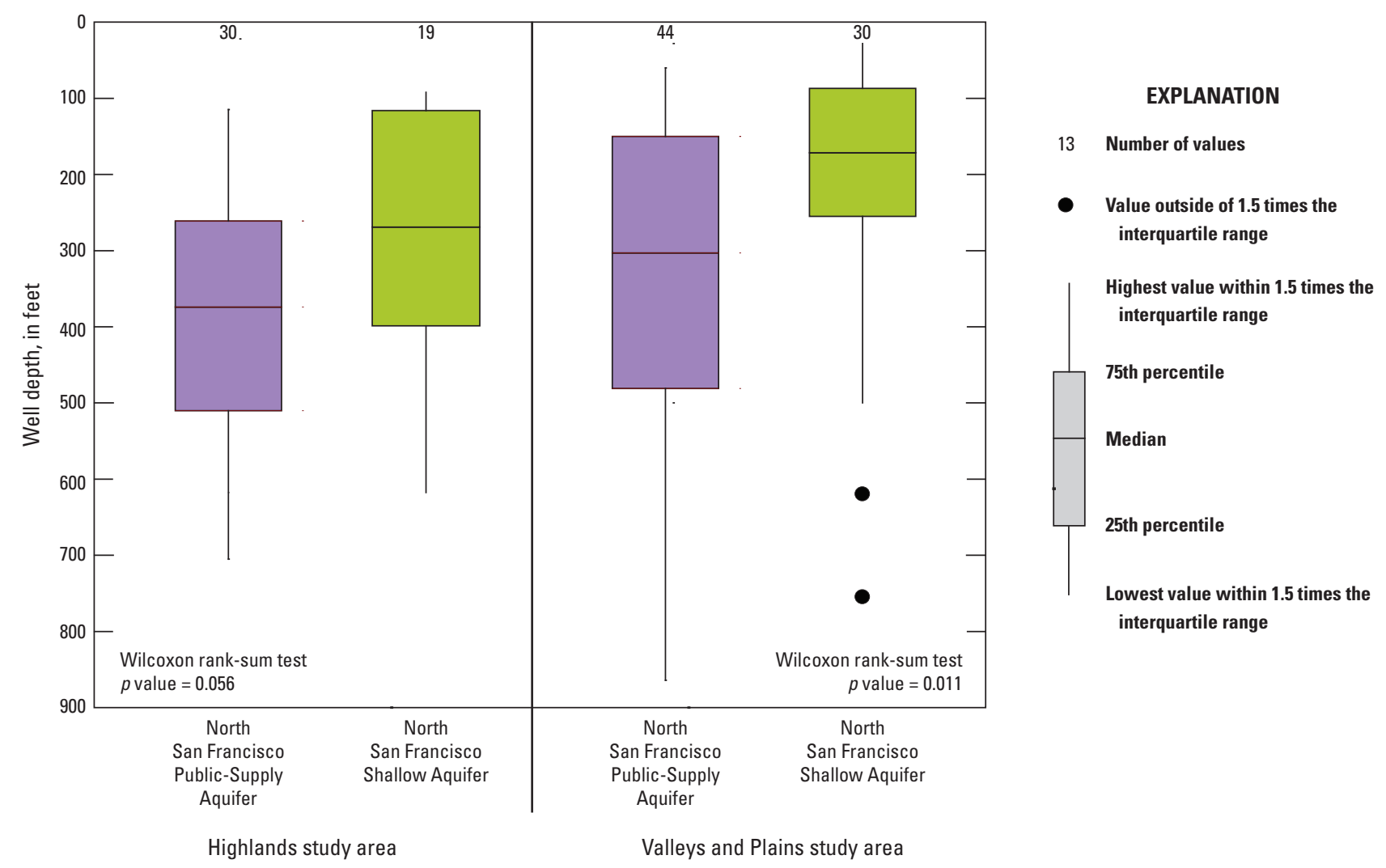

Figure 19. Well depths by study area for North San Francisco Bay Public-Supply Aquifer study unit (NSF-PA) and Shallow Aquifer study unit (NSF-SA), California Groundwater Ambient Monitoring and Assessment (GAMA) Program Priority Basin Project.

In the Highlands study areas, the median depths of wells in the NSF-PA were deeper than those in the NSF-SA; however, the difference was not statistically significant ( $p=0.056$; fig. 19). This is likely because in areas outside of groundwater basins, the fractured-rock aquifers are most productive at depths where fractures in the local rock are saturated with water, and the density of fractures typically decreases with depth (Freeze and Cherry, 1979; Page and others, 1984; Borchers, 1996; Ingebritsen and Sanford, 1998). In fractured hard-rock settings, therefore, the viable production wells tend to be constrained by these fracture zones, potentially resulting in less stratification of well depths according to the well's primary use.

\section{Land-Use Comparison}

Land-use data from 2011 (National Land Cover Database 2011) were applied to characterize sites from both study units for comparison. General land-use characteristics within a 500-m radius surrounding each sampled site were averaged for each of the study units and found to be similar (fig. 20). Wilcoxon rank-sum test comparisons between corresponding study areas of each study unit showed no significant difference between the land-use categories. This indicated that the wells selected for the NSF-PA and NSF-SA had similar distributions with respect to land use.

\section{Groundwater Age Comparison}

Multiple groundwater age tracers were collected in both study units; however, not all tracers were collected at all grid wells in each study unit. The only groundwater age tracer collected at a sufficient number of sites in both study units to make meaningful comparisons was tritium. A simplified age-classification system was constructed using tritium concentrations to assign a groundwater sample to a pre-modern, mixed, or modern age class. Samples with tritium activity less than $0.2 \mathrm{TU}$ were classified as pre-modern; greater than or equal to $0.2 \mathrm{TU}$, but less than $1 \mathrm{TU}$ were classified as mixed; and greater than or equal to $1 \mathrm{TU}$ were classified as modern.

The median concentration of tritium in samples collected in the NSF-PA was less than 1 tritium unit (TU), which was significantly less than the median concentration observed in the NSF-SA (greater than 3 tritium units; fig. 21A). As expected from the tritium concentrations, the NSF-SA had a greater proportion of modern groundwater samples and a lesser proportion of pre-modern groundwater samples than the NSF-PA (fig. 21B). 

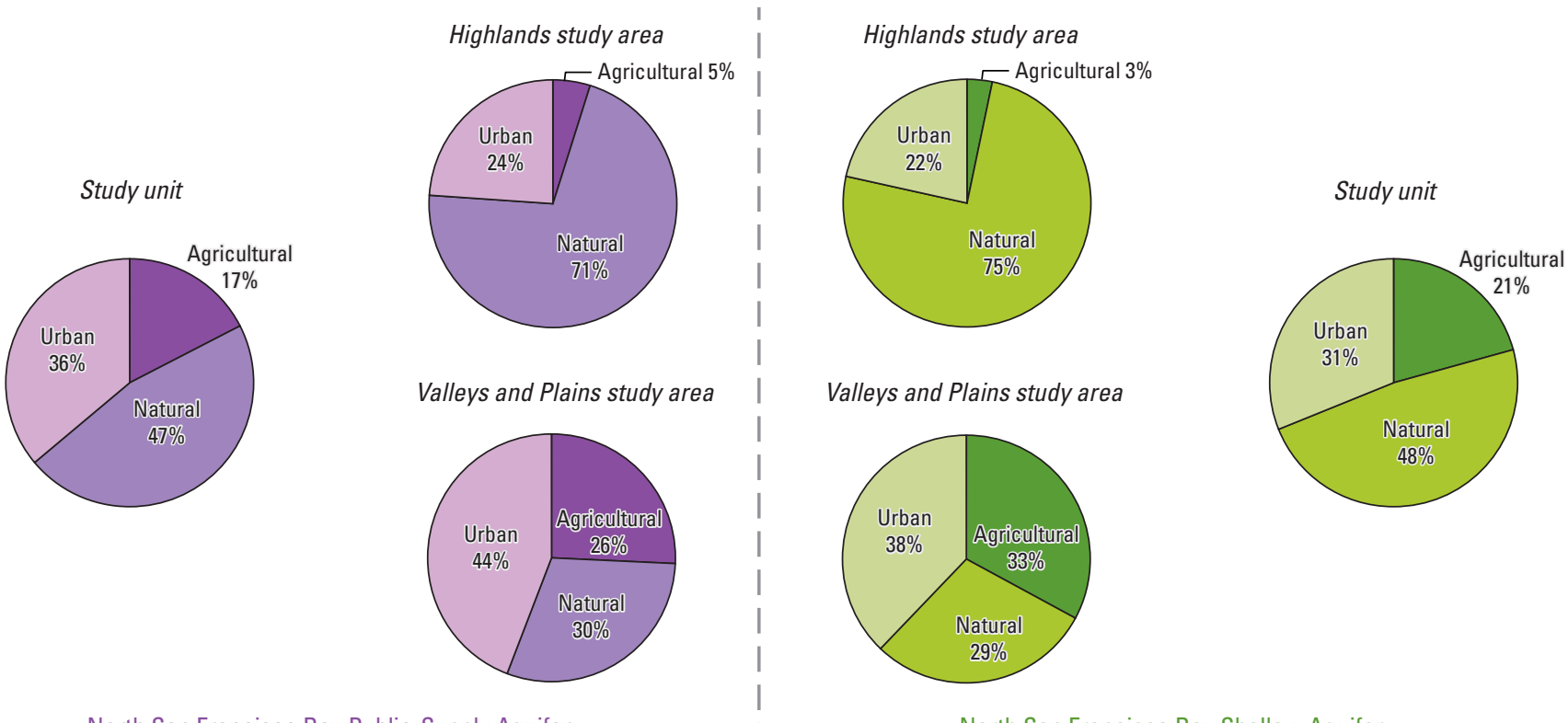

North San Francisco Bay Public-Supply Aquifer

Figure 20. The 2011 land use by study area, as the average percentage by land-use category of circular area within 500 meters of sampled sites, for North San Francisco Bay Public-Supply Aquifer study unit (NSF-PA) and Shallow Aquifer study unit (NSF-SA), California Groundwater Ambient Monitoring and Assessment (GAMA) Program Priority Basin Project.

A

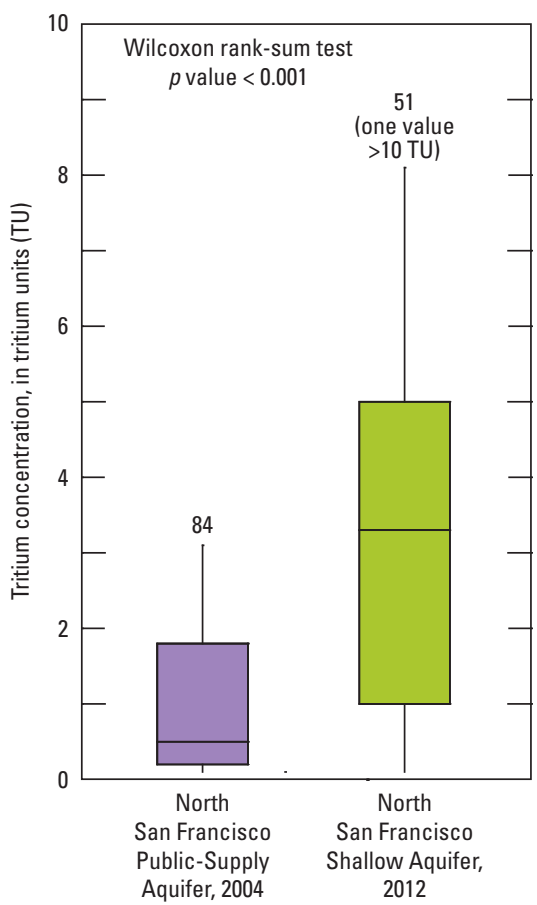

B

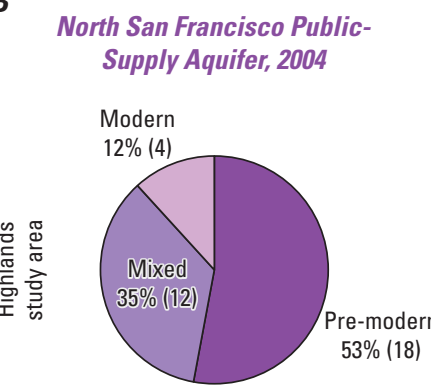

North San Francisco Shallow Aquifer, 2012

EXPLANATION

51 Number of values

Highest value within
1.5 times the

interquantile range

75th percentile

Median
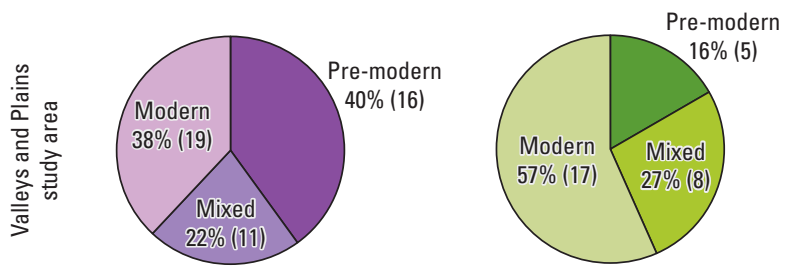

(The number in parentheses is the number of samples classified as modern, mixed, or pre-modern in each study area)

Figure 21. Groundwater age-dating sampling results in the Highlands and Valleys and Plains study areas of the North San Francisco Bay Public-Supply Aquifer study unit (NSF-PA), sampled 2004, and the Shallow Aquifer study unit (NSF-SA), sampled 2012, California Groundwater Ambient Monitoring and Assessment (GAMA) Program Priority Basin Project: A, box plots of frequency distribution of tritium concentrations, and $B$, percentages of samples classified as modern, mixed, or pre-modern age. [\%, percent] 
Groundwater age classifications of samples from the Valleys and Plains study areas of the NSF-PA and NSF-SA were significantly different, whereas groundwater age classifications of samples from the Highlands study areas of the NSF-PA and NSF-SA were not significantly different. The Valleys and Plains of the NSF-SA had a smaller proportion of groundwater samples classified as pre-modern, as opposed to mixed or modern, than the Valleys and Plains of the NSF-PA (fig. $21 B$, contingency table test $p=0.03$ ). Groundwater ages generally increase with well depth, and wells in the Valleys and Plains of the NSF-PA were significantly deeper than wells in the NSF-SA (fig. 19). Although wells in the Highlands of the NSF-PA were deeper than Highlands's wells in the NSF-SA, the difference was not statistically significant (fig. 19).

Comparing the Valleys and Plains study areas with Highlands study areas, groundwater age classifications were significantly different from each other both in the NSF-PA and the NSF-SA. For the NSF-SA, the Valleys and Plains study area had a greater proportion of modern and smaller proportion of pre-modern groundwater than the Highlands study area (fig. 21B). For the NSF-PA, the Valleys and Plains study area had a greater proportion of modern groundwater than the Highlands study area (fig. 21B). The significantly greater proportion of modern water in the Valleys and Plains study area than in the Highlands study area for both study units likely reflects differences in well depths and in recharge properties between the Valleys and Plains study areas. Wells in the Valleys and Plains were generally shallower than Highlands' wells in both study units, but the difference was not significant (fig. 19). Recharge to the alluvial aquifers of the Valleys and Plains study area is likely to be more rapid than recharge to the fractured-rock systems of the Highlands study area, owing to the lower permeability and steeper slopes of the Highlands study area (Woolfenden and Nishikawa, 2014). This allows modern groundwater to penetrate more deeply in the Valleys and Plains aquifer systems than in the Highlands aquifer systems.

\section{General Chemical Composition Comparison}

Trilinear diagrams show the compositional proportions of cations and anions, which allow for the comparison and classification of water samples (Hem, 1985). Groundwater samples from the NSF-PA and NSF-SA were plotted and compared to see if there were differences in either the variety or frequency of water types between the study units or study areas (fig. 22). A common convention used when describing water type using the trilinear diagram is to base the description on the dominant cation and anion species. In this report, a cation or anion representing more than 60 percent of the total milliequivalents of cations or anions is considered the dominant ion. Where no one cation or anion exceeds 60 percent, the sample is described as mixed.

Comparing the NSF-PA and NSF-SA using the trilinear diagram shows that a similar range of water types was sampled in both study units (fig. 22). The predominant water type among a majority of the samples from both study units was mixed-bicarbonate, followed by mixed-cation and mixed-anion type waters. Less frequently encountered, but not uncommon, was the sodium-bicarbonate water type, which was found more often in NSF-SA samples. Two sites in the NSF-SA Highlands study area exhibited a magnesium-sulfate water type that was not observed in the NSF-PA (fig. 22).

\section{Geochemical Condition Comparison}

Geochemical conditions for samples collected in the two studies were difficult to compare at the study-unit scale, because many of the samples in the NSF-PA were missing the necessary constituent information used to identify a sample's redox state. Only 19 of the 83 USGS grid well samples in the NSF-PA had data for DO, nitrate, iron, and manganese concentrations (Kulongoski and others, 2006). The median value of $\mathrm{pH}$ tended to be closer to neutral (7.0) in the NSF-SA than in the NSF-PA, where it was closer to 7.5 (fig. 23). Values of $\mathrm{pH}$ generally rise as longer groundwater residence time increases contact with aquifer materials as a result of weathering reactions with silicate and carbonate minerals, if present (Stumm and Morgan, 1996).

\section{Comparison of Water Quality}

Constituents selected for additional evaluation were the focus of the groundwater-quality comparison between the study units. Among inorganic constituents selected for additional evaluation in both study units were the trace elements, arsenic, boron, and manganese; two inorganic constituents with aesthetic-based benchmarks, iron and TDS; and the nutrient nitrate. The organic constituent chloroform had a detection frequency greater than 10 percent in both study units. Because of results from the NSF-SA, one specialinterest constituent, perchlorate, and one pesticide, dieldrin, were also selected for additional evaluation. Although boron was selected for additional evaluation in both study units, sites where it was detected at high and moderate RCs in the NSF-SA were in the group of sites removed from study-unit comparison because they were outside of the boundaries of the NSF-PA. Fluoride also is not discussed in this section of the report for the same reason that boron is not given additional comparison. 


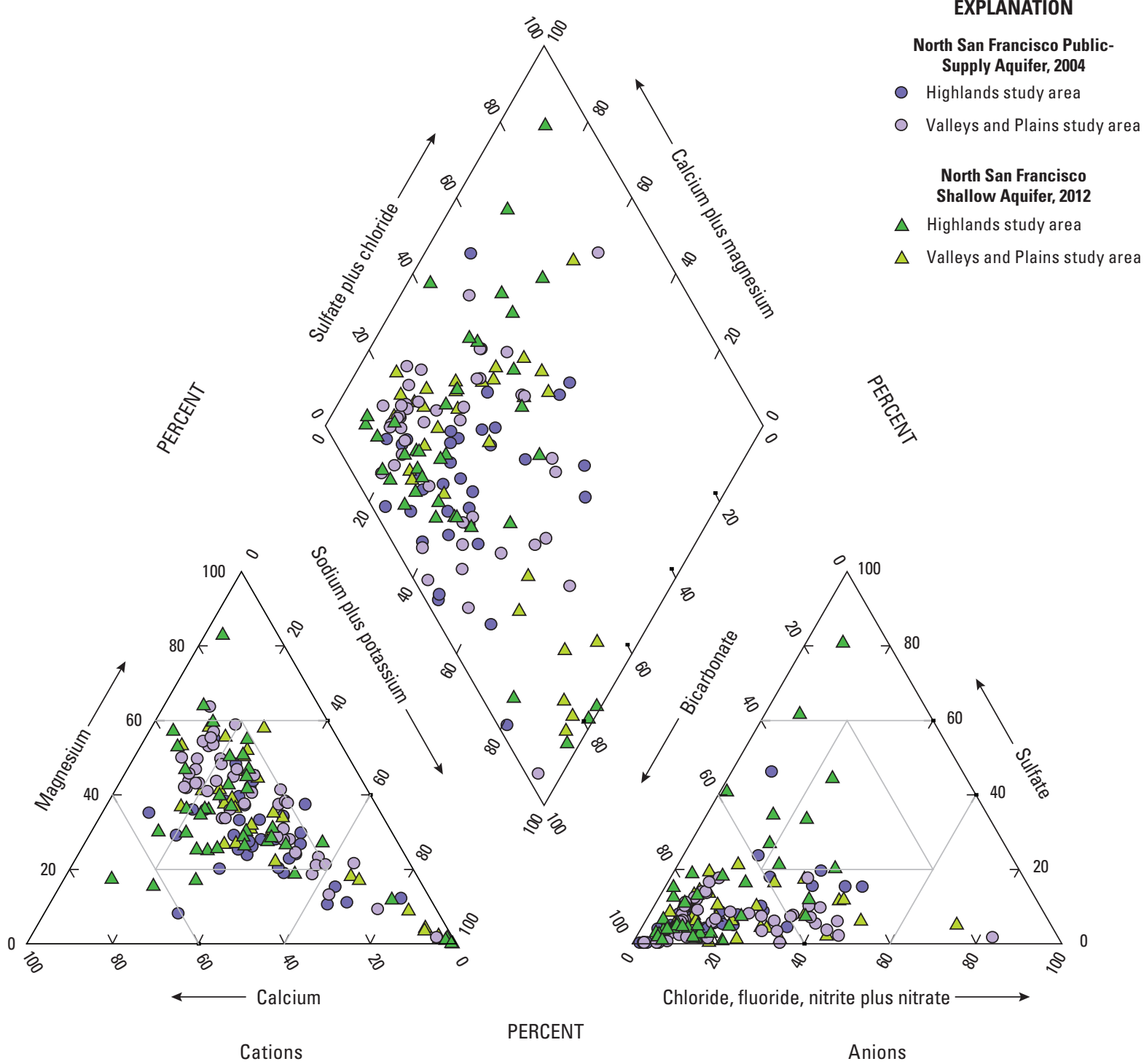

Figure 22. Chemical ionic composition of groundwater in samples from sites in the North San Francisco Bay Public-Supply Aquifer study unit (NSF-PA), 2004, and Shallow Aquifer study unit (NSF-SA), 2012, California Groundwater Ambient Monitoring and Assessment (GAMA) Program Priority Basin Project. 


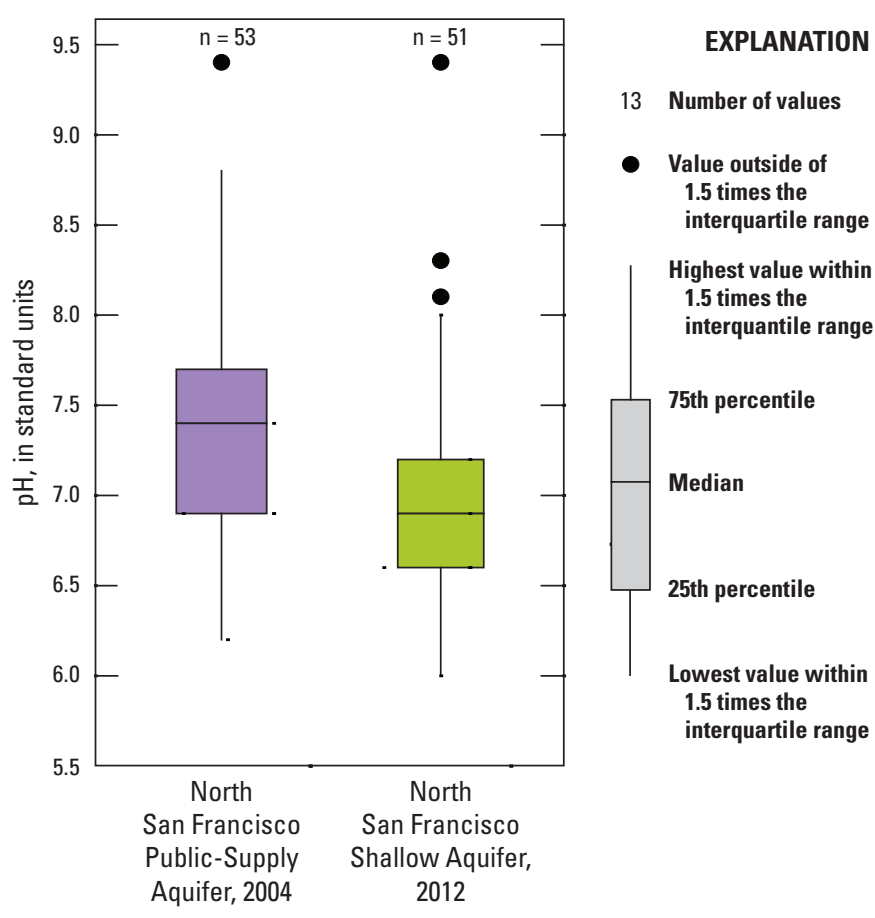

Figure 23. $\mathrm{pH}$ values in samples from the North San Francisco Bay Public-Supply Aquifer study unit (NSF-PA), 2004, and Shallow Aquifer study unit (NSF-SA), 2012, California Groundwater Ambient Monitoring and Assessment (GAMA) Program Priority Basin Project.

\section{Inorganic Constituents}

Differences in the proportions of low, moderate, and high RCs are presented by inorganic constituent class or by individual inorganic constituent with and without health-based benchmarks (HBBs; figs. 24-27). Differences in proportions of RCs at the scale of the study unit and the study areas are presented. When comparing the NSF-PA and NSF-SA at the study-unit scale, no significant differences were observed. A few significant differences were observed when comparing the study areas of the two study units independently. The NSF-SA Valleys and Plains study area had significantly larger proportions of samples with high RCs of any inorganic constituent with HBBs (fig. 24, contingency table test $p=0.01$ ), trace elements (fig. 25, contingency table test $p=0.05$ ), nitrate (fig. 26A, contingency table test $p=0.09$ ), and manganese (fig. $26 C$, contingency table test $p=0.04$ ) than the NSF-PA Valleys and Plains study area.

\section{Organic and Special-Interest Constituents}

Organic constituents were present in similar proportions in the NSF-SA and NSF-PA. Organic constituents were present at concentrations greater than reporting limits in about one-third of the groundwater resources in the NSF-SA and
NSF-PA Valleys and Plains study areas and in 21 percent of the groundwater resources in the NSF-SA and NSF-PA Highlands study areas (fig. 28). The areal proportions of the aquifer in each RC category of organic constituents did not differ significantly between the Highlands study area and Valleys and Plains study area for either the NSF-SA or the NSF-PA (contingency table test $p$ greater than 0.1 ) study units. Organic constituents were present at high or moderate RCs in 3 percent of the NSF-SA Valleys and Plains and NSF-PA Highlands study areas (fig. 28). The small proportion of samples in which organic constituents were present at high or moderate concentrations was not significantly different among the four study areas (contingency table tests $p$ greater than 0.1).

The organic constituent classes present in greater than 10 percent of any of the study areas were trihalomethanes and herbicides (fig. 29). There were no significant differences in proportions with detections of these organic constituent classes between the NSF-SA and NSF-PA Highlands study areas nor between the NSF-SA and NSF-PA Valleys and Plains study areas.

The proportion of wells with detections of herbicides was significantly greater in the Valleys and Plains study area than in the Highlands study area in the NSF-PA (contingency table test $p$ less than 0.01; fig. 29). Simazine was the most frequently detected herbicide in the Valleys and Plains study areas of both study units. It was unexpected that herbicide detection frequency in the Valleys and Plains study areas of the NSF-SA and NSF-PA were not significantly different. The deeper wells, combined with generally older groundwater ages of samples from NSF-PA wells, indicated that NSF-PA samples would be less likely to contain constituents from anthropogenic sources.

The VOC classified as naturally present is carbon disulfide. It is inferred to be natural in origin because of its detection pattern. Fifteen samples in the two study units had detections of carbon disulfide at concentrations ranging from 0.03 to $3.6 \mu \mathrm{g} / \mathrm{L}$. There were $\mathrm{DO}$ or iron and manganese data available for 12 of the 15 samples, and all 12 samples were classified as iron- and manganese-reducing, manganese-reducing, or suboxic, indicating reduced redox conditions. Carbon disulfide can be formed naturally under sulfate-reducing conditions (Chin and Davis, 1993; Devai and DeLaune, 1995). In 73 percent of the 15 samples, carbon disulfide was the only organic constituent detected, and in the remaining 27 percent, it was accompanied by only one other organic constituent. If the carbon disulfide had been from an industrial source, it would be less likely for it to be detected by itself, rather, detection of other solvents or industrial VOCs would be more likely. The Valleys and Plains study areas of both study units had similar detection frequencies of carbon disulfide, and the differences between the Highlands study areas were not significant (fig. 29). This was expected given that the conditions under which carbon disulfide can be produced naturally (anoxic conditions) existed in both study areas of the NSF-PA and NSF-SA. 


\section{Any inorganic constituent with a health-based benchmark}

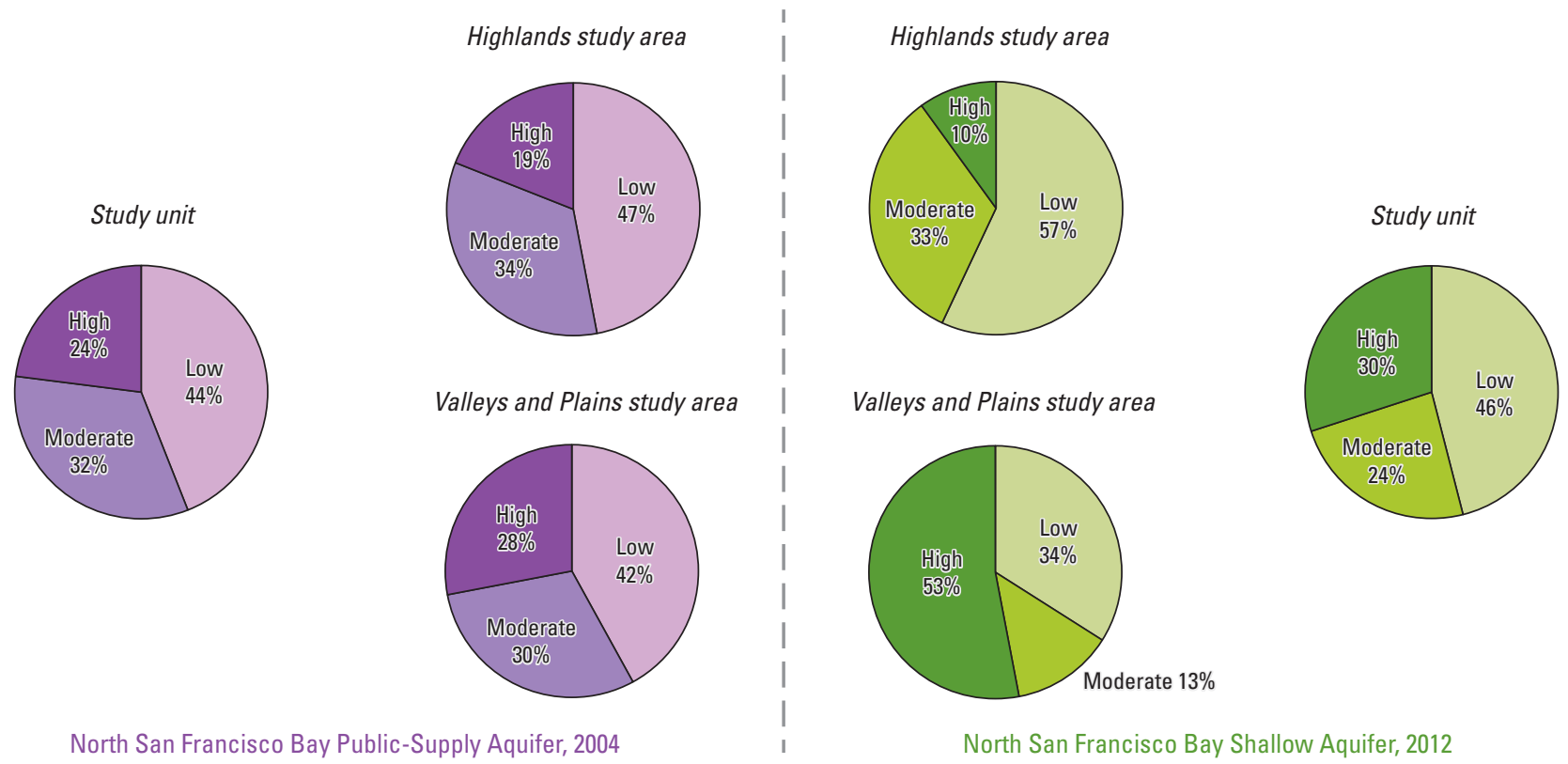

Figure 24. Summarizing by study unit and study area the proportions of samples with high, moderate, and low relative concentrations for any inorganic constituent with health-based benchmarks (HBBs) as a group, North San Francisco Bay Public-Supply Aquifer study unit (NSF-PA), sampled in 2004, and Shallow Aquifer study unit (NSF-SA), sampled in 2012, California Groundwater Ambient Monitoring and Assessment (GAMA) Program Priority Basin Project. [\%, percent]

Trace elements with health-based benchmarks

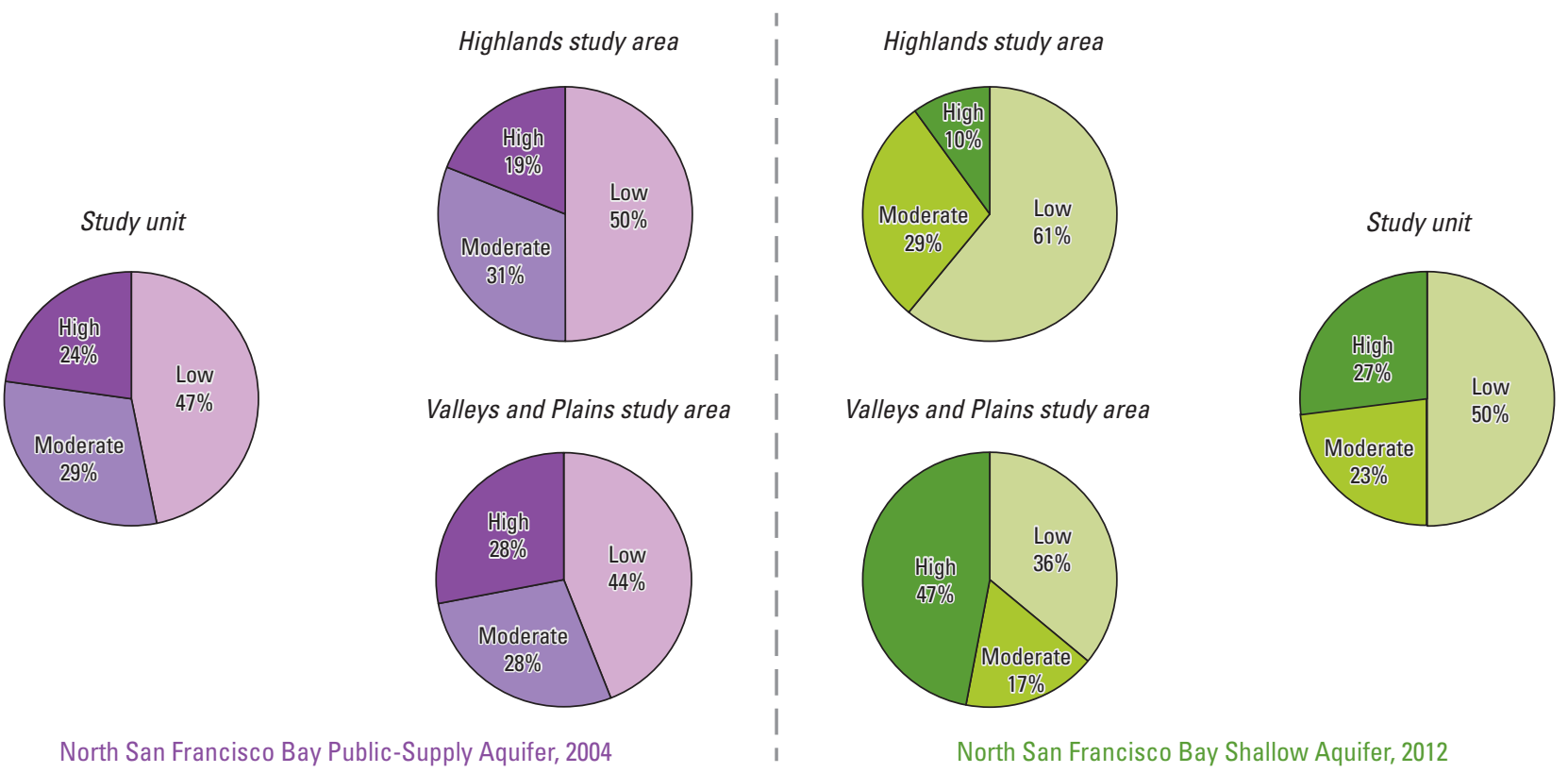

Figure 25. Summarizing by study unit and study area the proportions of samples with high, moderate, and low relative concentrations for trace elements with health-based benchmarks (HBBs) as a group, North San Francisco Bay Public-Supply Aquifer study unit (NSF-PA), sampled in 2004, and Shallow Aquifer study unit (NSF-SA), sampled in 2012, California Groundwater Ambient Monitoring and Assessment (GAMA) Program Priority Basin Project. [\%, percent] 
North San Francisco Bay Public-Supply Aquifer, 2004

A

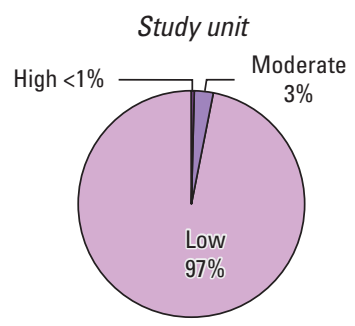

Study unit

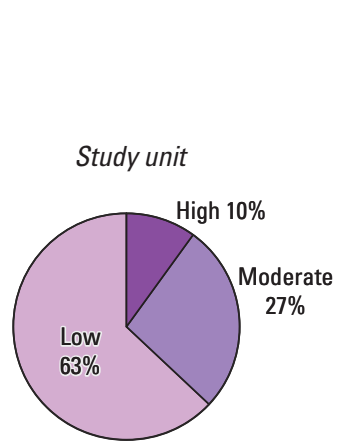

$\boldsymbol{B}$

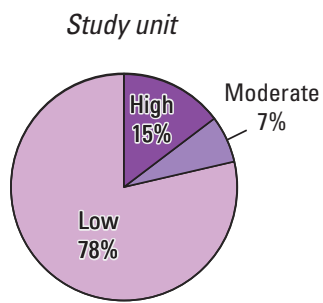

C

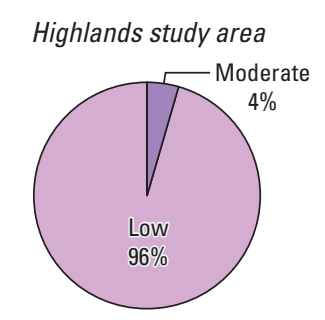

Valleys and Plains study area High $<1 \% \square \square$ Moderate

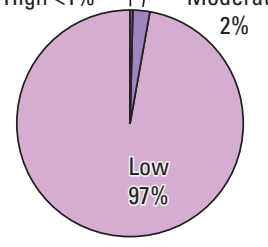

North San Francisco Bay Shallow Aquifer، 2012

Nitrate

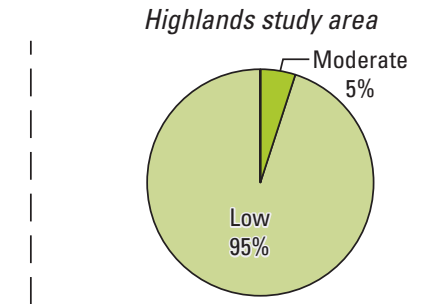

Valleys and Plains study area
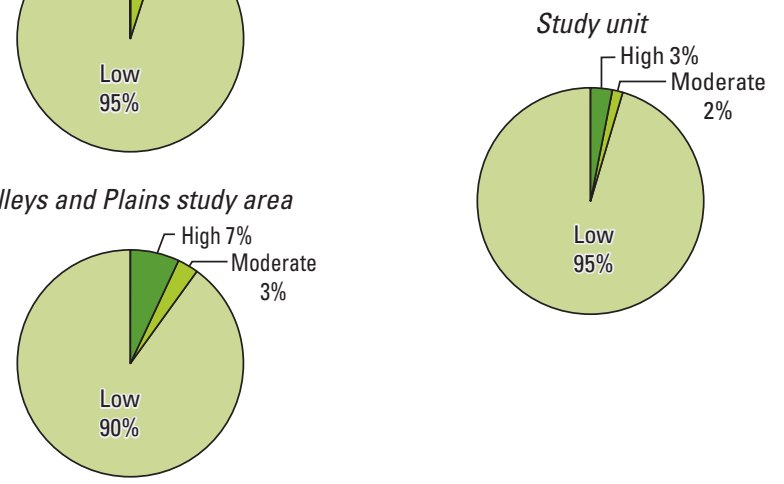

Highlands study area

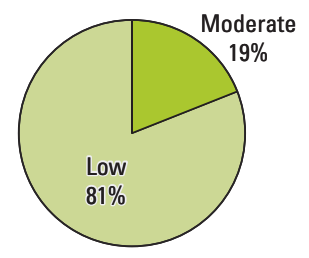

Valleys and Plains study area

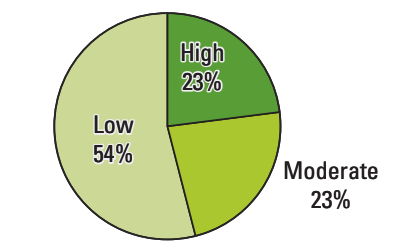

Study unit

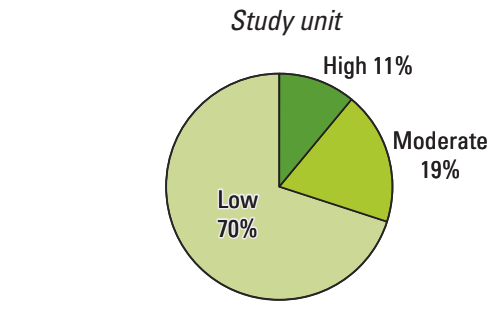

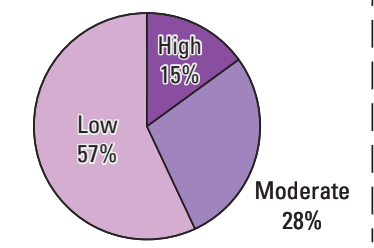

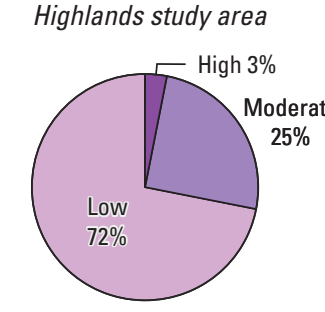

Valleys and Plains study area
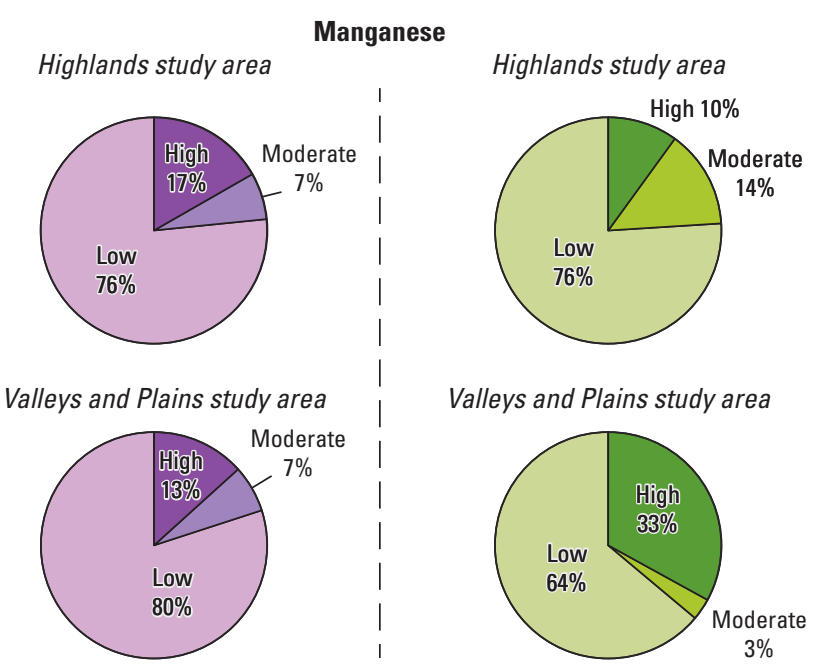

Valleys and Plains study area
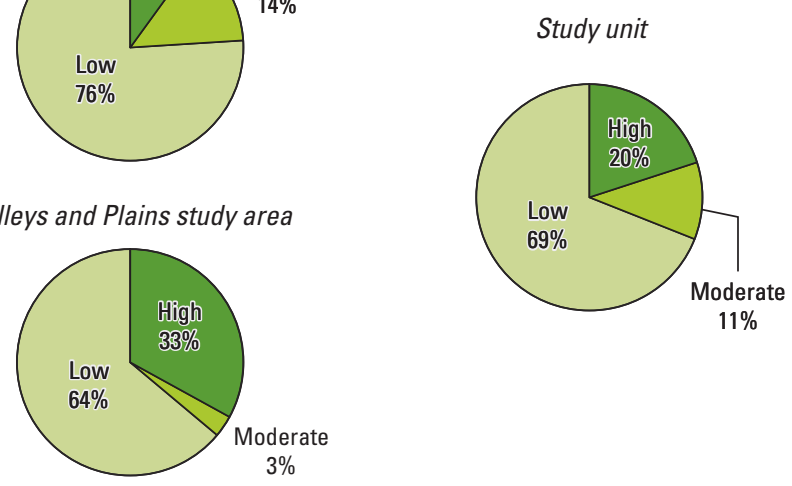

Figure 26. Summarizing by study unit and study area the proportions of samples with high, moderate, and low relative concentrations, North San Francisco Bay Public-Supply Aquifer study unit (NSF-PA), sampled in 2004, and Shallow Aquifer study unit (NSF-SA), sampled in 2012, California Groundwater Ambient Monitoring and Assessment (GAMA) Program Priority Basin Project for $A$, nitrate; $B$, arsenic; and $C$, manganese. [\%, percent] 
Highlands study area
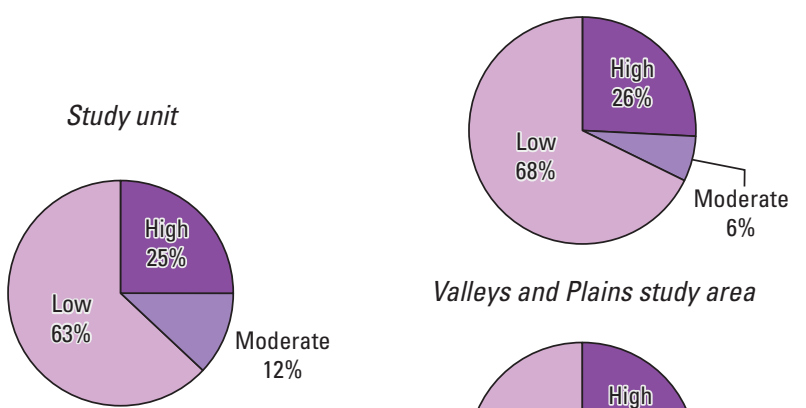

Valleys and Plains study area

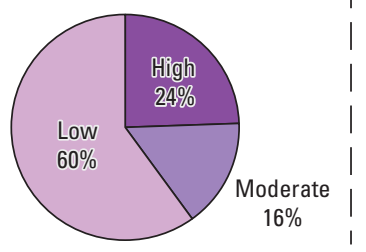

Valleys and Plains study area

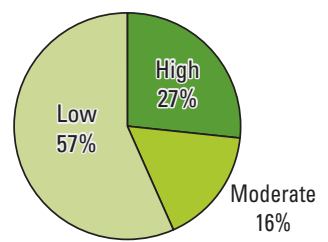

Highlands study area

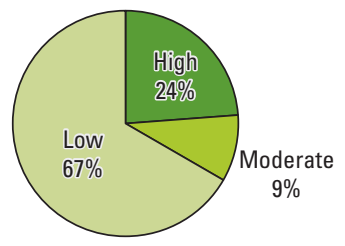

Study unit

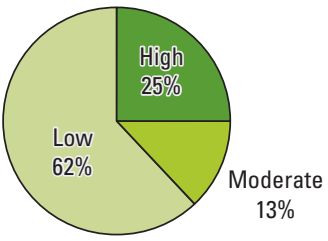

B

Study unit

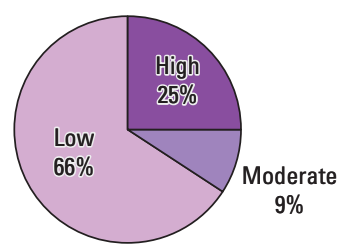

Study unit

High $1 \% \neg \quad$ Moderate $7 \%$

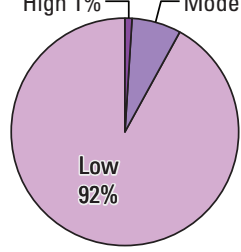

C
Trace elements (non-health-based benchmark)

Highlands study area

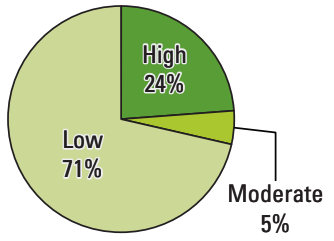

Valleys and Plains study area
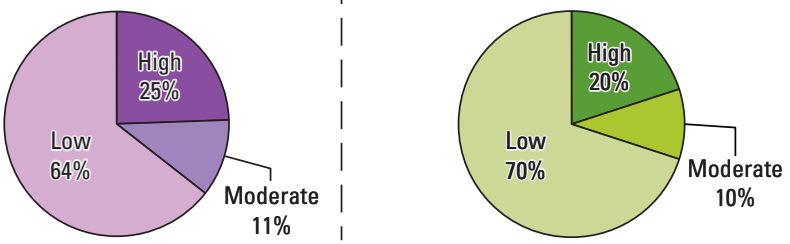

$11 \%$
Study unit

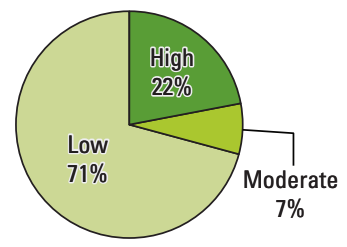

Valleys and Plains study area

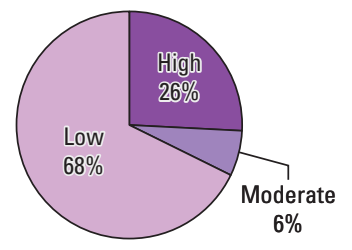

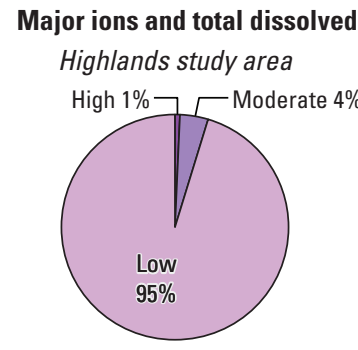

Valleys and Plains study area

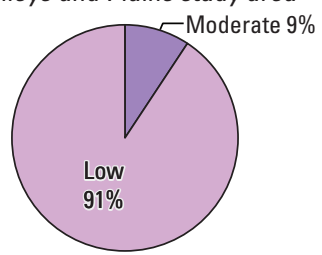

(non-health-based benchmark)

Highlands study area

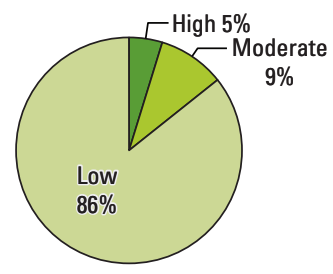

Valleys and Plains study area

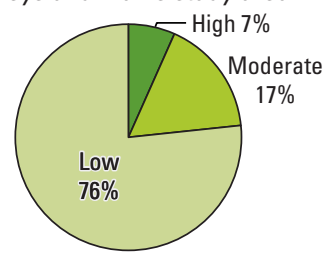

Study unit

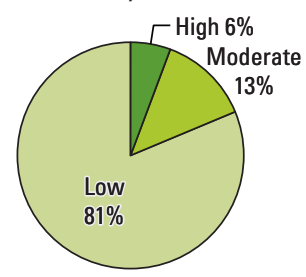

Figure 27. Summarizing by study unit and study area the proportions of samples with high, moderate, and low relative concentrations of inorganic constituents with aesthetic-based secondary maximum contaminant levels (SMCLs) by constituent class, in the North San Francisco Bay Public-Supply Aquifer study unit (NSF-PA) and Shallow Aquifer study unit (NSF-SA) and their study areas, 2012, California Groundwater Ambient Monitoring and Assessment (GAMA) Program Priority Basin Project, for $A$, any inorganic constituent; $B$, trace elements; and $C$, major ions and total dissolved solids. [\%, percent] 


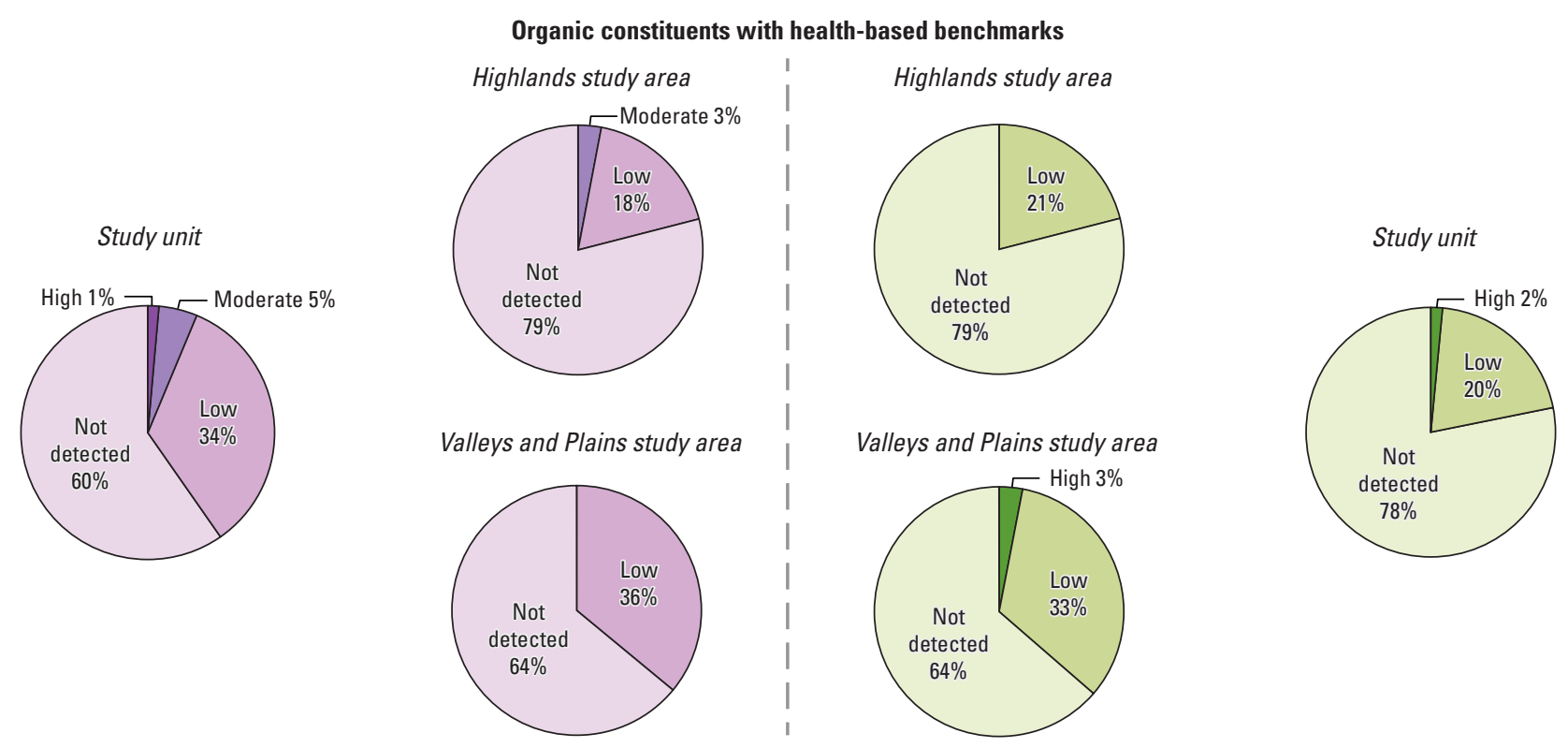

Figure 28. Summarizing by study unit and study area the proportions of samples with high, moderate, and low relative concentrations and non-detections for organic constituents with health-based benchmarks as a group, North San Francisco Bay Public-Supply Aquifer study unit (NSF-PA), sampled in 2004, and Shallow Aquifer study unit (NSF-SA), sampled in 2012, California Groundwater Ambient Monitoring and Assessment (GAMA) Program Priority Basin Project. [\%, percent]

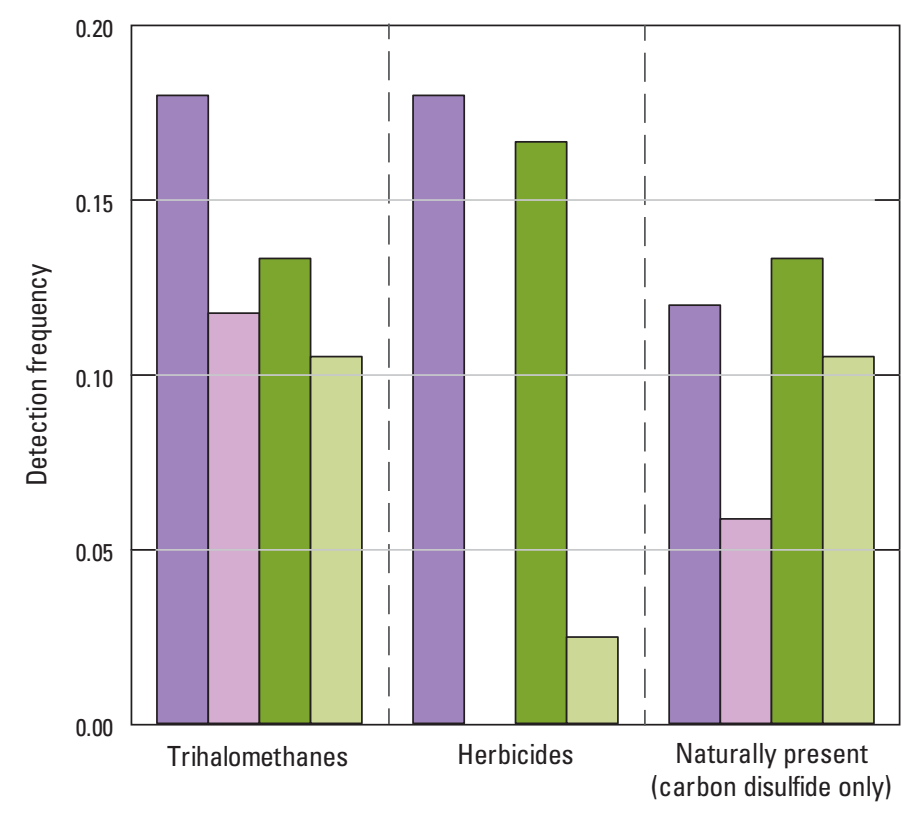

\section{EXPLANATION}

North San Francisco Bay Public-Supply Aquifer, 2004

Valleys and Plains study area

Highlands study area

North San Francisco Bay Shallow Aquifer, 2012

Valleys and Plains study area

Highlands study area

Figure 29. Detection frequency by study area of organic constituent classes in the North San Francisco Bay Public-Supply Aquifer study unit (NSF-PA), sampled 2004, and Shallow Aquifer study unit (NSF-SA), sampled 2012, California Groundwater Ambient Monitoring and Assessment (GAMA) Program Priority Basin Project. (Only organic constituent classes with detection frequency greater than 0.1 in one or more study areas are included.) 
North San Francisco Bay Public-Supply Aquifer, 2004

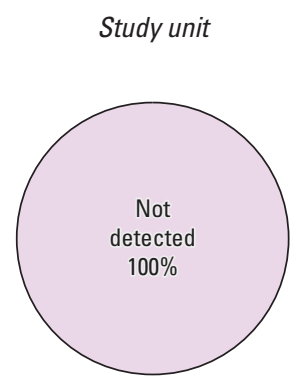

Highlands study area

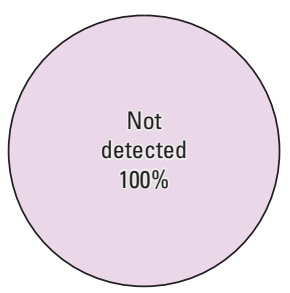

Valleys and Plains study area

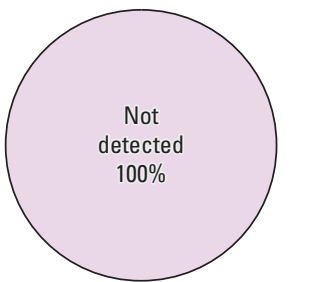

North San Francisco Bay Shallow Aquifer, 2012

Highlands study area

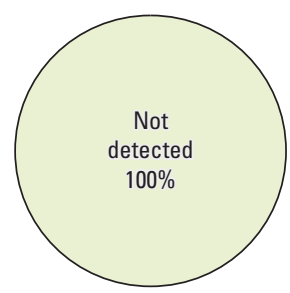

Valleys and Plains study area

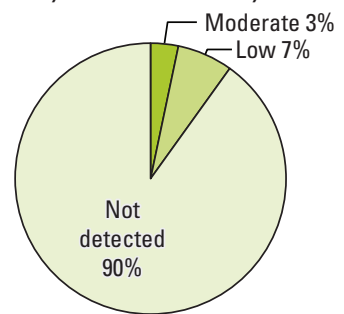

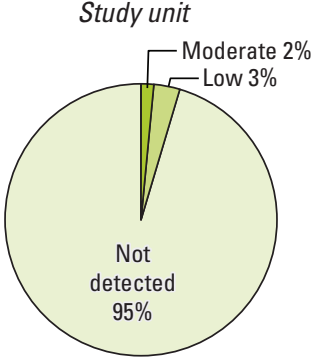

Figure 30. Graphs summarizing by study unit and study area the proportions of samples with moderate and low relative concentrations and non-detections of perchlorate in the North San Francisco Bay Public-Supply Aquifer study unit (NSF-PA), sampled in 2004, and Shallow Aquifer study unit (NSF-SA), sampled in 2012, California Groundwater Ambient Monitoring and Assessment (GAMA) Program Priority Basin Project. [\%, percent]

Perchlorate was analyzed in the studies of the NSF-PA and NSF-SA; however, laboratory reporting levels were different. The NSF-SA results were re-censored to the NSF-PA reporting level so the data could be directly compared. The NSF-PA and NSF-SA Highlands study areas had no detections and, hence, did not have significantly different detection frequencies (contingency table test $p=0.18$ ); whereas, the detection frequency in the Valleys and Plains of the NSF-SA was significantly greater than in Valleys and Plains of the NSF-PA (contingency table test $p=0.02$; fig. 30). This difference could be related to observations made about perchlorate in the assessment of the NSF-SA described earlier in this report. Two mechanisms were hypothesized by which agricultural activities can contribute perchlorate to groundwater; these are the addition of perchlorate found in some fertilizers and the remobilization of endemic perchlorate salts by irrigation. The application of imported fertilizers containing a minor component of perchlorate until the mid-1900s could have left residue in the unsaturated zone (Dasgupta and others, 2006; Böhlke and others, 2009). These residues, along with natural perchlorate salts that can accumulate in the unsaturated zone (Rao and others, 2007; Fram and Belitz, 2011), could be remobilized by percolating irrigation water and account for detections of perchlorate in the NSF-SA Valleys and Plains study area. The absence of perchlorate detections in the NSF-PA Valleys and Plains study area could be related to the greater well depths or the removal of perchlorate through a redox-related process before it reaches the deeper aquifer system.

\section{Summary}

Groundwater quality in the approximately 4,790-squarekilometer North San Francisco Bay Shallow Aquifer study unit (NSF-SA) was investigated as part of the Priority Basin Project (PBP) of the Groundwater Ambient Monitoring and Assessment (GAMA) Program. The GAMA-PBP provides a spatially unbiased characterization of untreated groundwater quality in the shallow aquifer system. The shallow aquifer was defined using wells with depth intervals shallower, on average, than in the public-supply wells listed in the California State Water Resources Control Board Division of Drinking Water water-quality database.

This report presents a description of the hydrogeologic setting of the NSF-SA, a study-unit assessment of the groundwater quality in the shallow aquifer system of the NSF-SA during 2012, a general identification of natural and anthropogenic factors that could be affecting groundwater quality, and a comparison between the quality of groundwater in the shallow aquifer system and the quality of groundwater resources used for public drinking water. The study-unit assessment was based on water-quality data collected by the U.S. Geological Survey (USGS) from 71 groundwater sites in 2012. Potential relations with natural and anthropogenic factors were examined with statistical tests and graphical analyses and were discussed in the context of the hydrogeologic setting of the study unit. For the fourth objective, results from the NSF-SA (domestic drinkingwater sources) assessments were compared to results from the GAMA-PBP assessment of the North San Francisco Bay Public-Supply Aquifer study unit (NSF-PA; public drinkingwater sources), for which data were collected in 2004. 
The status of the quality of the groundwater resource during 2012 was assessed by using data from samples analyzed for volatile organic compounds (VOCs), pesticides, and naturally present inorganic constituents, such as trace elements and major and minor ions. The status assessment characterized the quality of untreated groundwater resources in the shallow aquifer system of the NSF-SA, not the treated drinking water delivered to consumers by water purveyors. Relative concentrations (RCs; sample concentration divided by the health- or aesthetic-based benchmark concentration) were used for evaluating groundwater quality for those constituents that have Federal or California regulatory or non-regulatory benchmarks for drinking-water quality. The understanding assessment used statistical correlations between concentrations of constituents and values of selected potential explanatory factors to identify the factors potentially affecting the concentrations and distribution of constituents found at high RCs or, for organic constituents, with study unit detections greater than 10 percent. The potential explanatory factors evaluated were aquifer lithology, land use, hydrologic conditions, depth, groundwater age, and geochemical conditions.

Aquifer-scale proportion was used as the primary metric in the status assessment for evaluating groundwater quality at the study-unit scale or for its component areas. A stratified-random sampling design and grid-based statistical approach provided the basis for aquifer-scale proportions for individual constituents. The NSF-SA was divided into two study areas, and each was stratified using a grid of cells: the Highlands study area had 30 cells, and the Valleys and Plains study area had 40 cells. In each cell, one groundwater site (most often a well, but four springs were also sampled) was randomly selected to represent the groundwater resource used for domestic supply. Aquifer-scale proportion is defined as the percentage of the shallow aquifer system with a specified range of relative concentrations for a particular constituent or class of constituents; the proportion is based on an areal rather than a volumetric basis. RCs greater than 1.0 (exceeding the corresponding water-quality benchmark) were categorized as high. The threshold between moderate and low RCs was 0.5 for inorganic constituents and 0.1 for organic constituents. Corresponding moderate and low aquifer-scale proportions were defined as the percentages of the shallow aquifer system with moderate and low RCs, respectively. For grid-based areal proportions of the shallow aquifer with high RCs, the 90 -percent confidence intervals were calculated using the Jeffreys interval for all constituents.

Of 34 inorganic constituents with regulatory healthbased benchmarks (HBB), 12 were detected at moderate or high RCs. As a group, inorganic constituents with HBB were present at high $\mathrm{RCs}$ in 27 percent of the shallow aquifer system and at moderate RCs in 21 percent. The inorganic constituents with high aquifer-scale proportions included arsenic, boron, fluoride, manganese, and nitrate. The inorganic constituents with non-regulatory aesthetic-based benchmarks were present at high RCs in 24 percent of the shallow aquifer system and at moderate RCs in 16 percent. Iron, sulfate, and TDS were the constituents with high RCs.

One or more organic constituents were found in 29 of the 70 grid sites ( 41 percent) sampled in the study unit. Of the 20 organic constituents detected, 13 have regulatory healthbased benchmarks. These organic constituents as a group were found at high RCs in 1 percent of the shallow aquifer system. Organic constituents were not detected at moderate RCs. The insecticide dieldrin was the only constituent detected at high RCs, but was detected in one sample only (less than 1 percent of sites). Only one organic constituent had a detection frequency of greater than 10 percent - the trihalomethane chloroform.

Chloroform and perchlorate (a special-interest constituent) were detected in more than 10 percent of sites sampled in the NSF-SA. Chloroform concentrations were positively correlated with underground storage tank density and dissolved oxygen, had higher concentrations in groundwater classified as modern than in pre-modern and had higher concentrations in oxic than in anoxic groundwater. Perchlorate was positively correlated with nitrate, dissolved oxygen concentrations, and the percentage of urban land use and was negatively correlated with aridity index and $\mathrm{pH}$.

Groundwater age class (modern, mixed, or premodern), redox class (oxic or anoxic), aquifer lithology class (metamorphic, sedimentary, or volcanic), and dissolved oxygen concentrations were the best explanatory factors for distribution patterns of most of the inorganic constituents. Higher concentrations of arsenic and fluoride were primarily associated with groundwater classified as pre-modern rather than modern. Higher concentrations of boron, fluoride, and manganese were associated with anoxic redox conditions. Concentrations of arsenic, boron, fluoride, and manganese were all negatively correlated with dissolved oxygen concentrations. Similar patterns of association with explanatory variables were seen for inorganic constituents with aesthetic-based benchmarks detected at high concentrations. Iron, sulfate, and total dissolved solids were all higher in groundwater classified as anoxic with respect to redox conditions, and all were significantly negatively correlated with dissolved oxygen concentrations.

Comparison of the NSF-PA to the NSF-SA revealed some expected, yet subtle, differences between the hydrogeology in the deeper and more shallow aquifer systems. Characteristics like water type and redox conditions were relatively similar. For groundwater residence time in the aquifer since recharge, however, the NSF-PA had a greater proportion of groundwater age samples classified as pre-modern (52 percent) than the NSF-SA (33 percent), whereas in the NSF-SA, 35 percent of such samples were classified as modern, nearly twice the frequency as in the NSF-PA (19 percent). 
With respect to the water-quality results, tests using contingency tables identified significant differences in the frequencies of high and moderate RCs between study units and study areas. Comparisons at the study-unit scale showed significant differences in the frequency of high RCs of nitrate. High RCs of nitrate were more frequent in the NSF-SA, whereas organic constituents were detected at moderate RCs more frequently in the NSF-PA. For constituent classes, inorganic constituents with health-based benchmarks and trace elements with health-based benchmarks were both found more frequently at high RCs in the Valleys and Plains study area of the NSF-SA than in the NSF-PA Valleys and Plains. Arsenic and manganese were the inorganic constituents most frequently detected at high or moderate RCs in both study units, and greater frequency of high or moderate RCs of manganese in the NSF-SA Valleys and Plains study area contributed most to the difference between study areas. Nitrate was also detected more often at high RCs in the Valleys and Plains study area of the NSF-SA than in the Valleys and Plains study area of the NSF-PA. Total dissolved solids were only detected at high concentrations in the NSF-SA.

Frequencies of organic constituents at high RCs were low in both study units (less than 2 percent in each). The detection frequency of organic constituents (as a class) at low RCs was higher in the NSF-PA (34 percent) than in the NSF-SA (20 percent), which could reflect a greater percentage of urban land-use surrounding sites in the NSF-PA, thus making them more likely to be exposed to some classes of organic constituents by activities at the land surface. Chloroform was the only organic constituent detected in more than 10 percent of samples from both study units. The inorganic salt perchlorate was not detected in the NSF-PA, whereas in the NSF-SA, perchlorate was detected at low or moderate RCs in about 5 percent of the samples.

\section{References Cited}

Agency for Toxic Substances and Disease Registry, 2002, Public health statement for aldrin/dieldrin: U.S. Department of Health and Human Services, Agency for Toxic Substances and Disease Registry website, accessed January 13, 2016, at http://www.atsdr.cdc.gov/phs/phs.asp?id=315\&tid=56.

Appelo, C.A.J., and Postma, Dieke, 2005, Geochemistry, groundwater, and pollution ( $2 \mathrm{~d}$ ed.): Leiden, Germany, A.A. Balkema Publishers, 649 p.

Bailey, E.H., Irwin, W.P., and Jones, D.L., 1964, Franciscan and related rocks, and their significance in the geology of western California: California Division of Mines and Geology, Bulletin 183, v. 177, 2 pls., http://pubs.geothermal-library.org/lib/grc/1021053.pdf.
Belitz, Kenneth, Dubrovsky, N.M., Burow, Karen, Jurgens, Bryant, and Johnson, Tyler, 2003, Framework for a ground-water quality monitoring and assessment program for California: U.S. Geological Survey WaterResources Investigations Report 03-4166, 78 p., http://pubs.usgs.gov/wri/wri034166/.

Belitz, Kenneth, Jurgens, Bryant, Landon, M.K., Fram, M.S., and Johnson, Tyler, 2010, Estimation of aquifer scale proportion using equal-area grids-Assessment of regional scale groundwater quality: Water Resources Research, v. 46, no. 11, W11550, 14 p., http://dx.doi.org/10.1029/2010WR009321.

Belitz, Kenneth, Fram, M.S., and Johnson, T.D., 2015, Metrics for assessing the quality of groundwater used for public supply, CA, USA-Equivalent-population and area: Environmental Science and Technology, v. 49, no. 14, p. 8330-8338, http://dx.doi.org/10.1021/acs.est.5b00265.

Bennett, G.L., V., and Fram, M.S., 2014, Groundwater-quality data in the North San Francisco Bay Shallow Aquifer Study Unit, 2012-Results from the California GAMA Program: U.S. Geological Survey Data Series 865, 94 p., https://doi.org/10.3133/ds865.

Böhlke, J.K., Hatzinger, P.B., Sturchio, N.C., Baohua Gu, I.A., and Mroczkowski, S.J., 2009, Atacama perchlorate as an agricultural contaminant in groundwater-Isotopic and chronologic evidence from Long Island, New York: Environmental Science and Technology, v. 43, no. 15, p. 5619-5625, http://dx.doi.org/10.1021/es9006433.

Borchers, J.W., 1996, Ground-water resources and watersupply alternatives in the Wawona area of Yosemite National Park, California: U.S. Geological Survey WaterResources Investigations Report 95-4229, 77 p., http://pubs.er.usgs.gov/publication/wri954229.

Brown, L.D., Cai, T.T., and DasGupta, Anirban, 2001, Interval estimation for a binomial proportion: Statistical Science, v. 16, no. 2, p. 101-117, http://dx.doi.org/10.1214/ss/1009213286.

Burow, K.R., Jurgens, B.C., Kauffman, L.J., Phillips, S.P, Dalgish, B.A., and Shelton, J.L., 2008, Simulations of ground-water flow and particle pathline analysis in the zone of contribution of a public-supply well in Modesto, Eastern San Joaquin Valley, California: U.S. Geological Survey Scientific Investigations Report 2008-5035, 41 p., https://pubs.usgs.gov/sir/2008/5035/.

Burton, C.A., Shelton, J.L., and Belitz, Kenneth, 2012, Status and understanding of groundwater quality in the two southern San Joaquin Valley study units, 2005-2006California GAMA Priority Basin Project: U.S. Geological Survey Scientific Investigations Report 2011-5218, 106 p., http://pubs.usgs.gov/sir/2011/5218/. 
California Department of Pesticide Regulation, 2015, Pesticide use reporting: California Department of Pesticide Regulation website, accessed July 2015 at http://www.cdpr.ca.gov/docs/pur/purmain.htm.

California Department of Water Resources, 2003, California's groundwater: California Department of Water Resources Bulletin 118, 246 p., accessed July 2, 2014, at http://www.water.ca.gov/groundwater/.

California Department of Water Resources, 2004a, California's groundwater-Individual basin descriptions, Santa Rosa Valley, Santa Rosa Plain subbasin: California Department of Water Resources Bulletin 118, accessed September 2016 at http://www.water.ca.gov/groundwater/bulletin118/ basindescriptions/1-55.01.pdf.

California Department of Water Resources, 2004b, California's groundwater-Individual basin descriptions, Santa Rosa Valley, Healdsburg Area subbasin: California Department of Water Resources Bulletin 118, accessed September 2016 at http://www.water.ca.gov/groundwater/ bulletin118/basindescriptions/1-55.02.pdf.

California Department of Water Resources, 2004c, California's groundwater-Individual basin descriptions, Santa Rosa Valley, Rincon Valley subbasin: California Department of Water Resources Bulletin 118, accessed September 2016 at http://www.water.ca.gov/groundwater/bulletin118/ basindescriptions/1-55.03.pdf.

California Department of Water Resources, 2004d, California's groundwater-Individual basin descriptions, Alexander Valley groundwater basin, Alexander subbasin: California Department of Water Resources Bulletin 118, accessed September 2016 at http://www.water.ca.gov/ groundwater/bulletin118/basindescriptions/1-54.01.pdf.

California Department of Water Resources, 2004e, California's groundwater-Individual basin descriptions, Alexander Valley groundwater basin, Cloverdale Area subbasin: California Department of Water Resources Bulletin 118, accessed September 2016 at http://www.water.ca.gov/ groundwater/bulletin118/basindescriptions/1-54.02.pdf.

California Department of Water Resources, 2014a, California's groundwater-Individual basin descriptions, Napa-Sonoma Valley groundwater basin, Napa Valley subbasin: California Department of Water Resources Bulletin 118, accessed September 2016 at http://www.water.ca.gov/groundwater/ bulletin118/basindescriptions/2-02.01.pdf.

California Department of Water Resources, 2014b, California's groundwater-Individual basin descriptions, Napa-Sonoma Valley groundwater basin, Sonoma Valley subbasin: California Department of Water Resources Bulletin 118, accessed September 2016 at http:/www.water.ca.gov/groundwater/bulletin118/ basindescriptions/2-02.02.pdf.
California Department of Water Resources, 2014c, California's groundwater-Individual basin descriptions, Napa-Sonoma Valley groundwater basin, Napa-Sonoma Lowlands subbasin: California Department of Water Resources Bulletin 118, accessed September 2016 at http://www.water.ca.gov/groundwater/bulletin118/ basindescriptions/2-02.03.pdf.

California Department of Water Resources, 2014d, California's groundwater-Individual basin descriptions, Kenwood Valley groundwater basin: California Department of Water Resources Bulletin 118, accessed September 2016 at http://www.water.ca.gov/groundwater/bulletin118/ basindescriptions/2-19.pdf.

California Department of Water Resources, 2014e, California's groundwater-Individual basin descriptions, Petaluma Valley groundwater basin: California Department of Water Resources Bulletin 118, accessed September 2016 at http:/www.water.ca.gov/groundwater/bulletin118/ basindescriptions/2-01.pdf.

California Department of Water Resources, 2014f, California's groundwater-Individual basin descriptions, Wilson Grove Formation Highlands groundwater basin: California Department of Water Resources Bulletin 118, accessed September 2016 at http://www.water.ca.gov/groundwater/ bulletin118/basindescriptions/1-59.pdf.

California Department of Water Resources, 2016, Groundwater Information Center: California Department of Water Resources website, accessed September 2016 at http://www.water.ca.gov/groundwater/gwinfo/.

California Division of Mines and Geology, 1984, Geothermal resource investigations of the Sonoma Valley area, Sonoma and Napa Counties, California: California Division of Mines and Geology Open File Report 84-29.

California State Water Resources Control Board, 2003, A comprehensive groundwater quality monitoring program for California: Assembly Bill 599 Report to the Governor and Legislature, March 2003, 100 p., http://www.waterboards.ca.gov/gama/docs/final_ab_599 rpt_to_legis_7_31_03.pdf.

California State Water Resources Control Board, 2007, History of perchlorate in California drinking water: California State Water Resources Control Board website, accessed May 4, 2015, at http://www.waterboards.ca.gov/drinking_water/certlic/ drinkingwater/Perchloratehistory.shtml.

California State Water Resources Control Board, 2015a, California drinking water-related laws-Drinking waterrelated statutes and regulations: California State Water Resources Control Board website, accessed January 2016 at http://www.waterboards.ca.gov/drinking_water/certlic/ drinkingwater/Lawbook.shtml. 
California State Water Resources Control Board, 2015b, Perchlorate in drinking water: California State Water Resources Control Board website, accessed May 4, 2015, at http://www.waterboards.ca.gov/drinking water/certlic/ drinkingwater/Perchlorate.shtml.

Cardwell, G.T., 1958, Geology and ground water in Santa Rosa and Petaluma Valley areas, Sonoma County, California: U.S. Geological Survey Water Supply Paper 1427, 273 p., http://pubs.er.usgs.gov/publication/wsp1427.

Centers for Disease Control and Prevention and U.S. Department of Housing and Urban Development, 2006, Healthy housing reference manual: U.S. Department of Health and Human Services, 231 p.

Chin, Mian, and Davis, D.D., 1993, Global sources and sinks of OCS and $\mathrm{CS}_{2}$ and their distributions: Global Biogeochemical Cycles, v. 7, no. 2, p. 321-337, http://dx.doi.org/10.1029/93GB00568.

Dasgupta, P.K., Martinelango, P.K., Jackson, W.A., Anderson, T.A., Tian, Kang, Tock, R.W., and Rajogopalan, Srinath, 2005, The origin of naturally occurring perchlorate-The role of the atmospheric processes: Environmental Science and Technology, v. 39, no. 6, p. 1569-1575, http://dx.doi.org/10.1021/es048612x.

Dasgupta, P.K., Dyke, J.V., Kirk, A.B., and Jackson, W.A., 2006, Perchlorate in the United States-Analysis of relative source contributions to the food chain: Environmental Science and Technology, v. 40, no. 21, p. 6608-6614, http://dx.doi.org/10.1021/es061321z.

Devai, Istvan, and DeLaune, R.D., 1995, Formation of volatile sulfur compounds in salt marsh sediment as influenced by soil redox condition: Organic Geochemistry, v. 23, no. 4, p. 238-287, https://doi.org/10.1016/0146-6380(95)00024-9.

Dubrovsky, N.M., Burow, K.R., Clark, G.M., Gronberg, J.M., Hamilton, P.A., Hitt, K.J., Mueller, D.K., Munn, M.D., Nolan, B.T., Puckett, L.J., Rupert, M.G., Short, T.M., Spahr, N.E., Sprague, L.A., and Wilber, W.G., 2010, The quality of our Nation's waters-Nutrients in the Nation's streams and groundwater, 1992-2004: U.S. Geological Survey Circular 1350, 174 p., http://pubs.er.usgs.gov/publication/cir1350.

Farrar, C.D., Metzger, L.F., Nishikawa, Tracy, Koczot, K.M., and Reichard, E.G., 2006, Geohydrologic characterization, water-chemistry, and ground-water flow simulation model of the Sonoma Valley area, Sonoma County, California, with a section on Basement rock configuration interpreted from gravity data, by Victoria E. Langenheim: U.S. Geological Survey Scientific Investigations Report 2006-5092, 167 p., http://pubs.usgs.gov/sir/2006/5092/.
Faye, R.E., 1973, Ground-water hydrology of the northern Napa Valley, California: U.S. Geological Survey WaterResources Investigations Report 73-13, 64 p.

Focazio, M.J., Welch, A.H., Watkins, S.A., Helsel, D.R., and Horn, M.A., 2000, A retrospective analysis on the occurrence of arsenic in ground-water resources of the United States and limitations in drinking-water-supply characterizations: U.S. Geological Survey WaterResources Investigations Report 99-4279, 21 p., http://pubs.usgs.gov/wri/wri994279/.

Forrest, M.J., Kulongoski, J.T., Edwards, M.S., Farrar, C.D., Belitz, K., and Norris, R.D., 2013, Hydrothermal contamination of public supply wells in Napa and Sonoma Valleys, California: Applied Geochemistry, v. 33, p. 25-40, https://doi.org/10.1016/j.apgeochem.2013.01.012.

Fox Jr, K.F., 1983, Tectonic setting of late Miocene, Pliocene, and Pleistocene rocks in part of the Coast Ranges north of San Francisco, California: U.S. Geological Survey Professional Paper 1239, 33 p., http://pubs.usgs.gov/pp/1239/report.pdf.

Fram, M.S., and Belitz, Kenneth, 2011, Probability of detecting perchlorate under natural conditions in deep groundwater in California and the southwestern United States: Environmental Science and Technology, v. 45, no. 4, p. 1271-1277, http://dx.doi.org/10.1021/es103103p.

Fram, M.S., and Belitz, Kenneth, 2012, Status and understanding of groundwater quality in the TahoeMartis, Central Sierra, and Southern Sierra study units, 2006-2007-California GAMA Priority Basin Project: U.S. Geological Survey Scientific Investigations Report 2011-5216, 222 p., http://pubs.usgs.gov/sir/2011/5216/.

Freeze, R.A., and Cherry, J.A., 1979, Groundwater: Englewood Cliffs, New Jersey, Prentice Hall, Inc., 604 p.

Gascoyne, Mel, 1997, Evolution of redox conditions and groundwater composition in recharge-discharge environments on the Canadian Shield: Hydrogeology Journal, v. 5, no. 3, p. 4-18.

Gilliom, R.J., Barbash, J.E., Crawford, C.G., Hamilton, P.A., Martin, J.D., Nakagaki, Naomi, Nowell, L.H., Scott, J.C., Stackelberg, P.E., Thelin, G.P., and Wolock, D.M., 2006, The quality of our nation's waters-Pesticides in the nation's streams and ground water, 1992-2001: U.S. Geological Survey Circular 1291, 173 p., http://pubs.usgs.gov/circ/2005/1291/.

Helsel, D.R., and Hirsch, R.M., 2002, Statistical methods in water resources: U.S. Geological Survey Techniques of Water Resources Investigations, book 4, chap. A3, 522 p., http://pubs.usgs.gov/twri/twri4a3/. 
Hem, J.D., 1985, Study and interpretation of the chemical characteristics of natural water ( $3 \mathrm{~d}$ ed.): U.S. Geological Survey Water Supply Paper 2254, 263 p., http://pubs.er.usgs.gov/publication/wsp2254.

Hirsch, R.M., Alley, W.M., and Wilber, W.G., 1988, Concepts for a National Water-Quality Assessment Program: U.S. Geological Survey Circular 1021, 42 p., https://pubs.er.usgs.gov/publication/cir1021.

Ingebritsen, S.E., and Sanford, W.E., 1998, Groundwater in geologic processes: New York, Cambridge University Press, $341 \mathrm{p}$.

Jennings, C.W., 1977, Geologic map of California: California Department of Conservation, Division of Mines and Geology Geologic data map no. 2, scale 1:750,000, http:// www.quake.ca.gov/gmaps/GMC/stategeologicmap.html.

Jin, Suming, Yang, Limin, Danielson, Patrick, Homer, Collin, Fry, Joyce, and Xian, George, 2013, A comprehensive change detection method for updating the National Land Cover Database to circa 2011: Remote Sensing of Environment, v. 132, p. 159-175, http://www.mrlc.gov/nlcd2011.php.

Johnson, T.D., and Belitz, Kenneth, 2009, Assigning land use to supply wells for the statistical characterization of regional groundwater quality - Correlating urban land use and VOC occurrence: Journal of Hydrology, v. 370, p. 100-108, http://ca.water.usgs.gov/projects/gama/pdfs/ Johnson_2009_1-s2.0-S0022169409001462-main.pdf.

Johnson, T.D., and Belitz, Kenneth, 2014, California groundwater units: U.S. Geological Survey Data Series 796, 34 p., https://doi.org/10.3133/ds796.

Jurgens, B.C., McMahon, P.B., Chapelle, F.H., and Eberts, S.M., 2009, An Excel ${ }^{\circledR}$ workbook for identifying redox processes in ground water: U.S. Geological Survey Open-File Report 2009-1004, 8 p., http://pubs.usgs.gov/of/2009/1004/.

Kim, Kangjoo, and Jeong, G.Y., 2005, Factors influencing natural occurrence of fluoride-rich groundwaters-A case study in the southeastern part of the Korean Peninsula: Chemosphere, v. 58, no. 10, p. 1399-1408, https://doi.org/10.1016/j.chemosphere.2004.10.002.

Klein, Cornelus, and Hurlbut, C.S., Jr., 1993, Manual of mineralogy (after James D. Dana), 21st ed.: New York, John Wiley \& Sons, $681 \mathrm{p}$.

Kulongoski, J.T., Belitz, Kenneth, and Dawson, B.J., 2006, Ground-water quality data in the North San Francisco Bay hydrologic provinces, California, 2004-Results from the Ground-Water Ambient Monitoring and Assessment (GAMA) Program: U.S. Geological Survey Data Series Report 167, 100 p., http://pubs.usgs.gov/ds/ds167/.
Kulongoski, J.T., Belitz, Kenneth, Landon, M.K., and Farrar, Christopher, 2010, Status and understanding of groundwater quality in the North San Francisco Bay groundwater basins, 2004-California GAMA Priority Basin Project: U.S. Geological Survey Scientific Investigations Report 2010-5089, 88 p., http://pubs.usgs.gov/sir/2010/5089/.

Kunkel, Fred, and Upson, J.E., 1960, Geology and ground water in Napa and Sonoma Valleys, Napa and Sonoma Counties, California: U.S. Geological Survey Water Supply Paper 1495, 252 p., http://pubs.er.usgs.gov/publication/wsp1495.

Landon, M.K., Belitz, Kenneth, Jurgens, B.C., Kulongoski, J.T., and Johnson, T.D., 2010, Status and understanding of groundwater quality in the CentralEastside San Joaquin Basin, 2006-California GAMA Priority Basin Project: U.S. Geological Survey Scientific Investigations Report 2009-5266, 97 p., http://pubs.usgs.gov/sir/2009/5266/.

Landon, M.K., Green, C.T., Belitz, Kenneth, Singleton, M.J., and Esser, B.K., 2011, Relations of hydrogeologic factors, groundwater reduction-oxidation conditions, and temporal and spatial distributions of nitrate, Central-Eastside San Joaquin Valley, California, USA: Hydrogeology Journal, v. 19 , no. 6, p. 1203-1224, http://link.springer.com/article/1 0.1007\%2Fs10040-011-0750-1.

Loebenstein, J.R., 1994, Materials flow of arsenic in the United States: U.S. Department of the Interior, Bureau of Mines, Division of Mineral Commodities Information Circular 9382, 12 p., http://pubs.usgs.gov/usbmic/ic-9382/.

McMahon, P.B., and Chapelle, F.H., 2008, Redox processes and water quality of selected principal aquifer systems: Ground Water, v. 46, no. 2, p. 29-271.

Metzger, L.F., Farrar, C.D., Koczot, K.M., and Reichard, E.G., 2006, Geohydrology and water-chemistry of the Alexander Valley, Sonoma County, California: U.S. Geological Survey Scientific Investigations Report 2006-5115, 83 p., https://pubs.usgs.gov/sir/2006/5115/.

Mueller, D.K., and Helsel, D.R., 1996, Nutrients in the Nation's waters - Too much of a good thing?: U.S. Geological Survey Circular 1136, 24 p., http://pubs.usgs.gov/circ/circ1136/.

Nolan, B.T., Hitt, K.J., and Ruddy, B.C., 2002, Probability of nitrate contamination of recently recharged groundwaters in the conterminous United States: Environmental Science \& Technology, v. 36, no. 10, p. 2138-2145, http://dx.doi.org/10.1021/es0113854. 
Nordstrom, D.K., Ball, J.W., Donahoe, R.J., and Whittemore, Donald, 1989, Groundwater chemistry and water-rock interaction at Stripa: Geochimica et Cosmochimica Acta, v. 53, no. 8, p. 1727-1740, https://doi.org/10.1016/0016-7037(89)90294-9.

Page, R.W., Anttila, P.W., Johnson, K.L., and Pierce, M.J., 1984, Ground-water conditions and well yields in fractured rocks, southwestern Nevada County, California: U.S. Geological Survey WaterResources Investigations Report 83-4262, 38 p., http://pubs.er.usgs.gov/publication/wri834262/.

Parker, D.R, Seyfferth, A.L., and Reese, B.K., 2008, Perchlorate in groundwater-A synoptic survey of "pristine" sites in the conterminous Unites States: Environmental Science and Technology, v. 42, no. 5, p. 1465-1471, http://doi.org/10.1021/es7021957.

Rajagopalan, Srinath, Anderson, Todd, Cox, Stephen, Harvey, Greg, Chen, Qiuqiong, and Jackson, W.A., 2009, Perchlorate in wet deposition across North America: Environmental Science and Technology, v. 43, no. 3, p. 616-622, http://dx.doi.org/10.1021/es801737u.

Rao, Balaji, Anderson, T.A., Orris, G.J, Rainwater, K.A., Rajagopalan, Srinath, Sandvig, R.M., Scanlon, B.R., Stonestrom, D.A., Walvoord, M.A., and Jackson, W.A., 2007, Widespread natural perchlorate in unsaturated zones of the southwest United States: Environmental Science and Technology, v. 41, no. 13, p. 4522-4528, http://dx.doi.org/10.1021/es062853i.

Rowe, B.L., Toccalino, P.L., Moran, M.J., Zogorski, J.S., and Price, C.V., 2007, Occurrence and potential human-health relevance of volatile organic compounds in drinking water from domestic wells in the United States: Environmental Health Perspectives, v. 115, no. 11, p. 1539-1546, http://www.ncbi.nlm.nih.gov/pmc/articles/PMC2072842/.

Saucedo, G.J., Bedford, D.R., Raines, G.L., Miller, R.J., and Wentworth, C.M., 2000, GIS data for the geologic map of California (version 2.0): California Department of Conservation, Division of Mines and Geology, CD-ROM 2000-007.

Scott, J.C., 1990, Computerized stratified random siteselection approaches for design of a ground-water-quality sampling network: U.S. Geological Survey WaterResources Investigations Report 90-4101, 109 p., http://pubs.er.usgs.gov/publication/wri904101.

Sidborn, M., and Neretnieks, I., 2007, Long term redox evolution in granitic rocks-Modeling the redox front propagation in the rock matrix: Applied Geochemistry, v. 22, no. 11, p. 2381-2396, https://doi.org/10.1016/j.apgeochem.2007.05.007.
Smedley, P.L., and Kinniburgh, D.G., 2002, A review of the source, behaviour and distribution of arsenic in natural waters: Applied Geochemistry, v. 17, no. 5, p. 517-568, https://doi.org/10.1016/S0883-2927(02)00018-5.

Sonoma County Water Agency, 2013, Sonoma Valley salt and nutrient management plan final report: Prepared for the Sonoma Valley County Sanitation District, accessed October 2016 at http://www.scwa.ca.gov/SNMP/.

State of California, 1999, Supplemental report of the 1999 Budget Act 1999-00 Fiscal Year, Item 3940-001-0001: State Water Resources Control Board, accessed May 19, 2015, at http://www.lao.ca.gov/1999/99-00_supp_rpt_lang. html\#3940.

State of California, 2001a, Assembly Bill No. 599, chapter 522: accessed May 19, 2015, at http://www.swrcb. ca.gov/gama/docs/ab_599_bill_20011005_chaptered.pdf.

State of California, 2001b, Groundwater Monitoring Act of 2001: California Water Code, part 2.76, sections 10780 10782.3, accessed May 19, 2015, at http://leginfo. legislature.ca.gov/faces/billTextClient.xhtml?bill $\mathrm{id}=200120020$ AB599\&search_keywords $=$ Groundwater + M onitoring.

Stumm, Werner, and Morgan, J.J., 1996, Aquatic chemistry, chemical equilibria and rates in natural waters: New York, John Wiley \& Sons, 1022 p.

Toccalino, P.L., and Norman, J.E., 2006, Health-based screening levels to evaluate U.S. Geological Survey groundwater quality data: Risk Analysis, v. 26, no. 5, p. $1339-1348$.

Toccalino, P.L., Norman, J.E., Phillips, R.H., Kauffman, L.J., Stackelberg, P.E., Nowell, L.H., Krietzman, S.J., and Post, G.B., 2004, Application of health-based screening levels to ground-water quality data in a state-scale pilot effort: U.S. Geological Survey Scientific Investigations Report 2004-5174, 64 p., http://pubs.usgs.gov/sir/2004/5174/.

Toccalino, P.L., Norman, J.E., and Schoephoester, K.M., 2014, Health-based screening levels for evaluating waterquality data: U.S. Geological Survey website, accessed at http://water.usgs.gov/nawqa/HBSL.

United Nations Educational, Scientific, and Cultural Organization (UNESCO), 1979, Map of the world distribution of arid regions - Explanatory note: Man and the Biosphere (MAB) Technical Notes, Paris, v. 7, 42 p.

United Nations Environment Programme, 1997, World atlas of desertification, 2d ed.: London, Edward Arnold, 182 p. 
U.S. Census Bureau, 1992, Census of population and housing, 1990 - Summary tape file 3A: Washington, D.C., U.S. Census Bureau, machine-readable data, accessed May 19, 2015, at ftp://ftp2.census.gov/census_1990/.

U.S. Department of Commerce, National Climatic Data Center, 2012: U.S. Department of Commerce website, accessed May 19, 2015, at http://www.ncdc.noaa.gov/.

U.S. Environmental Protection Agency, 1972, Arsenical pesticides, man, and the environment: U.S. Environmental Protection Agency, Office of Pesticide Programs, 166 p., accessed July 2015 at http://nepis.epa.gov/Exe/ZyPURL. cgi?Dockey=9100CC80.txt.

U.S. Environmental Protection Agency, 1986, Guidelines for the health risk assessment of chemical mixtures: U.S. Environmental Protection Agency, Office of Research and Development, Risk Assessment Forum EPA/630/R-98/002, September 1986, 38 p., accessed July 2015 at https://www.epa.gov/risk/guidelines-healthrisk-assessment-chemical-mixtures.

U.S. Environmental Protection Agency, 2001, Technical Fact Sheet-Final rule for arsenic in drinking water: U.S. Environmental Protection Agency website, accessed March 22, 2016, at http://nepis.epa.gov/Exe/ZyPdf. cgi? Dockey=20001XXE.txt.

U.S. Environmental Protection Agency, 2005, List of known perchlorate releases in the U.S.: U.S. Environmental Protection Agency website, accessed November 10, 2016, at https:/clu-in.org/download/contaminantfocus/perchlorate/ detect0305.pdf.

U.S. Environmental Protection Agency, 2008, Drinking water health advisory for boron: U.S. Environmental Protection Agency 822-R-08-013, 53 p., http://www.epa.gov/sites/ production/files/2014-09/documents/drinking_water_ health_advisory_for_boron.pdf.

U.S. Environmental Protection Agency, 2012, 2012 Edition of the drinking water standards and health advisories: U.S. Environmental Protection Agency website, accessed at https://nepis.epa.gov/Exe/ZyPDF.cgi/P100N01H. PDF?Dockey=P100N01H.PDF.

U.S. Environmental Protection Agency, 2016, National primary drinking water regulations: Code of Federal Regulations, Title 40, Part 141, accessed July 2016 at http://www.ecfr.gov/cgi-bin/text-idx?SID=0ee8e46e25bd39 $\mathrm{f} 1577864 \mathrm{c} 8376 \mathrm{c} 8607 \& \mathrm{mc}=$ true $\&$ node $=\mathrm{pt} 40.25 .141 \& \mathrm{rgn}=\mathrm{d}$ iv5\#sp40.25.141.g.
U.S. Geological Survey, 2005, Mineral Resources Data System: U.S. Geological Survey website, accessed August 2015 at http://mrdata.usgs.gov/mrds/.

Weaver, C.E., 1949, Geology of the Coast Ranges immediately north of the San Francisco Bay region, California: Geologic Society of America Memoir, v. 35, 242 p., http://memoirs. gsapubs.org/content/35/local/front-matter.pdf.

Welch, A.H., and Stollenwerk, K.G., eds., 2003, Arsenic in ground water-Geochemistry and occurrence: Springer, $475 \mathrm{p}$.

Welch, A.H., Westjohn, D.B., Helsel, D.R., and Wanty, R.B., 2000, Arsenic in ground water of the United StatesOccurrence and geochemistry: Ground Water, v. 38, no. 4, p. 589-604, http://water.usgs.gov/nawqa/trace/pubs/gw_ v38n4/GW_vol38no4.pdf.

Welch, A.H., Oremland, R.S., Davis, J.A., and Watkins, S.A., 2006, Arsenic in groundwater-A review of the current knowledge and relation to the CALFED solution area with recommendations for needed research: San Francisco Estuary \& Watershed Science, v. 4, no. 2, article 4, 32 p.

Western Regional Climate Center, 2016, Climate of California: Western Regional Climate Center website, accessed September 2016 at http://www.wrcc.dri.edu/Climate/narrative_ca.php.

Woolfenden, L.R., and Nishikawa, Tracy, eds., 2014, Simulation of groundwater and surface-water resources of the Santa Rosa Plain watershed, Sonoma County, California: U.S. Geological Survey Scientific Investigations Report 2014-5052, 258 p., https://doi.org/10.3133/sir20145052.

Youngs, L.G., Campion, L.F., Chapman, R.H., Higgins, C.T., Levias, E., Chase, G.W., and Bezore, S.P., 1983, Geothermal resources of the northern Sonoma Valley area, California: California Division of Mines and Geology, Open File Report 83-27, 106 p., 6 plates.

Zogorski, J.S., Carter, J.M., Ivahnenko, Tamara, Lapham, W.W., Moran, M.J., Rowe, B.L., Squillace, P.J., and Toccalino, P.L., 2006, Volatile organic compounds in the Nation's ground water and drinking-water supply wells: U.S. Geological Survey Circular 1292, 101 p., http://pubs.usgs.gov/circ/circ1292/. 
Table 1. Summary of groundwater sites, water-quality constituent groups, and numbers of constituents sampled for each constituent group by the U.S. Geological Survey (USGS) in the North San Francisco Bay Shallow Aquifer study unit (NSF-SA), 2012, California Groundwater Ambient Monitoring and Assessment (GAMA) Program Priority Basin Project.

[Unless otherwise noted, constituent analyses were performed at the USGS National Water Quality Laboratory, Denver, Colo. Abbreviations: B, boron; $\mathrm{C}$, carbon; H, hydrogen; $\mathrm{O}$, oxygen; $\mathrm{Sr}$, strontium; $\delta$, delta notation, indicating the isotopic enrichment or depletion of a sample relative to a standard of known composition]

\begin{tabular}{|c|c|}
\hline \multicolumn{2}{|l|}{ Site summary } \\
\hline Total number of sites & 71 \\
\hline Number of grid sites sampled & 70 \\
\hline Number of extra sites sampled & 1 \\
\hline Constituents & $\begin{array}{c}\text { Number of } \\
\text { constituents analyzed }\end{array}$ \\
\hline \multicolumn{2}{|l|}{ Inorganic constituents } \\
\hline $\begin{array}{l}\text { Alkalinity, bicarbonate, carbonate, and total } \\
\text { dissolved solids (TDS) }\end{array}$ & 4 \\
\hline Gross-alpha and gross-beta radioactivity ${ }^{1}$ & 2 \\
\hline Trace elements and major and minor ions & 33 \\
\hline Nutrients & 5 \\
\hline Perchlorate & 1 \\
\hline Radon-222 & 1 \\
\hline Specific conductance (field) ${ }^{2}$ & 1 \\
\hline \multicolumn{2}{|l|}{ Organic constituents } \\
\hline Pesticides and pesticide degradates & 63 \\
\hline Volatile organic compounds (VOCs) $^{3}$ & 85 \\
\hline \multicolumn{2}{|l|}{ Tracers } \\
\hline$\delta^{11} \mathrm{~B}$ in water ${ }^{4}$ & 1 \\
\hline Carbon-14 and $\delta^{13} \mathrm{C}$ of dissolved carbonates & 2 \\
\hline $\begin{array}{l}\text { Dissolved oxygen, } \mathrm{pH} \text {, and water } \\
\text { temperature (field) })^{2}\end{array}$ & 3 \\
\hline$\delta^{2} \mathrm{H}$ and $\delta^{18} \mathrm{O}$ stable isotopes of water & 2 \\
\hline${ }^{87} \mathrm{Sr} /{ }^{86} \mathrm{Sr}$ of dissolved strontium ${ }^{4}$ & 1 \\
\hline Tritium $^{5}$ & 1 \\
\hline Sum & 205 \\
\hline
\end{tabular}

${ }^{1}$ Gross-alpha and gross-beta particle activities were measured after 72-hour and 30-day holding times; data from the 72-hour measurements are used in this report.

${ }^{2}$ Analyzed by USGS field staff.

${ }^{3}$ Includes 10 constituents classified as fumigants or fumigant synthesis byproducts.

${ }^{4}$ Analyzed at the USGS Metals Isotope Research Lab, Menlo Park, California.

${ }^{5}$ Analyzed at U.S. Geological Survey Stable Isotope and Tritium Laboratory, Menlo Park, California. 
Table 2. Benchmark type and value for water-quality constituents present at high or moderate relative concentrations in samples from grid sites and for organic constituents present at any concentration in more than 10 percent of samples from the North San Francisco Bay Shallow Aquifer study unit (NSF-SA), 2012, California Groundwater Ambient Monitoring and Assessment (GAMA) Program Priority Basin Project.

[Relative concentration $(\mathrm{RC})$ is defined as the measured value divided by the benchmark value. For inorganic constituents, $\mathrm{RC}>1.0$ is defined as high and $1 \geq R C>0.5$ is defined as moderate. For organic constituents, $R C>1.0$ is defined as high and $1 \geq R C>0.1$ is defined as moderate. Benchmark types: Regulatory, health-based benchmarks: MCL-CA, SWRCB-DDW maximum contaminant level; MCL-US, EPA maximum contaminant level. Non-regulatory healthbased benchmarks: HBSL, U.S. Geological Survey (USGS) Health Based Screening Level; NL-CA, SWRCB-DDW notification level. Non-regulatory aesthetic-based benchmarks: SMCL-CA, SWRCB-DDW secondary maximum contaminant level. Abbreviations: EPA, U.S. Environmental Protection Agency; mg/L, milligrams per liter; pCi/L, picocuries per liter; SWRCB-DDW, California State Water Resources Control Board Division of Drinking Water; $\mu \mathrm{g} / \mathrm{L}$, micrograms per liter; >, greater than; $\geq$, greater than or equal to]

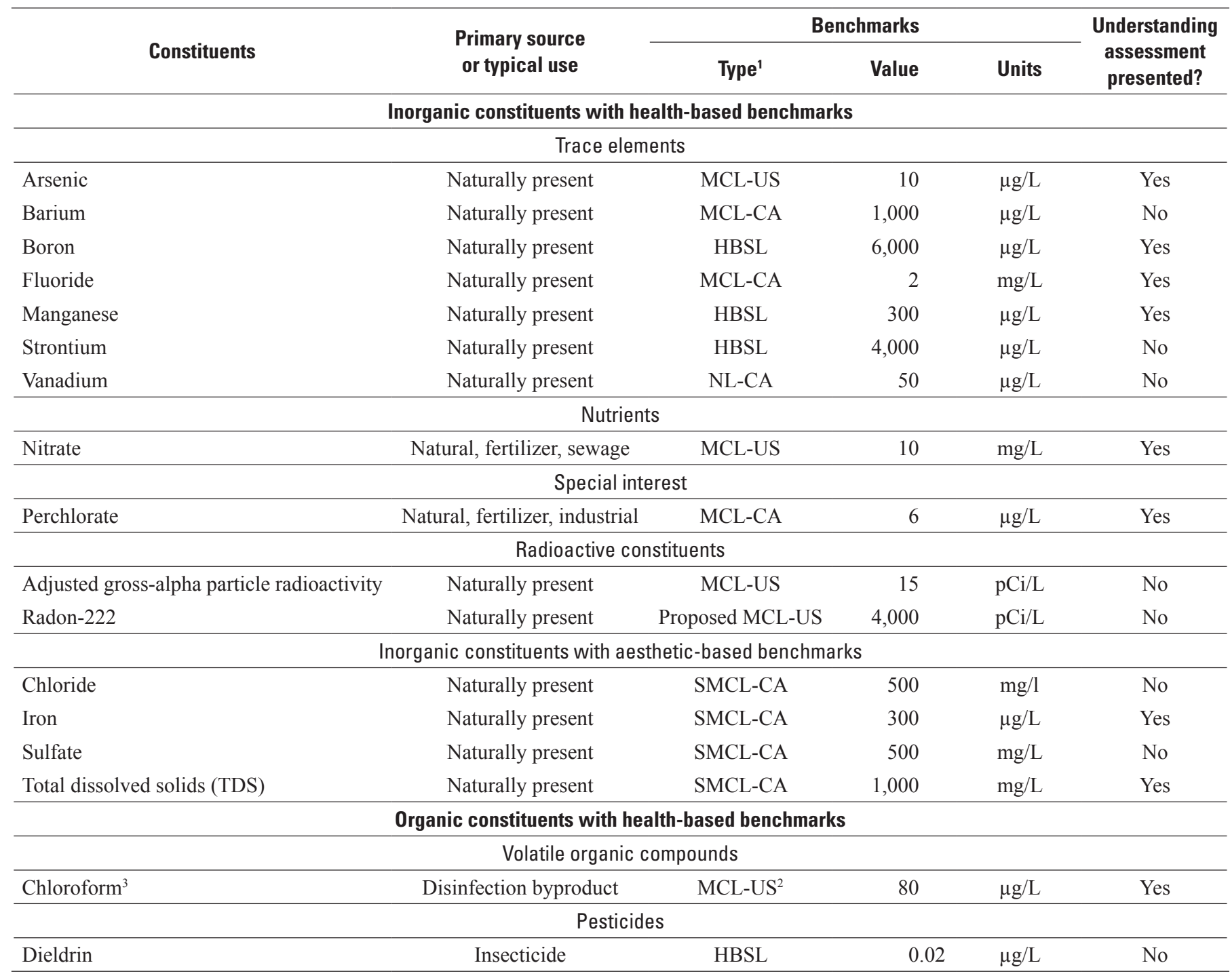

${ }^{1}$ Maximum contaminant level benchmarks are listed as MCL-US when the MCL-US and MCL-CA are identical, and as MCL-CA when the MCL-CA is lower than the MCL-US or no MCL-US exists. Sources of benchmarks: MCL-CA, California State Water Resources Control Board (2015a); MCL-US, U.S. Environmental Protection Agency (2012b); NL-CA, California State Water Resources Control Board (2015a); Proposed MCL-US, U.S. Environmental Protection Agency (1999); SMCL-CA, California State Water Resources Control Board (2015a).

${ }^{2}$ MCL-US benchmark for trihalomethanes is for the sum of chloroform, bromodichloromethane, dibromochloromethane, and bromoform.

${ }^{3}$ Chloroform is the only constituent within the volatile organic compound class to have been detected in more than 10 percent of the samples collected. 
Table 3. Benchmark type and value for water-quality constituents present only at low relative concentrations or lacking benchmarks and detected in samples collected for the North San Francisco Bay Shallow Aquifer study unit (NSF-SA), 2012, California Groundwater Ambient Monitoring and Assessment (GAMA) Program Priority Basin Project.

[Relative concentration $(\mathrm{RC})$ is defined as the measured value divided by the benchmark value. For inorganic constituents, $\mathrm{RC}>1.0$ is defined as high and $1 \geq R C>0.5$ is defined as moderate. For organic constitutents, $R C>1.0$ is defined as high and $1 \geq R C>0.1$ is defined as moderate. Benchmark types: Regulatory, health-based benchmarks: AL-US, EPA action level; HAL-US, EPA lifetime health advisory level; MCL-CA, SWRCB-DDW maximum contaminant level; MCL-US, EPA maximum contaminant level. Non-regulatory health-based benchmarks: HBSL, USGS Health Based Screening Level; NL-CA, SWRCBDDW notification level. Abbreviations: B, boron; C, carbon; EPA, U.S. Environmental Protection Agency; H, hydrogen; mg/L, milligrams per liter; na, not available; O, oxygen; pCi/L, picocuries per liter; Sr, strontium; SWRCB-DDW, California State Water Resources Control Board Division of Drinking Water; $>$, greater than; $\geq$, greater than or equal to; $\mu \mathrm{g} / \mathrm{L}$, micrograms per liter]

\begin{tabular}{|c|c|c|c|c|c|c|c|}
\hline \multirow{2}{*}{ Constituents } & \multicolumn{3}{|c|}{ Benchmarks } & \multirow{2}{*}{ Constituents } & \multicolumn{3}{|c|}{ Benchmarks } \\
\hline & Type $^{1}$ & Value & Units & & Type $^{1}$ & Value & Units \\
\hline \multicolumn{4}{|c|}{ Inorganic constituents with benchmarks } & \multicolumn{4}{|c|}{ Inorganic constituents without benchmarks-Continued } \\
\hline Ammonia & HAL-US & ${ }^{1} 24.7$ & $\mathrm{mg} / \mathrm{L}$ & Lithium & na & na & na \\
\hline Antimony & MCL-US & 6 & $\mu \mathrm{g} / 1$ & Magnesium & na & na & na \\
\hline Cadmium & MCL-US & 5 & $\mu \mathrm{g} / 1$ & Potassium & na & na & na \\
\hline Chromium & MCL-CA & 50 & $\mu \mathrm{g} / 1$ & Silica & na & na & na \\
\hline Copper & AL-US & 1,300 & $\mu \mathrm{g} / 1$ & Sodium & na & na & na \\
\hline Fluoride & MCL-CA & 2 & $\mathrm{mg} / \mathrm{L}$ & Total nitrogen & na & na & na \\
\hline Gross-beta radioactivity & MCL-CA & 50 & $\mathrm{pCi} / \mathrm{L}$ & \multicolumn{4}{|c|}{ Organic constituents with benchmarks } \\
\hline Nickel & MCL-CA & 100 & $\mu \mathrm{g} / 1$ & Chlorobenzene & MCL-CA & 70 & $\mu \mathrm{g} / \mathrm{L}$ \\
\hline Nitrite & MCL-US & 1 & $\mathrm{mg} / \mathrm{L}$ & 1,1-Dichloroethane & MCL-CA & 5 & $\mu \mathrm{g} / \mathrm{L}$ \\
\hline Selenium & MSL-US & 50 & $\mu \mathrm{g} / 1$ & Methyl tert-butyl ether & MCL-CA & 13 & $\mu \mathrm{g} / \mathrm{L}$ \\
\hline Silver & HBSL & 100 & $\mu \mathrm{g} / 1$ & Perchloroethene & MCL-US & 5 & $\mu \mathrm{g} / \mathrm{L}$ \\
\hline Strontium & HBSL & 4,000 & $\mu \mathrm{g} / 1$ & Prometon & HBSL & 400 & $\mu \mathrm{g} / \mathrm{L}$ \\
\hline Thallium & MCL-US & 2 & $\mu \mathrm{g} / 1$ & Simazine & MCL-US & 4 & $\mu \mathrm{g} / \mathrm{L}$ \\
\hline Tritium & MCL-CA & 20,000 & $\mathrm{pCi} / \mathrm{L}$ & Styrene & MCL-US & 100 & $\mu \mathrm{g} / \mathrm{L}$ \\
\hline Uranium & MCL-US & 30 & $\mu \mathrm{g} / 1$ & Tetrachloromethane & MCL-CA & 0.5 & $\mu \mathrm{g} / \mathrm{L}$ \\
\hline$\delta^{2} \mathrm{H}$ in water & na & na & na & Diisopropyl ether & na & na & na \\
\hline$\delta^{18} \mathrm{O}$ in water & na & na & na & Fipronil sulfide & na & na & na \\
\hline Bromide & na & na & na & \multirow{3}{*}{\multicolumn{4}{|c|}{$\begin{array}{l}\text { 'The HAL-US is } 30 \mathrm{mg} / \mathrm{L} \text { "as ammonia." To facilitate comparison to the } \\
\text { analytical results, we have converted and reported this HAL-US as } 24.7 \mathrm{mg} / \mathrm{L} \\
\text { "as nitrogen." }\end{array}$}} \\
\hline Calcium & na & na & na & & & & \\
\hline Carbon-14 & na & na & na & & & & \\
\hline Cobalt & na & na & na & & & & \\
\hline
\end{tabular}




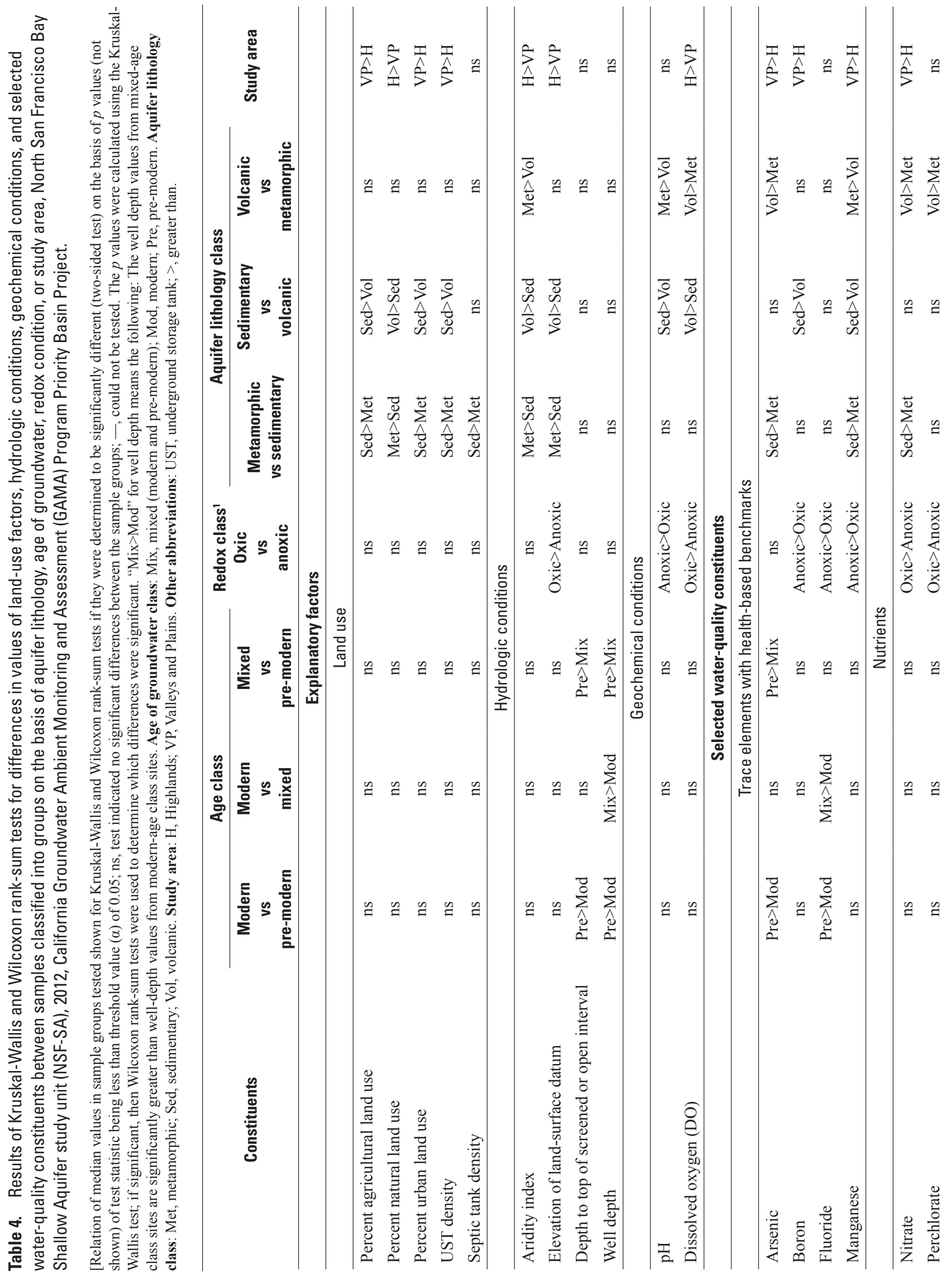




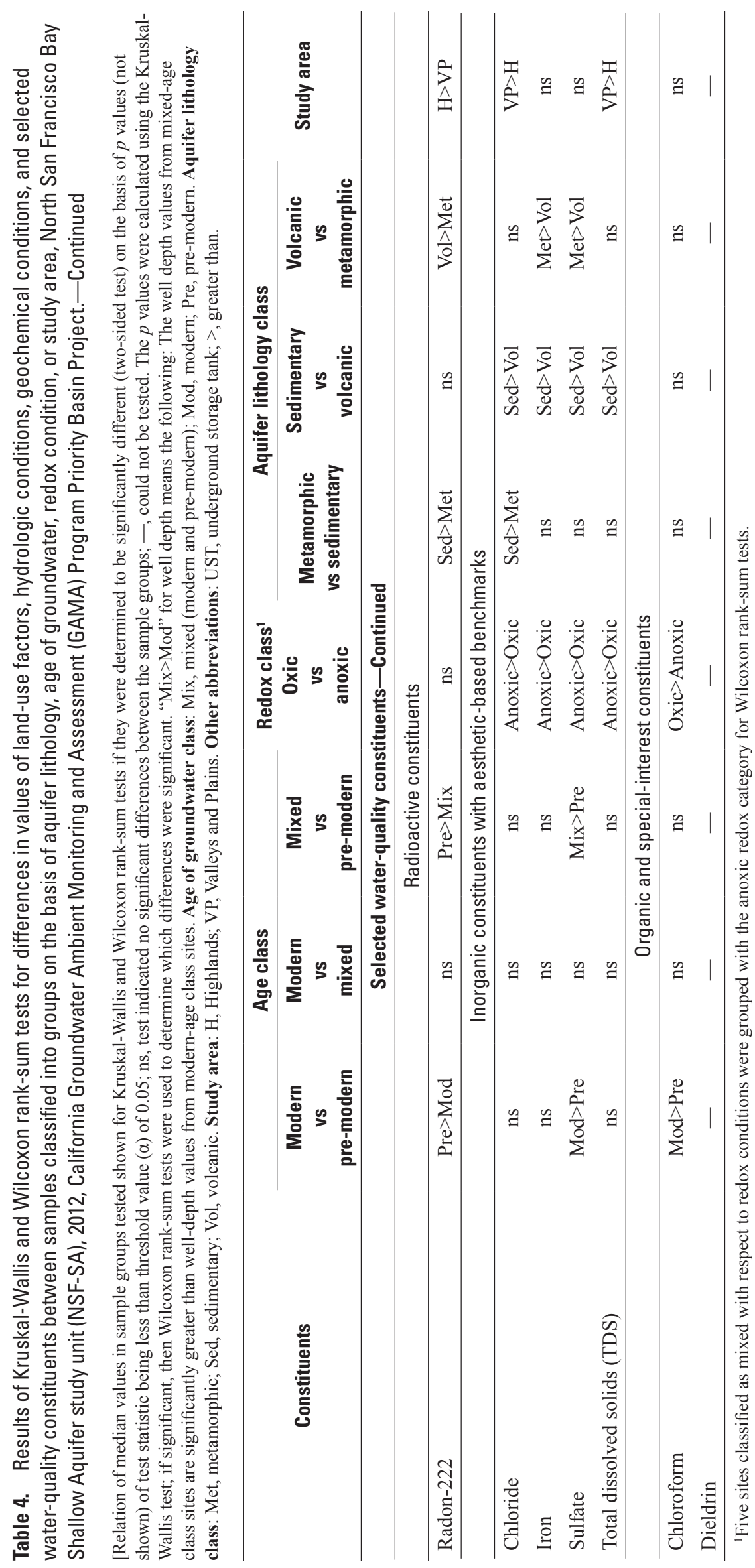




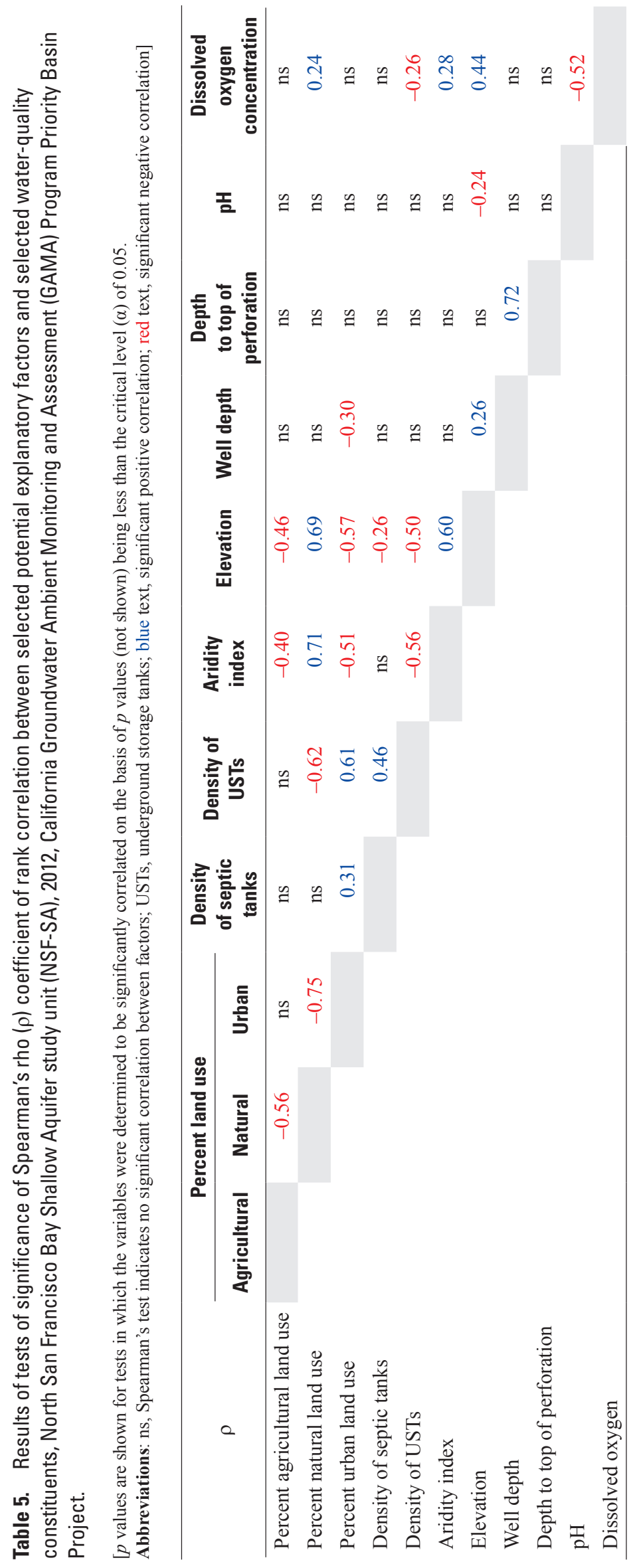


Table 6A. Summary of aquifer-scale proportions in the North San Francisco Bay Shallow Aquifer study unit (NSF-SA), 2012, California Groundwater Ambient Monitoring and Assessment (GAMA) Program Priority Basin Project for inorganic constituent classes with health-based and aesthetic-based benchmarks.

[Relative concentration categories: high, concentration of at least one constituent in group greater than water-quality benchmark; moderate, concentration of at least one constituent in group greater than 0.5 of benchmark and no constituents in group with concentration greater than benchmark; low, concentrations of all constituents in group is less than or equal to 0.5 of benchmark]

\begin{tabular}{lccc}
\hline \multirow{2}{*}{ Constituent class } & \multicolumn{3}{c}{$\begin{array}{c}\text { Aquifer-scale proportion } \\
\text { (percent) }\end{array}$} \\
\cline { 2 - 4 } & Low & Moderate & High \\
\hline \multicolumn{1}{c}{ Inorganic constituents with health-based benchmarks } \\
\hline Nutrients & 95 & 2.7 & 2.1 \\
Trace elements & 54 & 21 & 25 \\
$\begin{array}{l}\text { Any inorganic constituent with } \\
\text { health-based benchmarks }\end{array}$ & 52 & 21 & 27 \\
\hline$\quad$ Inorganic constituents with aesthetic-based benchmarks \\
\hline $\begin{array}{l}\text { Trace elements }{ }^{1} \\
\text { Major ions, and total dissolved } \\
\quad \text { solids }\end{array}$ & 75 & 4.8 & 20 \\
Any inorganic constituent with & 60 & 16 & 5.5 \\
$\quad$ aesthetic-based benchmarks & & 16 & 24 \\
\hline
\end{tabular}

${ }^{1}$ Iron is the only trace element in this category.
Table 6B. Summary of aquifer-scale proportions in the North San Francisco Bay Shallow Aquifer study unit (NSF-SA), 2012, California Groundwater Ambient Monitoring and Assessment (GAMA) Program Priority Basin Project for organic and specialinterest constituent classes with health-based benchmarks.

[Relative concentration categories: high, concentration of at least one constituent in group greater than water-quality benchmark; moderate, concentration of at least one constituent in group greater than 0.1 of benchmark and no constituents in group with concentration greater than benchmark; low, concentrations of all constituents in group is less than or equal to 0.1 of benchmark]

\begin{tabular}{|c|c|c|c|c|}
\hline \multirow{2}{*}{ Constituent class } & \multicolumn{4}{|c|}{$\begin{array}{l}\text { Aquifer-scale proportion } \\
\text { (percent) }\end{array}$} \\
\hline & $\begin{array}{c}\text { Not } \\
\text { detected }\end{array}$ & Low & Moderate & High \\
\hline \multicolumn{5}{|c|}{ Organic constituents with health-based benchmarks } \\
\hline Volatile organic compounds ${ }^{1}$ & 61 & 39 & 0 & 0 \\
\hline $\begin{array}{l}\text { Pesticides and pesticide } \\
\text { degradates }\end{array}$ & 88 & 11 & 0 & 1.0 \\
\hline Any organic constituent & 48 & 51 & 0 & 1.0 \\
\hline \multicolumn{5}{|c|}{ Special-interest constituent with health-based benchmark } \\
\hline Perchlorate & 73 & 24 & 2.7 & 0 \\
\hline $\begin{array}{l}{ }^{1} \text { One site had a high relative con } \\
\text { sult of surface contamination. A } \\
\text { or a long period of time. This dete } \\
\text { quifer proportions. }\end{array}$ & $\begin{array}{l}\text { tration of } \\
\text { had been } \\
\text { on was ex }\end{array}$ & $\begin{array}{l}\text { nzene } \\
\text { ked v }\end{array}$ & $\begin{array}{l}\text { which may } b \\
\text { ery near the } \mathrm{w} \\
\text { om calculatio }\end{array}$ & $\begin{array}{l}\text { the } \\
11 \text { hea } \\
\text { of }\end{array}$ \\
\hline
\end{tabular}




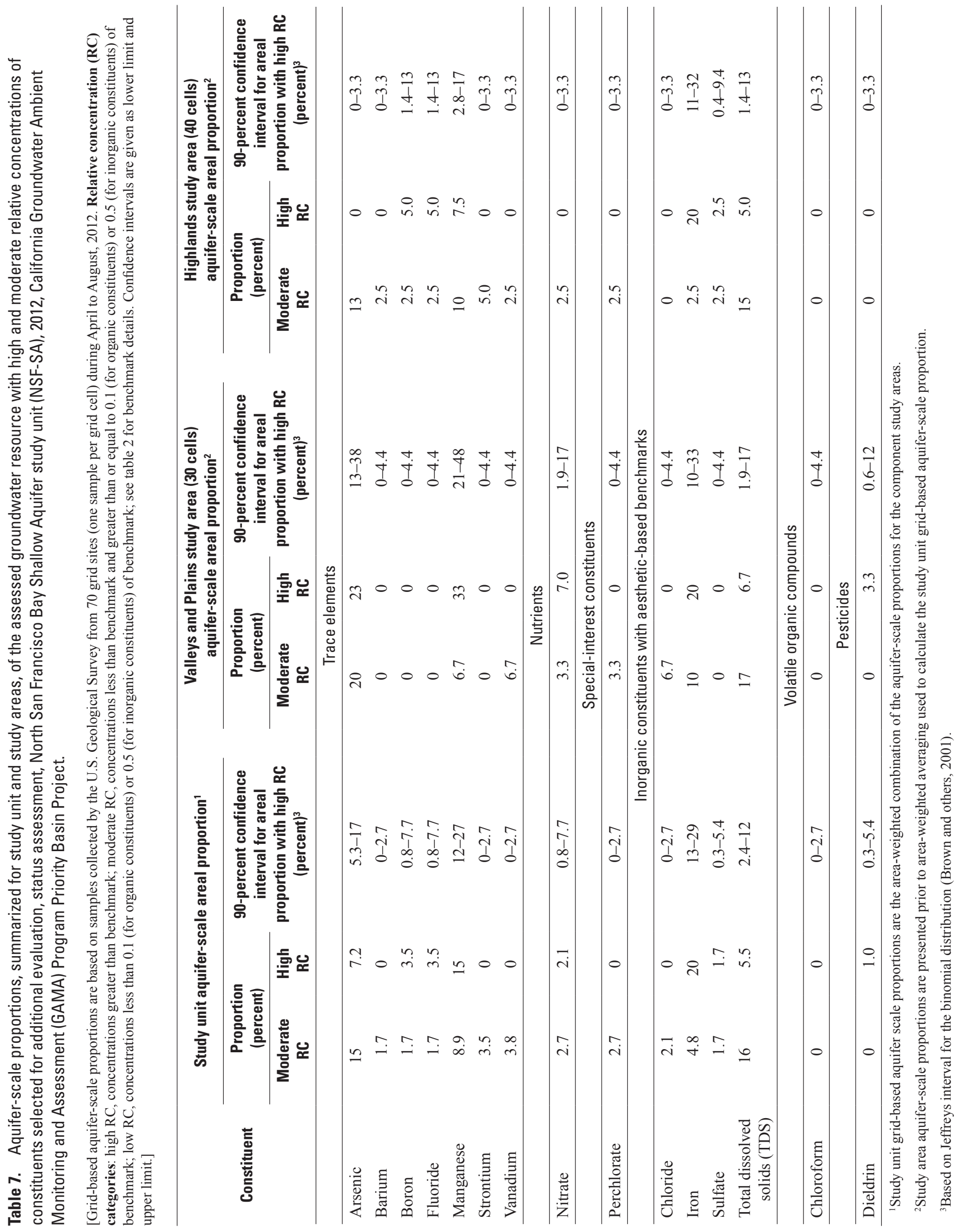


Table 8. Results from testing significance of Spearman's rho ( $\rho$ ) coefficient of rank-order correlations between selected potential explanatory factors and selected water-quality constituents, North San Francisco Bay Shallow Aquifer study unit (NSF-SA), 2012, California Groundwater Ambient Monitoring and Assessment (GAMA) Program Priority Basin Project.

[Tabled values of rho are shown for tests in which the variables were determined to be significantly correlated on the basis of $p$ value (not shown) of test being less than the critical level $(\alpha)$ of 0.05 . Abbreviations: ns, statistical test indicates no significant correlation between factors; blue text, significant positive correlation; red text, significant negative correlation; USTs, underground storage tanks;-—, no data]

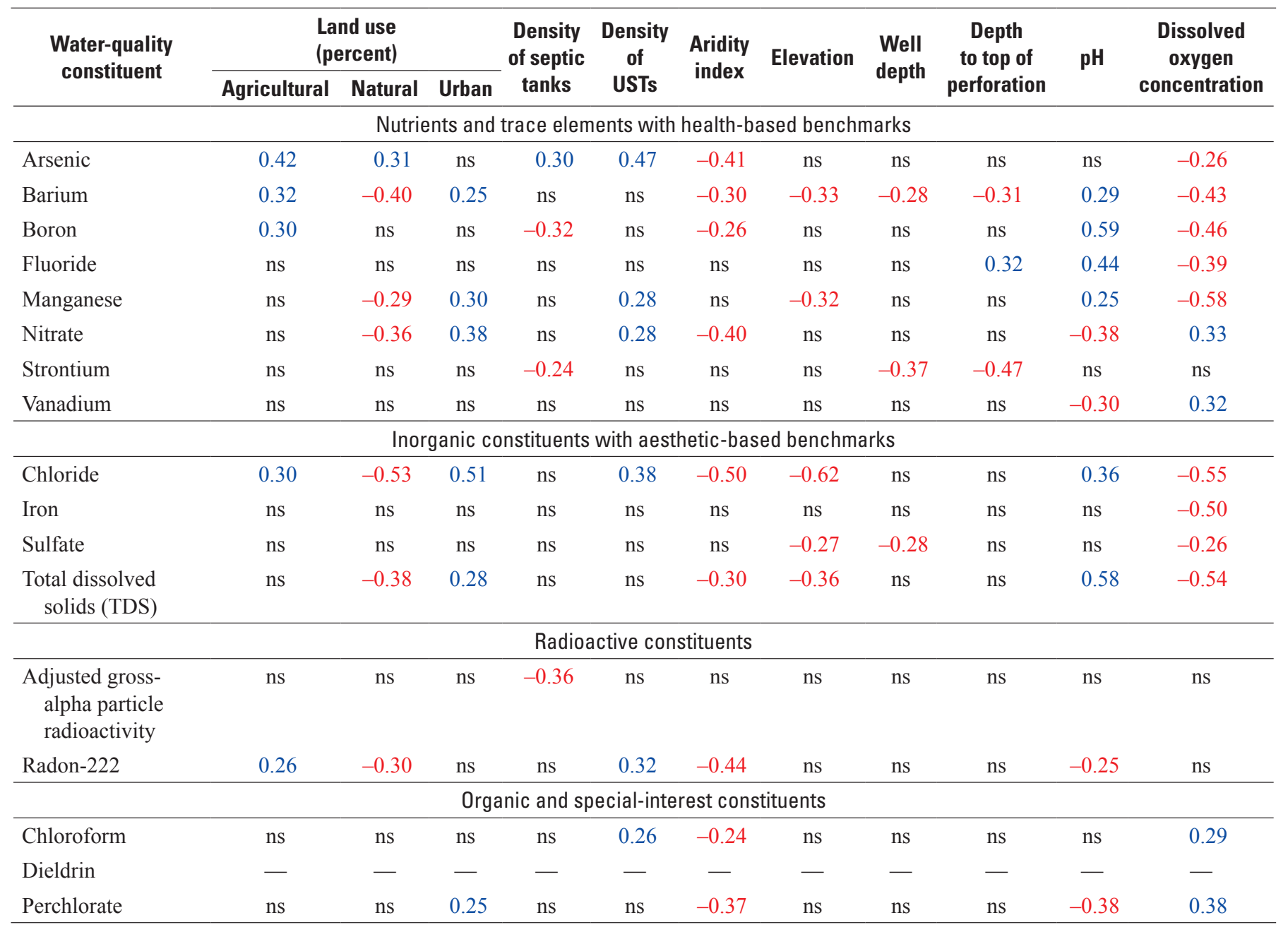




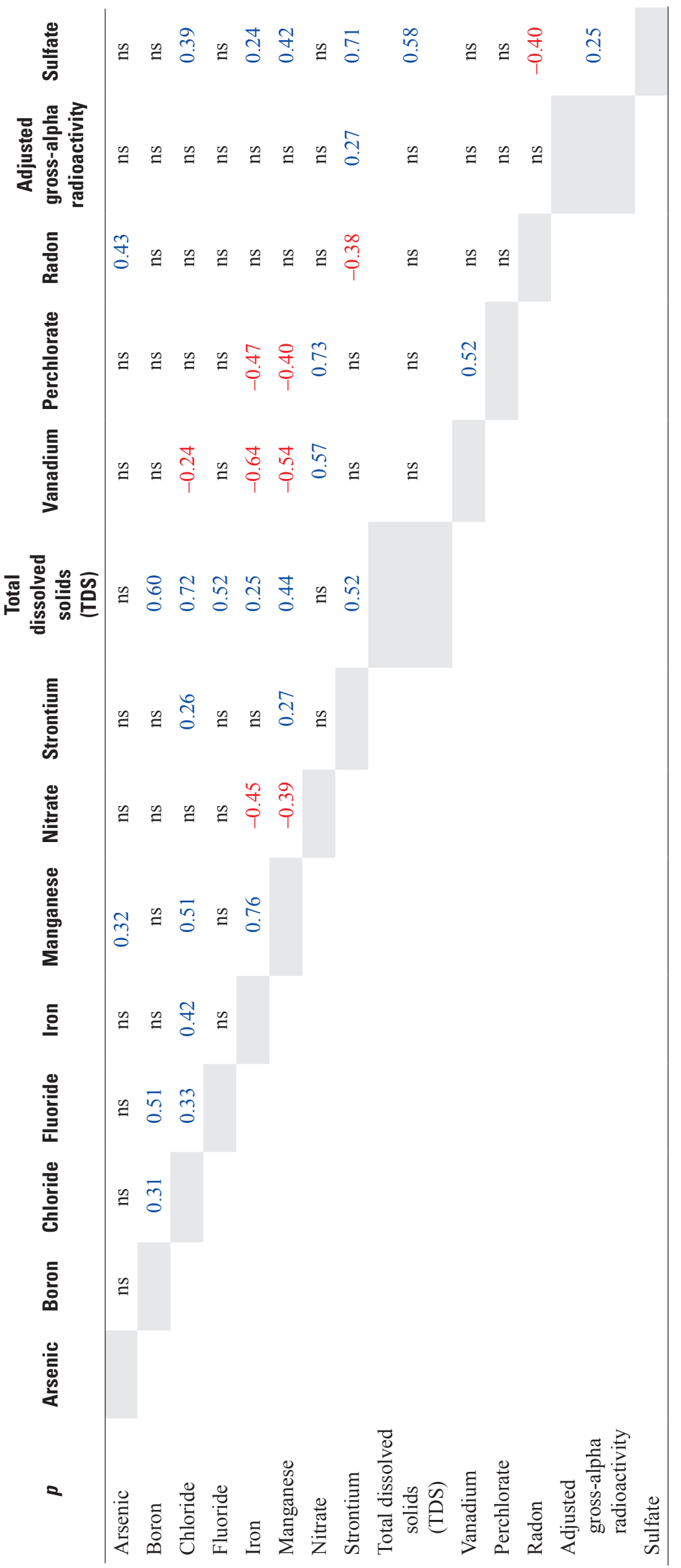




\section{Appendix 1. Attribution of Potential Explanatory Factors}

\section{Aquifer Lithology}

Aquifer lithology at the depth of the screened or open interval of each well was classified in three different categories on the basis of lithologic information from drillers' logs and from the California State geologic map (Jennings, 1977; Saucedo and others, 2000; appendix table 1-1). The State geologic map shows the lithologic unit exposed at the surface, which might not be the same as the lithologic unit at the depth range over which the well is screened or open. When both sources were available, the lithologic category estimated from the geologic map was compared to the lithology described in the driller's log. If the lithology from the map disagreed with the lithology from the driller's log, the category from the driller's log was used. If more than one type of lithology was intersected by the screened interval, we assigned the predominant category in the screened category. The three lithologic categories were the following:

Metamorphic rocks: includes rocks of the Franciscan Complex of late-Jurassic to Miocene age and Cretaceous marine deposits (California State geologic map units: KJf, $\mathrm{KJfm}, \mathrm{Kl}, \mathrm{Ku}, \mathrm{Mzv}$, and TK);

Volcanic rocks: Primarily rocks from the Cenozoic Era with some from the Mesozoic Era, these volcanics include pyroclastic flows and mudflows and the ultra-mafic rocks of Mesozoic age (California State geologic map units: Tv, Tvp, and um);

Sedimentary rocks: includes rocks deposited during the Cenozoic Era, such as Plio-Pleistocene marine and nonmarine deposits and Quaternary alluvium of marine and nonmarine origin (California State geologic map units: P, Q, and QPc).

\section{Land Use}

Land use was classified using the most recent national land cover product created by the Multi-Resolution Land Characteristics (MRLC) Consortium. The National Land Cover Database 2011 provides national land cover changes from 2001 to 2011 (Jin and others, 2013). This is an updated version of a dataset that has been used in previous national and regional studies relating land use to water quality (Gilliom and others, 2006; Zogorski and others, 2006). The dataset characterizes land cover during 2011 using Landsat satellite multispectral image data. The imagery was classified into 16 nationally consistent land-cover classes, which are fully described in Homer and others, 2004. For this study, these 16 land-cover classes were aggregated into three principal land-use classes adequate for the purpose of characterizing general land use: urban, agricultural, and natural. Overall land use (proportions of urban, agricultural, and natural) for the study unit and for buffer areas within a radius of 500 meters (m) surrounding each site (appendix table 1-1) was calculated using a geographic information system, ArcGIS (version 9.2; Johnson and Belitz, 2009).

\section{Underground Storage Tank and Septic Tank Densities}

Underground storage tank (UST) density in California was determined using a Thiessen polygon approach for spatial interpolation (Thiessen, 1911; Heywood and others, 1998; Tyler Johnson, U.S. Geological Survey, written commun., 2012), implemented using ArcGIS software and data from the SWRCB's GeoTracker database of environmental-cleanup sites (California State Water Resources Control Board, 2007).

Thiessen polygons were created by starting with the UST in the center of the polygon. The polygon edges were increased in all directions until they extended halfway to a neighboring UST (or they reach the edge of the State). The resultant statewide map of Thiessen polygons associates a uniquely shaped area of attribution for each UST. In most instances, there was only one UST per polygon, but occasionally there are multiple USTs. The total number of USTs per polygon was divided by the area of the polygon. This produced a density of USTs for each polygon. The NSF-SA groundwater sampling sites (grid sites) were then overlaid onto the Thiessen polygon map, and the grid site was assigned the UST density from the coincident Thiessen polygon (appendix table 1-1).

Septic tank density was determined from the 1990 Census of Population and Housing (U.S. Census Bureau, 1992). The mean density of septic tanks in each enumeration block of the housing census was calculated from the Census-reported number of tanks and block area. The density of septic tanks around each NSF-SA grid site was then calculated from the area-weighted mean of the block densities of all enumeration blocks intersecting a 500-m buffer around the site location (Tyler Johnson, U.S. Geological Survey, written commun., 2013; appendix table 1-1).

\section{Hydrologic Conditions}

Some of the hydrologic conditions at each site were represented by elevation and an aridity index. The aridity index is defined by the United Nations Environment Programme (1997) and United Nations Educational, Scientific, and Cultural Organization (1979) as follows:

$$
\text { aridity index }=\frac{\text { average annual precipitation }}{\text { average annual evapotranspiration }}(1-1)
$$


Greater values of the index correspond to wetter conditions. Index values less than 0.05 are defined as hyperarid, $0.05-0.20$ as arid, $0.20-0.50$ as semiarid, 0.50 0.65 as dry subhumid, $0.65-1.00$ as humid, and greater than 1.00 as wet (United Nations Educational, Scientific, and Cultural Organization, 1979; United Nations Environment Programme 1997). Average annual precipitation for each site was coincident with that in the GIS map data for average annual precipitation from 1971-2000 (PRISM Climate Group, 2007). Average annual evapotranspiration for each site was extracted as a simple point estimate from an ESRI ${ }^{\circledR}$ ArcGIS dataset modified from Flint and Flint (2007). The modification consisted of calibrating the modeled evapotranspiration values to the measured California Irrigation Management Information System reference evapotranspiration values (California Irrigation Management Information System, 2005; Alan Flint, U.S. Geological Survey, oral commun., 2009). Calculated aridity-index values are listed in appendix table 1-1.

The range of site land-surface elevations was large, ranging from the minimum of $12 \mathrm{~m}$ to a maximum $570 \mathrm{~m}$. Land-surface elevations were obtained from the U.S. Geological Survey (2006) National Elevation Dataset and are reported in feet relative to NAVD 88 (appendix table 1-1).

\section{Well Construction}

Well construction data primarily were obtained from drillers' logs filed with CDWR. In some cases, well construction data were obtained from ancillary records of site owners or the USGS National Water Information System database. Well depths and depths to the tops and bottoms of the screened or open intervals for wells sampled by USGSGAMA are listed in appendix table 1-2. Wells drilled in hard rock commonly do not have casings; the borehole is left open. For these wells, the top of the screened or open interval was defined as the base of the sanitary seal, and the bottom was defined as the depth of the borehole. Springs were assigned a value of "at LSD" for the site depth and depths to top and bottom of the screened interval. Sites were classified as production wells or springs (appendix table 1-2), because no monitoring wells were sampled.

\section{Groundwater Age}

Groundwater dating techniques indicate the time since the groundwater was recharged into the aquifer system. Data for the age-dating tracers tritium $\left({ }^{3} \mathrm{H}\right)$ and carbon- $14\left({ }^{14} \mathrm{C}\right)$ were used to classify groundwater ages into three categories: modern, mixed, and pre-modern.

Tritium is a short-lived radioactive isotope of hydrogen with a half-life of 12.32 years (Lucas and Unterweger, 2000). Tritium is produced naturally in the atmosphere from the interaction of cosmogenic radiation with nitrogen (Craig and Lal, 1961) and anthropogenically by aboveground nuclear explosions and the operation of nuclear reactors. Tritium enters the hydrological cycle following oxidation to tritiated water. Aboveground nuclear explosions resulted in a large increase in the tritium concentration in precipitation, beginning in about 1952 and peaking in 1963 at tritium-activity values exceeding 1,000 tritium units (TU) in the northern hemisphere (Michel, 1989). Tritium activity in precipitation under natural conditions in the NSF-SA in 1952 most likely was about 2-4 TU (Bryant Jurgens, U.S. Geological Survey, oral commun., 2014). On the west coast, most of the storms are oceanic in origin, so the precipitated water from these storms originates mostly from exchange with surface ocean water, which has relatively low tritium activities (Michel, 1989). Radioactive decay for a period of 60 years (1952-2012) would decrease initial tritium values of $2-4$ TU to $0.1-0.2 \mathrm{TU}$; therefore, groundwater in samples collected for the NSF-SA in 2012 with tritium activity less than $0.2 \mathrm{TU}$ was interpreted to have recharged the shallow aquifer primarily before 1952 .

Based on an estimated tritium input curve, the minimum tritium activity in 2012 for groundwater recharged between 1952 and 2012 would be approximately 1 TU (Bryant Jurgens, U.S. Geological Survey, oral commun., 2014). Groundwater with tritium activity between 0.2 and 1 TU was inferred to represent a mixture of waters recharged before and after 1952. Tritium values greater than $1 \mathrm{TU}$ can indicate either groundwater that was entirely recharged after 1952 or groundwater that is a mixture of waters recharged before and after 1952.

Dissolved inorganic carbon species, carbonic acid, bicarbonate, and carbonate typically are used for ${ }^{14} \mathrm{C}$ dating of groundwater. Carbon-14 is formed in the atmosphere by the interaction of cosmic-ray neutrons with nitrogen atoms and, to a lesser degree, with oxygen and carbon. ${ }^{14} \mathrm{C}$ atoms become incorporated into carbon dioxide and mixed throughout the atmosphere. The carbon dioxide enters the hydrologic cycle because it dissolves in precipitation and surface water in contact with the atmosphere. The ${ }^{14} \mathrm{C}$ content of groundwater reflects the duration of radioactive decay since groundwater was last exposed to the atmospheric ${ }^{14} \mathrm{C}$ source. ${ }^{14} \mathrm{C}$ has a halflife of 5,730 years and can be used to estimate groundwater ages ranging from 1,000 to approximately 30,000 years before present.

The ${ }^{14} \mathrm{C}$ data may be reported as percent modern (pM) or as percent modern carbon $(\mathrm{pmC})$. The ${ }^{14} \mathrm{C}$ data for the NSF-SA in Bennett and Fram (2014) are given in pM units as reported by the analyzing laboratory. The ${ }^{14} \mathrm{C}$ data in $\mathrm{pM}$ units have been normalized for carbon isotopic fractionation based on a $\delta^{13} \mathrm{C}$ value of -25 per mil. The un-normalized ${ }^{14} \mathrm{C}$ data in $\mathrm{pmC}$ units are used in this report. Values of pmC greater than 100 percent are possible because atmospheric nuclear testing between the 1940s and 1960s increased ${ }^{14} \mathrm{C}$ concentrations above natural background levels. Data were converted from $\mathrm{pM}$ to $\mathrm{pmC}$ using following equation derived from Plummer and others (2004): 


$$
p m C=\frac{p M\left(1+\frac{{ }^{\delta 13} C}{1,000}\right)^{2}}{0.975^{2}}
$$

where

$$
\begin{aligned}
& \text { pmC is percent modern carbon; } \\
& p M \quad \text { is the }{ }^{14} \mathrm{C} \text { value in units of normalized percent } \\
& \text { modern carbon; and } \\
& \delta^{13} C \quad \text { is the measured enrichment with or depletion } \\
& \text { of }{ }^{13} \mathrm{C} \text {, in units per mil, in the sample's } \\
& \text { isotopic composition relative to the } \\
& \text { standard. }
\end{aligned}
$$

In this report, groundwater samples with ${ }^{14} \mathrm{C}$ values less than or equal to $88 \mathrm{pmC}$ were defined as "pre-modern," because the highest ${ }^{14} \mathrm{C}$ value in NSF-PA and NSF-SA samples with tritium less than 0.2 TU was $88 \mathrm{pmC}$. Based on an estimated ${ }^{14} \mathrm{C}$ input curve, the minimum ${ }^{14} \mathrm{C}$ of groundwater recharged between 1952 and 2012 was estimated as 99 pmC. Samples with ${ }^{14} \mathrm{C}$ between 88 and $99 \mathrm{pmC}$ are interpreted to include water of mixed age classes, and samples with ${ }^{14} \mathrm{C}$ greater than 99 could either be mixed or modern water. Although more sophisticated lumped parameter models used for analyzing age distributions of groundwater that incorporate mixing are available (for example, Cook and Böhlke, 2000; Jurgens and others, 2012), use of these alternative models to characterize age mixtures was beyond the scope of this report. Rather, classification into modern (recharged after 1952), mixed, and pre-modern (recharged before 1952) age categories was sufficient to provide an appropriate and useful characterization for the purposes of examining groundwater quality. Tritium concentration, percent modern carbon, and groundwater age classification are reported for each NSF-SA sample in appendix table 1-3.

\section{Geochemical Condition}

Geochemical conditions were described by oxidationreduction (redox) characteristics and $\mathrm{pH}$. Redox conditions influence the mobility of many organic and inorganic constituents (McMahon and Chapelle, 2008). Along groundwater flow paths, redox conditions commonly proceed along a well-documented sequence of terminal electron acceptor processes (TEAP); one TEAP typically dominates at a particular time and aquifer location (Chapelle and others, 1995; Chapelle, 2001). The predominant TEAPs are oxygen-reduction, nitrate-reduction, manganese-reduction, iron-reduction, sulfate-reduction, and methanogenesis. Groundwater samples can contain chemical species that indicate more than one TEAP. Evidence for more than one TEAP can indicate mixing of waters from different redox zones upgradient of the site, a site that is screened across more than one redox zone, or spatial variability in microbial activity in the aquifer.

In this report, oxidation-reduction conditions were represented in two ways: by dissolved oxygen (DO) concentrations and by redox class (appendix table 1-4). Dissolved oxygen concentrations were measured in the field at all NSF-SA wells (Bennett and Fram, 2014). Redox conditions were classified on the basis of DO, nitrate, manganese, and iron concentrations using a modified version of the classification scheme of McMahon and Chapelle (2008) and Jurgens and others (2009). The modification was that the DO threshold for separating oxic from anoxic groundwater was increased from 0.5 to $1 \mathrm{mg} / \mathrm{L}$. Anoxic conditions were further classified as suboxic, nitrate-reducing, manganese reducing, or iron-reducing. Samples were classified as mixed if DO concentration was greater than or equal to $1 \mathrm{mg} / \mathrm{L}$ and the manganese or iron concentrations were greater than the thresholds for indicating manganese-reducing or iron-reducing conditions (appendix table 1-5).

\section{References Cited}

Bennett, G.L., V, and Fram, M.S., 2014, Groundwater-quality data in the North San Francisco Bay Shallow Aquifer study unit, 2012-Results from the California GAMA Program:

U.S. Geological Survey Data Series 865, 94 p., http://pubs.usgs.gov/ds/0865/.

California Irrigation Management Information System, 2005, CIMIS reference evapotranspiration zones: California Irrigation Management Information System website, accessed July 2, 2014, at http://wwwcimis.water.ca.gov/ App_Themes/images/etozonemap.jpg.

California State Water Resources Control Board, 2007, GeoTracker: Cleanup sites download, accessed November 2007, at https://geotracker.waterboards.ca.gov/.

Chapelle, F.H., 2001, Groundwater microbiology and geochemistry ( $2 \mathrm{~d}$ ed.): New York, John Wiley and Sons, Inc., $477 \mathrm{p}$.

Chapelle, F.H., McMahon, P.B., Dubrovsky, N.M., Fujii, R.F., Oaksford, E.T., and Vroblesky, D.A., 1995, Deducing the distribution of terminal electron-accepting processes in hydrologically diverse groundwater systems: Water Resources Research, v. 31, no. 2, p. 359-371, http://dx.doi.org/10.1029/94WR02525.

Chin, Mian, and Davis, D.D., 1993, Global sources and sinks of OCS and $\mathrm{CS}_{2}$ and their distributions: Global Biogeochemical Cycles, v. 7, no. 2, p. 321-337, http://dx.doi.org/10.1029/93GB00568. 
Cook, P.G., and Böhlke, J.K., 2000, Determining timescales for groundwater flow and solute transport, in Cook, P.G., and Herczeg, A., eds., Environmental tracers in subsurface hydrology: Boston, Kluwer Academic Publishers, p. 1-30.

Craig, Harmon, and Lal, Devendra, 1961, The production rate of natural tritium: Tellus, v. 13, no. 1, p. 85-105, http://onlinelibrary.wiley.com/ doi/10.1111/j.2153-3490.1961.tb00068.x/full.

Flint, L.E., and Flint, A.L., 2007, Regional analysis of groundwater recharge, in Stonestrom, D.A., Constantz, Jim, Ferre, T.P.A., and Leake, S.A., eds., Ground-water recharge in the arid and semiarid southwestern United States: U.S. Geological Survey Professional Paper 1703-B, p. 29-60, http://pubs.usgs.gov/pp/pp1703/b/.

Gilliom, R.J., Barbash, J.E., Crawford, C.G., Hamilton, P.A., Martin, J.D., Nakagaki, Naomi, Nowell, L.H., Scott, J.C., Stackelberg, P.E., Thelin, G.P., and Wolock, D.M., 2006, The quality of our nation's waters - Pesticides in the nation's streams and ground water, 1992-2001: U.S. Geological Survey Circular 1291, 172 p., http:/pubs.usgs.gov/circ/2005/1291/.

Heywood, Ian, Cornelius, Sarah, Carver, Steve, 1998, An introduction to geographical information systems: New Jersey, Prentice Hall, 278 p.

Homer, C.G., Huang, Chengquan, Yang, Limin, Wylie, B.K., and Coan, Michael, 2004, Development of a 2001 national land cover database for the United States: Photogrammetric Engineering and Remote Sensing, v. 70, no. 7, p. 829-840, https://doi.org/10.14358/PERS.70.7.829.

Jennings, C.W., 1977, Geologic map of California: California Department of Conservation, Division of Mines and Geology Geologic data map no. 2, scale 1:750,000, http:// www.quake.ca.gov/gmaps/GMC/stategeologicmap.html.

Jin, Suming, Yang, Limin, Danielson, Patrick, Homer, Collin, Fry, Joyce, and Xian, George, 2013, A comprehensive change detection method for updating the National Land Cover Database to circa 2011: Remote Sensing of Environment, v. 132, p. 159-175, https://www.mrlc.gov/ downloadfile2.php?file=Preferred_NLCD11_citation.pdf.

Johnson, T.D., and Belitz, Kenneth, 2009, Assigning land use to supply wells for the statistical characterization of regional groundwater quality - Correlating urban land use and VOC occurrence: Journal of Hydrology, v. 370, p. 100-108, http://ca.water.usgs.gov/projects/gama/pdfs/ Johnson_2009_1-s2.0-S0022169409001462-main.pdf.

Jurgens, B.C., McMahon, P.B., Chapelle, F.H., and Eberts, S.M., 2009, An Excel ${ }^{\circledR}$ workbook for identifying redox processes in ground water: U.S. Geological Survey Open-File Report 2009-1004, 8 p., http://pubs.usgs.gov/of/2009/1004/.
Jurgens, B.C., Böhlke, J.K., and Eberts, S.M., 2012, TracerLPM (version1)-An Excel ${ }^{\circledR}$ workbook for interpreting groundwater age distributions from environmental tracer data: U.S. Geological Survey Techniques and Methods Report 4-F3, 60 p., http://pubs.usgs.gov/tm/4-f3/.

Lucas, L.L., and Unterweger, M.P., 2000, Comprehensive review and critical evaluation of the half-life of tritium: Journal of Research of the National Institute of Standards and Technology, v. 105, no. 4, p. 541-549, http://dx.doi.org/10.6028/jres.105.043.

McMahon, P.B., and Chapelle, F.H., 2008, Redox processes and water quality of selected principal aquifer systems: Ground Water, v. 46, no. 2, p. 29-271.

Michel, R.L., 1989, Tritium deposition in the continental United States, 1953-83: U.S. Geological Survey WaterResources Investigations Report 89-4072, 46 p., http://pubs.er.usgs.gov/publication/wri894072.

Plummer, L.N., Bexfield, L.M., Anderholm, S.K., Sanford, W.E., and Busenberg, Eurybiades, 2004, Geochemical characterization of ground-water flow in the Santa Fe Group aquifer system, Middle Rio Grande Basin, New Mexico: U.S. Geological Survey Water-Resources Investigations Report 03-4131, 395 p., http://pubs.usgs.gov/wri/wri034131/.

PRISM Climate Group, 2007, United States average annual precipitation, maximum and minimum temperature, 19712000: Oregon State University, PRISM Climate Group website, accessed October 11, 2012, at http://prism.oregonstate.edu/.

Saucedo, G.J., Bedford, D.R., Raines, G.L., Miller, R.J., and Wentworth, C.M., 2000, GIS data for the geologic map of California (version 2.0): California Department of Conservation, Division of Mines and Geology, CD-ROM 2000-007.

Thiessen, A.H., 1911, Precipitation averages for large areas: Monthly Weather Review, v. 39, p. 1082-1084, http://dx.doi.org/10.1175/1520-0493(1911)39\%3C1082b:PA FLA\%3E2.0.CO;2.

United Nations Educational, Scientific, and Cultural Organization (UNESCO), 1979, Map of the world distribution of arid regions - Explanatory note: Man and the Biosphere (MAB) Technical Notes, Paris, v. 7, 42 p.

United Nations Environment Programme, 1997, World atlas of desertification, 2d ed.: London, Edward Arnold, 182 p.

U.S. Census Bureau, 1992, Census of population and housing, 1990-Summary tape file 3A: Washington, D.C., U.S. Census Bureau, machine-readable data, accessed May 19, 2015, at ftp://ftp2.census.gov/census_1990/. 
U.S. Geological Survey, 2006, National Elevation Dataset (NED): U.S. Geological Survey database, accessed at http://ned.usgs.gov.

Zogorski, J.S., Carter, J.M., Ivahnenko, Tamara, Lapham, W.W., Moran, M.J., Rowe, B.L., Squillace, P.J., and Toccalino, P.L., 2006, Volatile organic compounds in the Nation's ground water and drinking-water supply wells: U.S. Geological Survey Circular 1292, 101 p., http://pubs.usgs.gov/circ/circ1292/. 
Table 1-1. Site-specific data for aquifer lithology class, land use, hydrologic conditions, underground storage tank (UST) density, and septic tank density, North San Francisco Bay Shallow Aquifer study unit (NSF-SA), 2012, California Groundwater Ambient Monitoring and Assessment (GAMA) Program Priority Basin Project.

[GAMA site identification numbers: S-NSF-H, North San Francisco Bay Shallow Aquifer study unit Highlands study area site; S-NSF-HU, North San Francisco Bay Shallow Aquifer study unit Highlands study area extra site; S-NSF-VP, North San Francisco Bay Shallow Aquifer study unit Valleys and Plains study area site. Abbreviations: ft, feet; LSD, land-surface datum; m, meter; na, not available; tanks $/ \mathrm{km}^{2}$, tanks per square kilometer; USGS, U.S. Geological Survey; *, site is not included in the comparison of the public-supply and shallow aquifer systems]

\begin{tabular}{|c|c|c|c|c|c|c|c|c|}
\hline $\begin{array}{c}\text { USGS } \\
\text { GAMA site } \\
\text { identification } \\
\text { number }\end{array}$ & $\begin{array}{l}\text { Aquifer } \\
\text { lithology } \\
\text { class }\end{array}$ & \multicolumn{3}{|c|}{ Land use within $500 \mathrm{~m}$ of site ${ }^{1}$} & $\begin{array}{c}\text { UST } \\
\text { density } \\
(\operatorname{tanks/km²)}\end{array}$ & $\begin{array}{c}\text { Septic tank } \\
\text { density }^{5} \\
\left(\operatorname{tanks} / \mathbf{k m}^{2}\right)\end{array}$ & \multicolumn{2}{|c|}{ Hydrologic conditions } \\
\hline S-NSF-H01* & Metamorphic & 0 & 93 & 7 & 0.06 & 30.75 & 1.27 & 1,073 \\
\hline S-NSF-H02* & Metamorphic & 0 & 83 & 17 & 0.04 & 10.45 & 1.20 & 65 \\
\hline S-NSF-H05* & Metamorphic & 0 & 96 & 4 & 0.03 & 1.82 & 1.08 & 1,150 \\
\hline S-NSF-H06* & Metamorphic & 0 & 94 & 6 & 0.01 & 0.52 & 1.14 & 1,254 \\
\hline S-NSF-H07* & Volcanic & 0 & 100 & 0 & 0.01 & 0.52 & 0.98 & 1,144 \\
\hline S-NSF-H08* & Metamorphic & 0 & 91 & 9 & 0.03 & 1.38 & 0.97 & 1,781 \\
\hline S-NSF-H12* & Metamorphic & 0 & 95 & 5 & 0.11 & 10.96 & 1.09 & 710 \\
\hline S-NSF-H13 & Sedimentary & 0 & 97 & 3 & 0.04 & 1.79 & 0.86 & 77 \\
\hline S-NSF-H14 & Sedimentary & 0 & 59 & 41 & 0.03 & 1.85 & 0.83 & 90 \\
\hline S-NSF-H15 & Sedimentary & 5 & 87 & 8 & 0.06 & 5.40 & 0.91 & 99 \\
\hline S-NSF-H16 & Sedimentary & 0 & 92 & 8 & 0.22 & 20.43 & 0.91 & 231 \\
\hline S-NSF-H17 & Sedimentary & 0 & 84 & 16 & 0.09 & 37.50 & 1.00 & 232 \\
\hline S-NSF-H18 & Sedimentary & 0 & 15 & 85 & 0.81 & 19.83 & 0.85 & 111 \\
\hline S-NSF-H19* & Metamorphic & 18 & 70 & 12 & 0.05 & 1.30 & 0.89 & 315 \\
\hline S-NSF-H20* & Metamorphic & 0 & 100 & 0 & 0.01 & 1.38 & 0.90 & 1,872 \\
\hline S-NSF-H21 & Metamorphic & 7 & 88 & 5 & 0.02 & 1.22 & 0.81 & 490 \\
\hline S-NSF-H28 & Sedimentary & 0 & 47 & 53 & 0.22 & 7.60 & 0.70 & 263 \\
\hline S-NSF-H29 & Volcanic & 0 & 89 & 11 & 0.04 & 4.95 & 0.92 & 1,022 \\
\hline S-NSF-H30 & Volcanic & 0 & 90 & 10 & 0.04 & 4.95 & 0.83 & 672 \\
\hline S-NSF-H31* & Metamorphic & 0 & 100 & 0 & 0.06 & 4.22 & 0.91 & 1,099 \\
\hline S-NSF-H32 & Volcanic & 9 & 91 & 0 & 0.09 & 8.25 & 1.05 & 1,125 \\
\hline S-NSF-H33 & Volcanic & 5 & 86 & 9 & 2.36 & 8.25 & 0.94 & 803 \\
\hline S-NSF-H34* & Sedimentary & 0 & 92 & 8 & 0.05 & 1.96 & 0.79 & 371 \\
\hline S-NSF-H35 & Sedimentary & 40 & 48 & 13 & 0.02 & 5.86 & 0.70 & 175 \\
\hline S-NSF-H36 & Volcanic & 0 & 95 & 5 & 0.03 & 2.61 & 0.68 & 1,264 \\
\hline S-NSF-H37 & Volcanic & 0 & 94 & 6 & 0.04 & 3.00 & 0.69 & 1,230 \\
\hline S-NSF-H38* & Metamorphic & 0 & 93 & 7 & 0.03 & 3.92 & 0.94 & 648 \\
\hline S-NSF-H39 & Volcanic & 0 & 97 & 3 & 0.16 & 3.90 & 0.72 & 582 \\
\hline
\end{tabular}


Table 1-1. Site-specific data for aquifer lithology class, land use, hydrologic conditions, underground storage tank (UST) density, and septic tank density, North San Francisco Bay Shallow Aquifer study unit (NSF-SA), 2012, California Groundwater Ambient Monitoring and Assessment (GAMA) Program Priority Basin Project.

[GAMA site identification numbers: S-NSF-H, North San Francisco Bay Shallow Aquifer study unit Highlands study area site; S-NSF-HU, North San Francisco Bay Shallow Aquifer study unit Highlands study area extra site; S-NSF-VP, North San Francisco Bay Shallow Aquifer study unit Valleys and Plains study area site. Abbreviations: ft, feet; LSD, land-surface datum; $\mathrm{m}$, meter; na, not available; tanks $/ \mathrm{km}^{2}$, tanks per square kilometer; USGS, U.S. Geological Survey; *, site is not included in the comparison of the public-supply and shallow aquifer systems]

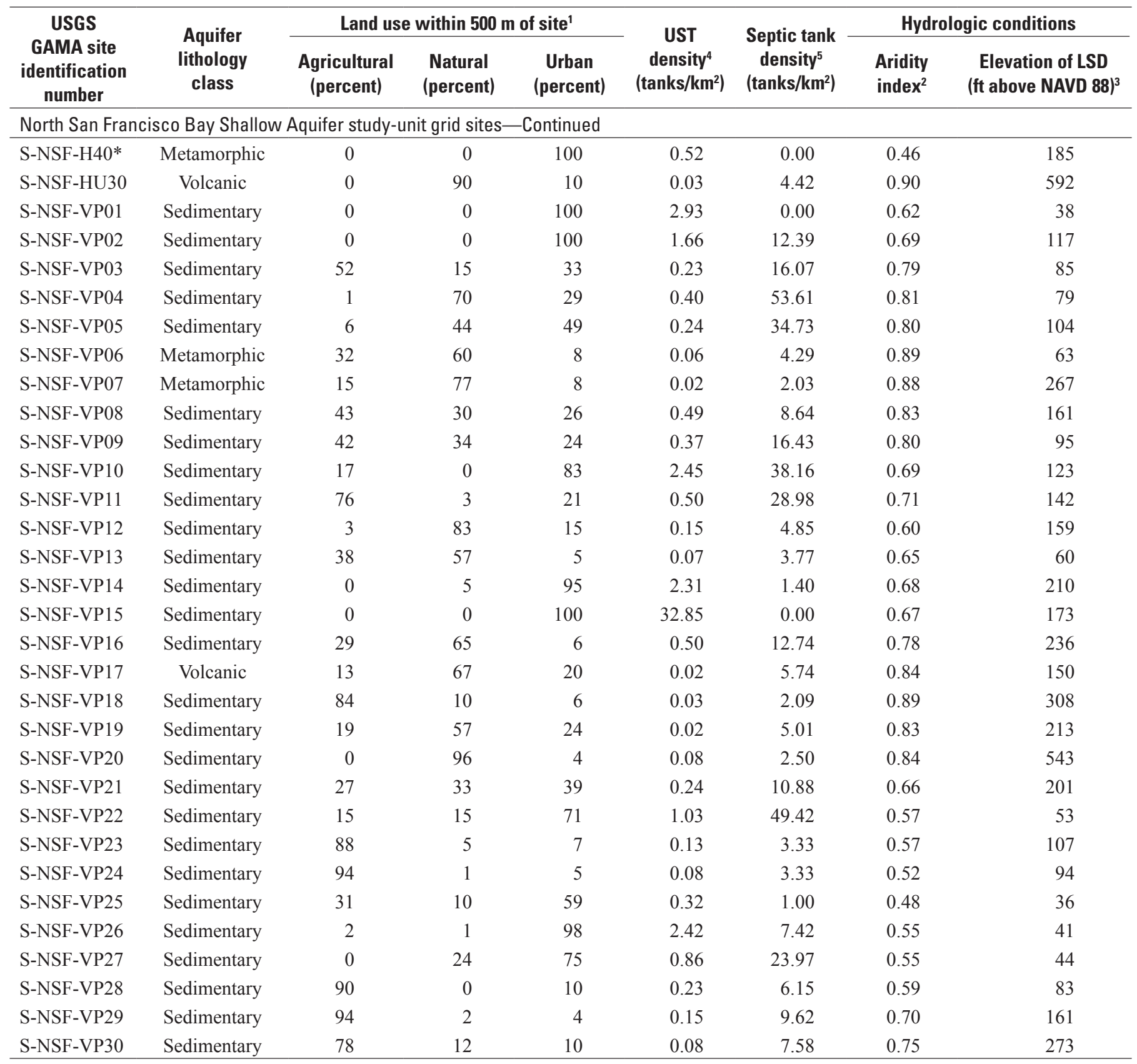

${ }^{1}$ Land-use percentages within 500-m radius of sampled site (Johnson and Belitz, 2009; Jin and others, 2013).

${ }^{2}$ Aridity index is average annual precipitation divided by average annual evapotranspiration (United Nations Educational, Scientific, and Cultural Organization, 1979).

${ }^{3}$ Land-surface datum (LSD) is a datum plane that is approximately at land surface at each site. The elevation of the LSD is described in feet above the North American Vertical Datum 1988 (NAVD 88).

${ }^{4}$ Leaking (or formerly leaking) underground fuel tank density within 500-m radius of sampled site (California Environmental Protection Agency, 2001).

${ }^{5}$ Septic tank density within 500-m radius of sampled site (U.S. Census Bureau, 1990). 
Table 1-2. Site construction information for U.S. Geological Survey sampled grid sites and extra site, North San Francisco Bay Shallow Aquifer study unit (NSF-SA), 2012, California Groundwater Ambient Monitoring and Assessment (GAMA) Program Priority Basin Project.

[GAMA site identification number: S-NSF-H, North San Francisco Bay Shallow Aquifer study unit, Highlands study area site; S-NSF-HU, North San Francisco Bay Shallow Aquifer study unit, Highlands study area extra site; S-NSF-VP, North San Francisco Bay Shallow Aquifer study unit, Valleys and Plains study area site. Other abbreviations: $\mathrm{ft}$, feet; LSD, land-surface datum; na, not available]

\begin{tabular}{|c|c|c|c|c|}
\hline \multirow{2}{*}{$\begin{array}{l}\text { USGS GAMA site } \\
\text { identification number }\end{array}$} & \multicolumn{3}{|c|}{$\begin{array}{c}\text { Site construction information } \\
\text { (ft below LSD') }\end{array}$} & \multirow{2}{*}{ Site type ${ }^{2}$} \\
\hline & $\begin{array}{c}\text { Site depth } \\
\text { (ft below LSD) }\end{array}$ & $\begin{array}{c}\text { Top of screened or open interval } \\
\text { (ft below LSD) }\end{array}$ & $\begin{array}{l}\text { Bottom of screened or open interval } \\
\text { (ft below LSD) }\end{array}$ & \\
\hline \multicolumn{5}{|c|}{ North San Francisco Bay Shallow Aquifer study-unit grid sites } \\
\hline S-NSF-H01 & 80 & na & na & Production \\
\hline S-NSF-H02 & 30 & 11 & 30 & Production \\
\hline S-NSF-H04 & 240 & 80 & 240 & Production \\
\hline S-NSF-H05 & 160 & 60 & 160 & Production \\
\hline S-NSF-H06 & na & na & na & Production \\
\hline S-NSF-H07 & 200 & 60 & 200 & Production \\
\hline S-NSF-H11 & 22 & 11 & 22 & Production \\
\hline S-NSF-H12 & at LSD & at LSD & at LSD & Spring \\
\hline S-NSF-H13 & na & na & na & Production \\
\hline S-NSF-H14 & 104 & 60 & 104 & Production \\
\hline S-NSF-H15 & 116 & na & na & Production \\
\hline S-NSF-H16 & 315 & 115 & 315 & Production \\
\hline S-NSF-H17 & 180 & 60 & 180 & Production \\
\hline S-NSF-H18 & 98 & 58 & 98 & Production \\
\hline S-NSF-H19 & at LSD & at LSD & at LSD & Spring \\
\hline S-NSF-H26 & 189 & na & na & Production \\
\hline S-NSF-H27 & 26 & na & na & Production \\
\hline S-NSF-H28 & 102 & na & na & Production \\
\hline S-NSF-H29 & 480 & 80 & 480 & Production \\
\hline S-NSF-H30 & 345 & na & na & Production \\
\hline S-NSF-H31 & 74 & 34 & 74 & Production \\
\hline S-NSF-H32 & 550 & 210 & 550 & Production \\
\hline S-NSF-H33 & 529 & 389 & 529 & Production \\
\hline S-NSF-H34 & 155 & 40 & 155 & Production \\
\hline S-NSF-H35 & 190 & 40 & 190 & Production \\
\hline S-NSF-H36 & 400 & 180 & 400 & Production \\
\hline S-NSF-H37 & 345 & 20 & 345 & Production \\
\hline
\end{tabular}


Table 1-2. Site construction information for U.S. Geological Survey sampled grid sites and extra site, North San Francisco Bay Shallow Aquifer study unit (NSF-SA), 2012, California Groundwater Ambient Monitoring and Assessment (GAMA) Program Priority Basin Project.-Continued

[GAMA site identification number: S-NSF-H, North San Francisco Bay Shallow Aquifer study unit, Highlands study area site; S-NSF-HU, North San Francisco Bay Shallow Aquifer study unit, Highlands study area extra site; S-NSF-VP, North San Francisco Bay Shallow Aquifer study unit, Valleys and Plains study area site. Other abbreviations: ft, feet; LSD, land-surface datum; na, not available]

\begin{tabular}{|c|c|c|c|c|}
\hline \multirow{2}{*}{$\begin{array}{l}\text { USGS GAMA site } \\
\text { identification number }\end{array}$} & \multicolumn{3}{|c|}{$\begin{array}{c}\text { Site construction information } \\
\text { (ft below LSD') }\end{array}$} & \multirow{2}{*}{ Site type ${ }^{2}$} \\
\hline & $\begin{array}{c}\text { Site depth } \\
\text { (ft below LSD) }\end{array}$ & $\begin{array}{c}\text { Top of screened or open interval } \\
\text { (ft below LSD) }\end{array}$ & $\begin{array}{l}\text { Bottom of screened or open interval } \\
\text { ( } \mathrm{ft} \text { below LSD) }\end{array}$ & \\
\hline \multicolumn{5}{|c|}{ North San Francisco Bay Shallow Aquifer study-unit grid sites-Continued } \\
\hline S-NSF-H38 & 275 & 200 & 275 & Production \\
\hline S-NSF-H39 & 620 & 420 & 620 & Production \\
\hline S-NSF-H40 & 175 & 40 & 175 & Production \\
\hline S-NSF-HU30 & 47 & na & na & Production \\
\hline S-NSF-VP01 & 64 & 24 & 64 & Production \\
\hline S-NSF-VP02 & 80 & 40 & 80 & Production \\
\hline S-NSF-VP03 & 87 & 27 & 87 & Production \\
\hline S-NSF-VP04 & 217 & 204 & 214 & Production \\
\hline S-NSF-VP05 & 160 & 140 & 160 & Production \\
\hline S-NSF-VP06 & 90 & 30 & 90 & Production \\
\hline S-NSF-VP07 & 360 & 100 & 360 & Production \\
\hline S-NSF-VP08 & 147 & 107 & 147 & Production \\
\hline S-NSF-VP09 & 200 & 40 & 200 & Production \\
\hline S-NSF-VP10 & 134 & 74 & 134 & Production \\
\hline S-NSF-VP11 & 183 & 0 & 20 & Production \\
\hline S-NSF-VP12 & 280 & 100 & 280 & Production \\
\hline S-NSF-VP13 & 620 & 440 & 620 & Production \\
\hline S-NSF-VP14 & 68 & 60 & 68 & Production \\
\hline S-NSF-VP15 & 80 & 38 & 44 & Unused \\
\hline S-NSF-VP16 & 107 & 87 & 107 & Production \\
\hline S-NSF-VP17 & 50 & 20 & 50 & Production \\
\hline S-NSF-VP18 & 28 & 8 & 28 & Production \\
\hline S-NSF-VP19 & 200 & 60 & 200 & Production \\
\hline S-NSF-VP20 & 157 & 57 & 157 & Production \\
\hline S-NSF-VP21 & 755 & 395 & 755 & Production \\
\hline S-NSF-VP22 & 250 & 90 & 250 & Production \\
\hline S-NSF-VP23 & 500 & 80 & 500 & Production \\
\hline S-NSF-VP24 & 210 & 95 & 205 & Production \\
\hline S-NSF-VP25 & 80 & na & na & Production \\
\hline S-NSF-VP26 & 150 & 40 & 150 & Production \\
\hline S-NSF-VP27 & 190 & 30 & 190 & Production \\
\hline S-NSF-VP28 & 255 & 77 & 255 & Production \\
\hline S-NSF-VP29 & 455 & 180 & 455 & Production \\
\hline S-NSF-VP30 & 410 & 60 & 410 & Production \\
\hline
\end{tabular}

${ }^{1}$ Land-surface datum (LSD) is a datum plane that is approximately at land surface at each site. The elevation of the LSD is described in feet above the North American Vertical Datum 1988 (NAVD 88).

${ }^{2}$ Production sites had installed pumps that brought groundwater to the surface; springs had groundwater reaching the surface without pumps. 
Table 1-3. Tritium and carbon-14 data and groundwater age class, North San Francisco Bay Shallow Aquifer study unit (NSF-SA), 2012, California Groundwater Ambient Monitoring and Assessment (GAMA) Program Priority Basin Project.

[Groundwater age classes were based on tritium and carbon-14 data. Groundwater with tritium $<0.2$ tritium units (TU) and percent modern carbon (pmC) $<88$ was defined as Pre-modern, recharged before 1952. Groundwater with tritium $>0.2$ TU and pmc $>99$ was defined as Modern, recharged after 1952. Groundwater with tritium $>0.2 \mathrm{TU}$ and pmc $<99$ or tritium $<0.2$ and pmc $>88$ was defined as Mixed, containing substantial components recharged before and after 1952. GAMA site identification numbers: S-NSF-H, North San Francisco Bay Shallow Aquifer study unit, Highlands study area site; S-NSF-HU, North San Francisco Bay Shallow Aquifer study unit, Highlands study area extra site; S-NSF-VP, North San Francisco Bay Shallow Aquifer study unit, Valleys and Plains study area site. Abbreviations: ${ }^{14} \mathrm{C}$, carbon-14; TU, tritium units; USGS, U.S. Geological Survey; <, less than; >, greater than; - , not detected]

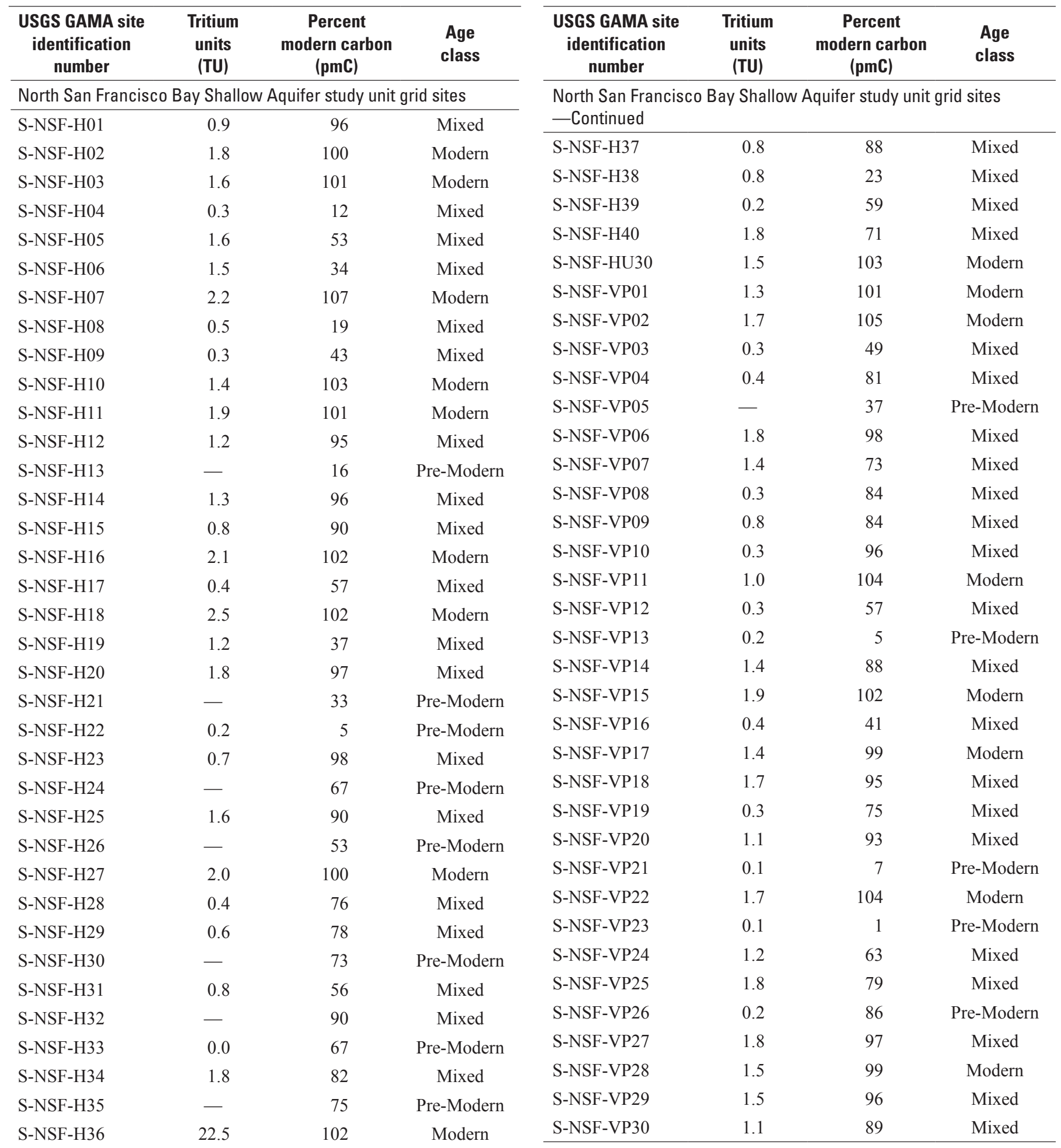


Table 1-4. Oxidation-reduction class, dissolved oxygen concentration, and pH for U.S. Geological Survey (USGS) grid sites and the USGS extra site, North San Francisco Bay Shallow Aquifer study unit (NSF-SA), 2012, California Groundwater Ambient Monitoring and Assessment (GAMA) Program Priority Basin Project.

[GAMA site identification numbers: S-NSF-H, North San Francisco Bay Shallow Aquifer study unit, Highlands study area site; S-NSF-HU, North San Francisco Bay Shallow Aquifer study unit, Highlands study area extra site; S-NSF-VP, North San Francisco Bay Shallow Aquifer study unit, Valleys and Plains study area site. Abbreviations: $\mathrm{mg} / \mathrm{L}$, milligram per liter; na, not available; $<$, less than]

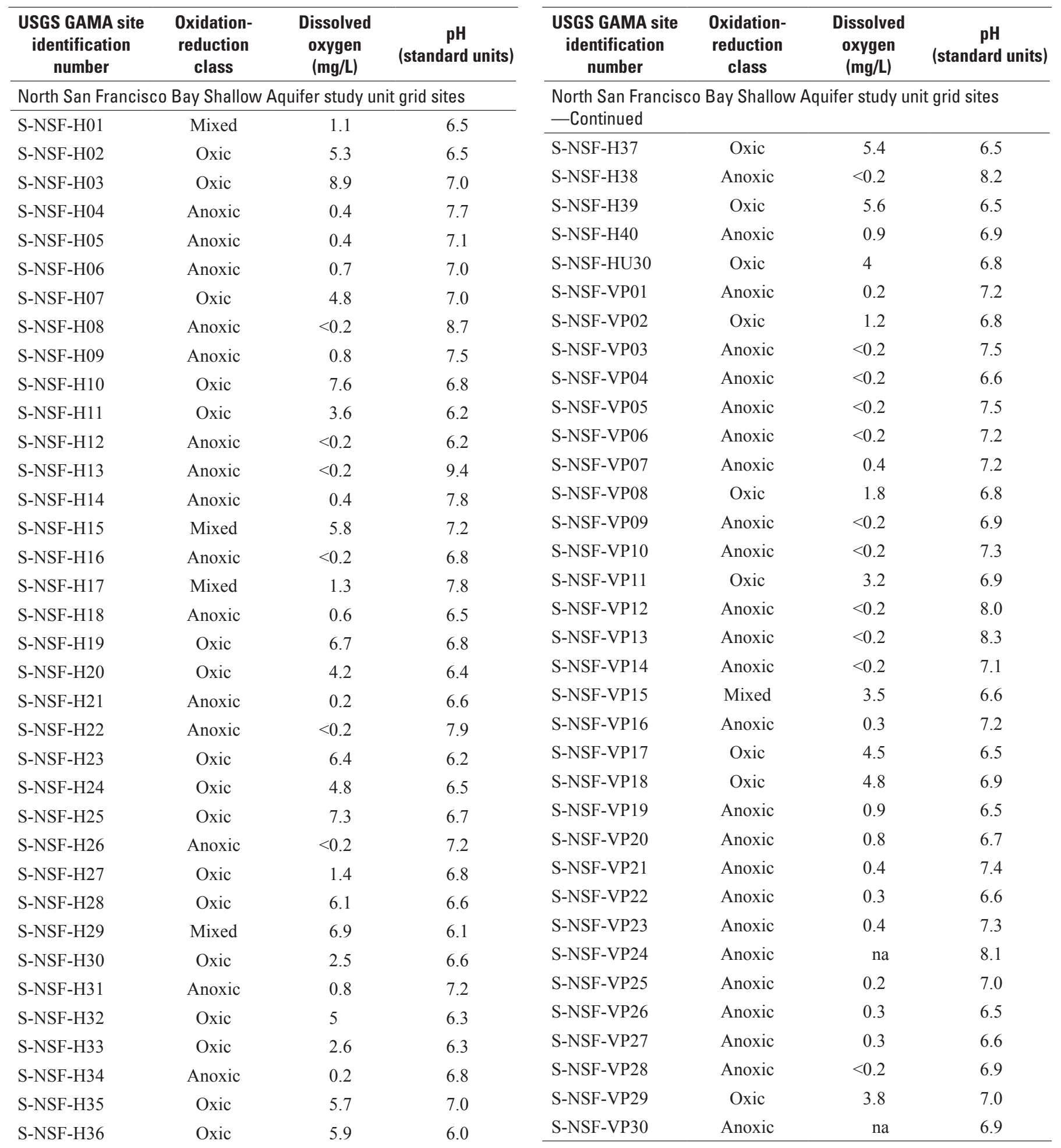


Table 1-5. Oxidation-reduction classification system applied to U.S. Geological Survey (USGS) grid sites and the USGS extra site, North San Francisco Bay Shallow Aquifer study unit (NSF-SA), 2012, California Groundwater Ambient Monitoring and Assessment (GAMA) Program Priority Basin Project.

[Anoxic subclasses: Fe-red, iron-reducing; Mn-red, manganese-reducing; $\mathrm{NO}_{3}$-red, nitrate-reducing. Abbreviations: $\mathrm{mg} / \mathrm{L}$, milligrams per liter; $\mu \mathrm{g} / \mathrm{L}$, micrograms per liter; $\geq$, greater than or equal to; $<$, less than]

\begin{tabular}{|c|c|c|c|c|c|}
\hline Category & $\begin{array}{c}\text { Number } \\
\text { of } \\
\text { samples }\end{array}$ & $\begin{array}{c}\text { Dissolved } \\
\text { oxygen } \\
\text { (mg/L) }\end{array}$ & $\begin{array}{l}\text { Nitrate, as } \\
\text { nitrogen } \\
\text { (mg/L) }\end{array}$ & $\begin{array}{c}\text { Manganese } \\
(\mu \mathrm{g} / \mathrm{L})\end{array}$ & $\begin{array}{c}\text { Iron } \\
(\mu \mathrm{g} / \mathrm{L})\end{array}$ \\
\hline \multicolumn{6}{|c|}{ Oxic classes } \\
\hline Oxic & 26 & $\geq 1$ & any & $<50$ & $<100$ \\
\hline \multicolumn{6}{|c|}{ Anoxic classes } \\
\hline Suboxic & 15 & $<1$ & $<0.5$ & $<50$ & $<100$ \\
\hline $\mathrm{NO}_{3}$-red & 4 & $<1$ & $\geq 0.5$ & $<50$ & $<100$ \\
\hline $\begin{array}{l}\mathrm{NO}_{3} \text {-red, } \\
\text { Mn-red }\end{array}$ & 2 & $<1$ & $\geq 0.5$ & $\geq 50$ & $<100$ \\
\hline $\begin{array}{l}\mathrm{NO}_{3} \text {-red, } \\
\text { Fe-red }\end{array}$ & 1 & $<1$ & $\geq 0.5$ & $<50$ & $\geq 100$ \\
\hline Mn-red & 6 & $<1$ & $<0.5$ & $\geq 50$ & $<100$ \\
\hline $\begin{array}{l}\text { Mn-red, } \\
\text { Fe-red }\end{array}$ & 12 & $<1$ & $<0.5$ & $\geq 50$ & $\geq 100$ \\
\hline \multicolumn{6}{|c|}{ Mixed classes } \\
\hline $\begin{array}{l}\text { Mixed } \\
\quad \text { (oxic - } \\
\text { anoxic, } \\
\text { Mn-red, } \\
\text { Fe-red) }\end{array}$ & 5 & $\geq 1$ & $<0.5$ & $\geq 50$ & $\geq 100$ \\
\hline
\end{tabular}


Publishing support provided by the U.S. Geological Survey Science Publishing Network, Sacramento Publishing Service Center

For more information concerning the research in this report, contact the Director, California Water Science Center U.S. Geological Survey 6000 J Street, Placer Hall Sacramento, California 95819 http://ca.water.usgs.gov 


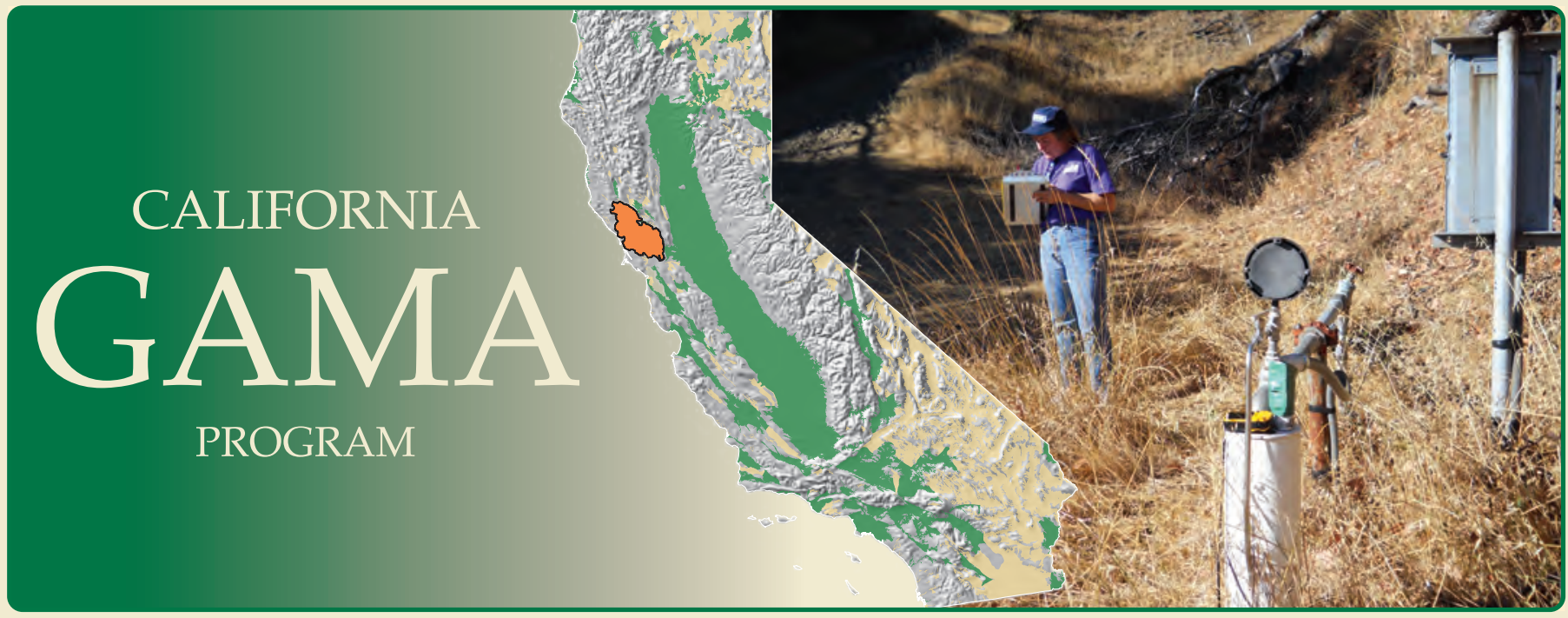

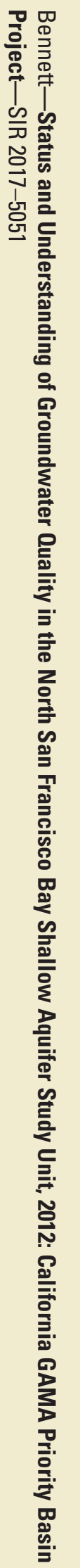

